\title{
How Amsterdam Got Fiat Money
}

Stephen Quinn and William Roberds

Working Paper 2010-17

December 2010

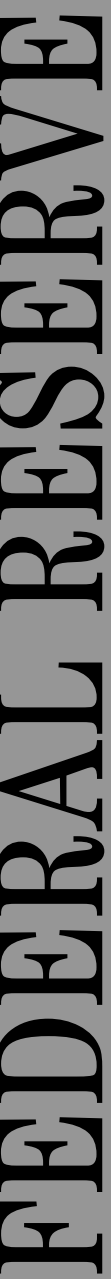




\title{
How Amsterdam Got Fiat Money
}

\section{Stephen Quinn and William Roberds}

\section{Working Paper 2010-17 \\ December 2010}

\begin{abstract}
We investigate a fiat money system introduced by the Bank of Amsterdam in 1683. Using data from the Amsterdam Municipal Archives, we partially reconstruct changes in the bank's balance sheet from 1666 through 1702. Our calculations show that the Bank of Amsterdam, founded in 1609, was engaged in two archetypal central bank activities-lending and open market operations-both before and after its adoption of a fiat standard. After 1683, the bank was able to conduct more regular and aggressive policy interventions, from a virtually nonexistent capital base. The bank's successful experimentation with a fiat standard foreshadows later developments in the history of central banking.
\end{abstract}

JEL classification: E42, E58, N13

Key words: Bank of Amsterdam, fiat money, commodity money, monetary policy, credit policy

The authors thank John McCusker for sharing agio data, Lodwijk Petram for sharing the Deutz folios, and Albert Scheffers for help with the balance books. Also, for comments on earlier drafts the authors are grateful to Christiaan van Bochove, Pit Dehing, Marc Flandreau, Oscar Gelderblom, Joost Jonker, and Charles Sawyer as well as participants in seminars at the University of Alabama, the Bank of Canada, the Federal Reserve Banks of Chicago and New York, and Rutgers University. They are also indebted to Michelle Sloan for many hours of skilled data encoding. Generous research and travel support was provided by the Federal Reserve Bank of Atlanta and Texas Christian University. The views expressed here are the authors' and not necessarily those of the Federal Reserve Bank of Atlanta or the Federal Reserve System. Any remaining errors are the authors' responsibility.

Please address questions regarding content to William Roberds, Research Department, Federal Reserve Bank of Atlanta, 1000 Peachtree Street, N.E., Atlanta, GA 30309-4470, 404-498-8970, william.roberds@atl.frb.org, or Stephen Quinn, Department of Economics, Box 298510, Texas Christian University, Forth Worth, TX 76129, 817-257-6234, s.quinn@tcu.edu.

Federal Reserve Bank of Atlanta working papers, including revised versions, are available on the Atlanta Fed's Web site at frbatlanta.org/pubs/WP/. Use the WebScriber Service at frbatlanta.org to receive e-mail notifications about new papers. 
This version: December 7, 2010

\title{
How Amsterdam got Fiat Money ${ }^{1}$
}

\author{
Stephen Quinn, Texas Christian University \\ William Roberds, Federal Reserve Bank of Atlanta
}

Abstract: We investigate a fiat money system introduced by the Bank of Amsterdam in 1683 . Using data from the Amsterdam Municipal Archives, we partially reconstruct changes in the bank's balance sheet from 1666 through 1702. Our calculations show that the Bank of Amsterdam, founded in 1609, was engaged in two archetypal central bank activities-lending and open market operations - both before and after its adoption of a fiat standard. After 1683, the bank was able to conduct more regular and aggressive policy interventions, from a virtually nonexistent capital base. The bank's successful experimentation with a fiat standard foreshadows later developments in the history of central banking.

\footnotetext{
${ }^{1}$ The authors would like to thank John McCusker for sharing agio data, Lodwijk Petram for sharing the Deutz folios, and Albert Scheffers for help with the balance books. Also, for comments on earlier drafts we are grateful to Christiaan van Bochove, Pit Dehing, Marc Flandreau, Oscar Gelderblom, Joost Jonker, and Charles Sawyer, as well as participants in seminars at the University of Alabama, the Bank of Canada, the Federal Reserve Banks of Chicago and New York, and Rutgers University. We are also indebted to Michelle Sloan for many hours of skilled data encoding. Generous research and travel support was provided by the FRB Atlanta and TCU.
} 


\section{Introduction}

Financial innovation consists of doing more (trading) with less (collateral). A key innovation, present in all modern economies, is the use of fiat money - a kind of virtual collateral whose value derives only from the force of law and custom. Conventional wisdom says that fiat money can enhance liquidity through "credit policy" — the directed relaxation of collateral constraints through a central bank's lending operations, and through "monetary policy" - the beneficial manipulation of economic aggregates through variation of the money stock. ${ }^{2}$

Fiat money, and its implications for policy, are usually seen as the twentieth-century developments. This paper analyzes an earlier and less well known experiment with fiat money, undertaken by the Bank of Amsterdam (Amsterdamsche Wisselbank, henceforth AWB or simply "bank"). The Amsterdam experience with fiat money is noteworthy for its originality, its prominence in European financial history, and its compatibility with price stability over a long period (roughly a century: 1680 through 1780). The AWB opened in 1609 as a municipal exchange bank, an institution for facilitating settlement that was common in Early Modern Europe. Our focus is on the period around 1683 when the bank limited its depositors' ability to withdraw coin, and so effectively became a fiat money provider. The fiat money regime remained in place until the bank's collapse in $1795 .^{3}$

The AWB's transition from exchange bank to fiat bank has been described by economic historians (e.g., Mees 1838, van Dillen 1934, Neal 2000, Gillard 2004, van Nieuwkerk 2009), but these contributions do not fully explain the motivation for the transition. If fiat money did indeed lower and smooth the costs of collateral in Amsterdam markets, how were these changes mani-

\footnotetext{
${ }^{2}$ In its pure form credit policy does not change the stock of money; see e.g., King and Goodfriend (1988).

${ }^{3}$ The bank was not fully dissolved until 1819 .
} 
fested and who benefited? To lapse into modern terminology, how did an early central bank alter its monetary and credit policies after limiting the right of withdrawal?

To shed some light, we examine historical data on the AWB. Using ledgers available from the Amsterdam Municipal Archives, we have compiled partial balance sheets, at a daily frequency, for the AWB from 1666 through 1702, a period centered on the fiat money transition. When combined with information from other sources, these data present a revealing picture of the bank's activities.

First, the data clearly show that the fiat money regime facilitated the AWB's lending to a preferred customer, the Dutch East India Company (Vereenigde Ostindische Compagnie or VOC, a government-sponsored enterprise employing approximately 50,000 people during our period of interest). The bank lent to the Company both before and after 1683; but afterward this lending becomes more seasonal and regular in nature. Seasonality means that this lending often does not show up in the annual AWB balance sheets assembled by van Dillen (1925) nor in the annual balance sheets of the VOC assembled by de Korte (1984). Lending was cheaper and less risky for the AWB after 1683 because liquid claims on the bank were limited and chances of a run were ameliorated. Lending activities were extensive but, over the period considered, never exposed the bank to substantial credit risk. We find that the 1683 changes also freed the City of Amsterdam to frequently take the bank's retained earnings from this profitable activity.

Secondly, our analysis indicates that both before and after 1683, the AWB regularly engaged in open market operations. Again, however, the character of this intervention evolves under the fiat regime, as the bank more often chose to "drain funds" by selling off its metal stock. Indirect evidence suggests that an objective of these operations was to smooth short-term fluctuations in the stock of base money. 
To summarize, the data we analyze show that by the time of 1683 transition, the AWB managers had ample experience with both lending and open market operations. The move to fiat money simply allowed for more vigorous pursuit of these same activities. The markets seem to have applauded the change: following the 1683 reorganization, there was widespread agreement that trading had been enhanced by this new, if puzzling, kind of money. Writing in 1767, James Denham-Steuart offered the following explanation:

The bank of Amsterdam pays none in either gold or silver coin, or bullion; consequently it cannot be said, that the florin banco [bank money] is attached to the metals. What is it then which determines its value? I answer, That which it can bring; and what it can bring when turned into gold or silver, shows the proportion of the metals to every other commodity whatsoever at that time: such and such only is the nature of an invariable scale. ${ }^{4}$

The rest of the paper is organized as follows. Section 2 sets the historical stage for the 1683 policy change. Section 3 describes and presents the data. Section 4 offers some interpretations of the data. Section 5 discusses related literature, and Section 6 concludes.

\section{Historical prologue}

For Amsterdam, the original purpose of its exchange bank was to protect commercial creditors from the unreliable commodity money in general circulation. Modest debasement and resultant inflation was ubiquitous in the Early Modern Netherlands, so the AWB was to be an island of debt settlement backed by high-quality coins (Quinn and Roberds 2009b). To support settlement, the bank needed to attract metal deposits, get debtors to internally transfer payments to creditors, and deliver out metal of an assured quality. The Dutch chose to follow the model of Venice's Banco di Rialto and make the AWB an exchange bank that provided only payment and

\footnotetext{
${ }^{4}$ (Steuart 1805, 75-76). For another favorable review of the Dutch monetary system see Adam Smith, Wealth of Nations, Book IV, Chapter 3.
} 
settlement services (Dehing and 't Hart 1997, 45-6). ${ }^{5}$ With no lending, the bank was to cover operating expenses with fees.

Asymmetric rules promoted metal inflows and debt settlement but discouraged metal outflows. On the accommodating side, the AWB had no fees on deposits or internal transfers. ${ }^{6}$ Also, one could present the AWB with precious metal in any form. If a coin had a price assigned by statute, then the bank honored that price. Metal in other forms was valued by precious metal content. And once created, a balance could settle a debt through transfer to the creditor's account. Creditors gained finality and a trusted general collateral claim. Similar to modern large-value payment systems (e.g., Fedwire), the AWB created finality through gross settlement, meaning that the bank payments could credibly be viewed as final because the bank avoided extending credit and never (explicitly) adopted netting of payments. ${ }^{7}$

Withdrawals, in contrast, were costly. The bank was obliged to supply high-quality Dutch coins at official prices, but the bank was allowed to charge a withdrawal fee of up to 2 percent for silver coins and 2.5 percent for gold coins, though under normal conditions, fees averaged 1.5 percent or less (Van Dillen 1964a, 348; see also Table 2 below). The fees compensated the bank for minting costs and helped cover operating expenses. Most important to our story, however, is that the fees discouraged withdrawals. Some uncertainty also existed, for the bank had discretion regarding which of those Dutch coins it offered at withdrawal. If a customer desired a different

\footnotetext{
${ }^{5}$ Unlike later central banks, the AWB did not issue circulating banknotes.

${ }^{6}$ The bank was permitted to charge transfer fees but chose not to until 1683 (van Dillen 1934, 85).

${ }^{7}$ Some qualifications are necessary. The bank cleared payments once every day (Mees 1838, 124-5) so there was in principle scope for multilateral netting at a daily frequency, i.e., the practical seventeenth-century definition of "realtime" gross settlement was probably once per day. Also, an examination of AWB account positions every half year indicates that despite rules to the contrary, some accounts were in an overdraft position during the summer months of peak market activity, particularly before the 1683 transition (Willemsen 2009).
} 
coin, then the bank could charge an additional premium based on its role as a moneychanger. Moneychanger fees of some level were necessary to prevent coin-to-coin arbitrage. ${ }^{8}$

This paper focuses on the consequences of withdrawal structure, yet we stress that the effects of the early AWB's high withdrawal fees varied by customer. Unlike a modern central bank, anyone could open an account, so customers ranged from foreign merchants to financial intermediaries. Among merchants who routinely operated within the bank's internal payment system, fees were a negligible concern, for they did not expect to withdraw balances. Of far greater moment to them was that the city of Amsterdam required all large bills of exchange to be settled at the AWB. The requirement created demand for deposits, for bills of exchange were the primary means of commercial credit. The bank's total balances reached 925,562 guilders after one year (van Dillen 1934, 117), and grew to 8.3 million guilders by 1683, approximately 5 percent of the coin stock of the Dutch Republic (De Vries and van der Woude 1997, 90).9

In contrast, customers who did expect to withdraw specie learned to skip the primary account-to-coin process offered by the bank. One could avoid bank fees by paying for coins outside the bank with free transfer inside the bank. Fee avoidance also meant that potential deposit customers did not bring metal to the bank. By 1650 , the outside market in bank balances had deepened as private bankers, called cashiers, emerged as dealers who specialized in holding AWB balances and various coins (Van Dillen 1964a, 366-7).

The secondary market lived on margins within the bid-ask spread of the AWB's primary coin-account facility, and the expected costs of the primary market were particularly high for short-term deposits. For example, someone who deposited metal and withdrew it one month later at a 1 percent fee had, in effect, borrowed funds at a simple annualized rate of 12 percent. The

\footnotetext{
${ }^{8}$ Arbitrage is discussed in more detail in Section 4.

${ }^{9}$ The guilder, also known as the florin, was the unit of account in the Dutch Republic. At the time of the AWB's founding, the guilder did not correspond to an actual coin in circulation.
} 
AWB was thus an expensive place to "park" specie. Relative costs fell with time, and long-term participants in the Amsterdam payment system, like cashier-bankers, could recoup these "borrowing" costs through their secondary market operations. As a result, the short-term metal market stayed outside the bank, and little metal routinely flowed in or out of the bank. Instead, deposits waited for periods of cheap metal and withdrawals for expensive metal.

\subsection{Lending}

Lending was the first major deviation from the bank's original plan. The bank soon began lending to the city, the province of Holland, the Republic, government sponsored entities like the VOC, and select individuals such as mint masters and officers of the Admiralty (Van Dillen 1934, 94-100). ${ }^{10}$ After a turbulent half century, however, the bank limited new lending to Amsterdam and the VOC. Table 1 gives the bank's balance sheet at the end of January 1669. The bank's metal-to-deposit ratio is 74 percent. While not a reckless position, the bank needed to be mindful of the threat of a run.

\section{Table 1. Bank of Amsterdam Balance Sheet as of January 31, 1669}

(Millions of Bank Guilders)

\section{Assets}

4.5 Metal

2.1 Loan to Amsterdam

0.2 Loan to Holland

1.1 Loan to VOC

7.9 Total

\section{Liabilities}

6.1 Deposits

1.8 Capital

7.9 Total

Source: Amsterdam Municipal Archives, 5077-1314.

\footnotetext{
${ }^{10}$ The bank's lending activities were widely rumored, but the bank did not publicly acknowledge these until much
} later. See, e.g., Steuart $(1805,403)$. 
Indeed, the French invasion of the Dutch Republic triggered a run in June 1672, during which (our calculations find) the bank lost 34 percent of its balances in two weeks. ${ }^{11}$ Both the Province of Holland and the VOC suspended debt payments, ${ }^{12}$ but the bank successfully passed this test, partly because withdrawal fees had kept the large yet volatile short-term specie flows out of the bank. The absence of "hot money" directly reduced the scale of the run and spared the bank the adverse signals produced by the sudden flight of short-term capital.

Evidence also suggests that the bank adjusted fees to affect withdrawal rates, for the bank raised fees in 1672 and kept them high for years afterward. Average fees can be estimated from the ratio of the bank's non-interest revenues as a percentage of total withdrawals from 1666 to 1681; these ratios are reported in Table 2. The calculation is possible because the bank reported its revenue for these years. ${ }^{13}$ From total revenue, we subtract interest from loans to get a numerator that is an imperfect proxy for fee revenue because we do not know the extent of nonwithdrawal revenue from sources like overdraft fees, bullion trading, etc., so we cannot explain what loss adjustment created an outlier like the 1676 observation. The denominator we have constructed from the AWB's ledgers, and we are missing complete withdrawal information for three of the years. Peering through noise and missing years, fees rose in 1671 as war fears and withdrawals mounted, fees jumped in 1672 with the panic, and fees remained high until at least 1675.

\footnotetext{
${ }^{11}$ On June 14, 1672, the AWB's total balances were 7.6 million guilders. Balances had fallen to 5.0 million by June 30 with a metal stock at an estimated 4.5 million.

${ }^{12}$ For sovereign debt, see Gelderblom and Jonker $(2010)$. For the VOC, see de Korte $(1984,66)$

${ }^{13}$ After 1683, the AWB reported only profit: revenue less expenses.
} 
Table 2. AWB Non-Interest Revenues as a Percent of Withdrawals

$\begin{array}{cccccccc}1666 & 1667 & 1668 & 1669 & 1670 & 1671 & 1672 & 1673 \\ 0.76 \% & 0.79 \% & 0.84 \% & 0.93 \% & 0.78 \% & 1.24 \% & 2.19 \% & \text { NA } \\ & & & & & & & \\ 1674 & 1675 & 1676 & 1677 & 1678 & 1679 & 1680 & 1681 \\ 1.61 \% & 1.53 \% & 0.13 \% & \text { NA } & 1.00 \% & \text { NA } & 1.00 \% & 1.78 \%\end{array}$

Source: See Appendix A.

\subsection{The Bank Guilder}

The other major deviation from the bank's original scheme requires some background, for it defies conventional expectations, then and now (Quinn and Roberds 2009a). In 1638, the Dutch Republic raised the official price of a coin called the patagon, a coin minted in the neighboring Spanish Netherlands. The invading patagon intentionally contained 4 percent less silver than the domestic rijksdaalder issued by the AWB. The new price put the bank in an unsustainable position, for the 1638 rule said that the bank had to accept patagons at 2.5 guilders each, but the old rules made the bank to offer out rijksdaalders at the same price. After a period of arbitrage losses, the bank switched to giving out patagons at withdrawal - a 4 percent "haircut" for depositors. To then make depositors whole in terms of silver, but still avoid rekindling arbitrage, the AWB decided in 1645 to reduce the price of patagons at the bank by 4 percent, from 2.5 to 2.4 guilders each. So, in the end, a customer received 4 percent more coins per guilder, but each coin held 4 percent less silver.

This ad hoc solution had the unintended effect of creating a separate unit of account for bank funds, the bank guilder, distinct from the current (non-bank) guilder (Quinn and Roberds 2007). How so? The Patagon was worth 2.4 bank guilders inside and 2.5 current guilders out- 
side. ${ }^{14}$ In turn, a secondary market developed between the two units of account. Figure 1 offers before and after schematics. Before 1638, each type of coin had a direct secondary market relationship with the bank that swapped media of exchange: coins for accounts. After 1645, the secondary market focused on exchanging units of account: bank guilders for current guilders. A separate price then traded current guilder accounts at cashier-bankers into coins.

Figure 1. Secondary Market Structure

Pre-1638

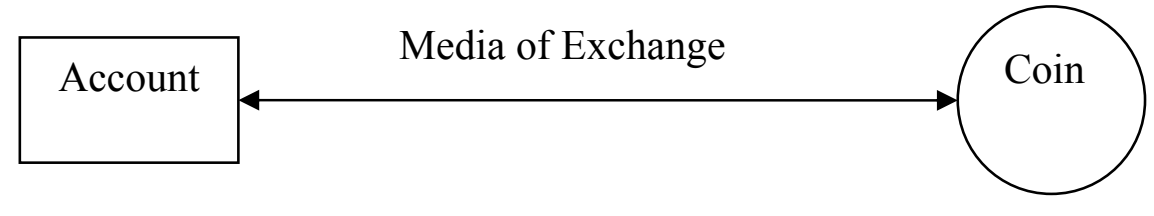

Unit of

Post-1645

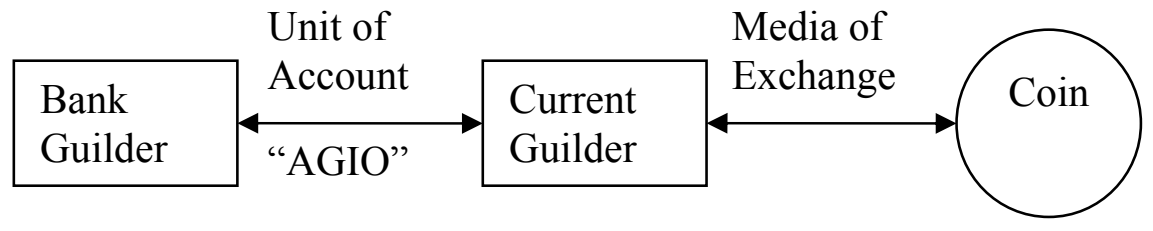

The exchange market between bank guilders and current guilders deepened to become the principal measure of the value of the bank guilder. The exchange rate was called the agio, and the market measured the agio as the premium commanded by bank guilders. If the agio was 3 percent, then 100 bank guilders bought 103 current guilders. To the extent that the metal content of current money changed only slowly after 1659 , the agio can be thought of as a price of bank money in terms of a reference collateral good, i.e. silver. Because of the relatively high withdrawal fees, however, the primary market remained little used.

\footnotetext{
${ }^{14}$ When the Dutch Republic replaced the patagon with domestic coins in its 1659 minting ordinance, the state retained the dual price structure and assigned two silver coins, the dukaat and the rijder, a distinct bank guilder value, current guilder value, and implicit exchange rate. See Table 5.
} 


\subsection{The 1683 restructuring}

The changes of the $1680 \mathrm{~s}$ - the focus of this paper-hinge around the AWB introducing a new primary withdrawal structure that greatly reduced the asymmetry between deposits and withdrawals. ${ }^{15}$ In 1683 , the bank started to give customers a receipt for the specific coins they deposited. ${ }^{16}$ At withdrawal, the receipt obliged the AWB to return the same coins at the deposit price. Also, the receipt's redemption fee was only $1 / 2$ percent for gold and $1 / 4$ percent for silver. Customers found the receipt's specific claim and low fee far more attractive than the traditional general claim at a high fee. Customers rushed to use the new facility.

The bank also made receipts negotiable, and resale mattered because the pre-existing stock bank guilders did not get receipts, so about 8 million bank guilders had only the right to expensive traditional withdrawal. ${ }^{17}$ For new deposits, the 1683 reform unbundled the traditional deposit contract (in which a depositor receives a transferable claim on the bank, plus an option to withdraw) into two separate contracts: the bank guilder account and the receipt. The receipt's option to withdraw metal lasted six months, but one could renew a receipt for another six months by paying the withdrawal fee. Receipts were especially popular with foreign merchants as a lowcost way of temporarily parking precious metals in Amsterdam, to take advantage of profitable trading opportunities if these presented themselves. Coin could be withdrawn later as necessary, at low cost.

Customers learned to trade for the new withdrawal claim instead of exercise the old claim attached to the account, so demand for traditional withdrawal withered. This circumstance al-

\footnotetext{
${ }^{15}$ The new structure had been suggested by an Amsterdam businessman, Johannes Phoonsen, in a 1676 essay (van Dillen 1921). At this time the bank also began charging both sides of all transfers 0.00025 percent payable at the end of the fiscal year (van Dillen 1934, 85).

${ }^{16}$ The receipt allowed its holder to claim the coin anytime within a six-month period, i.e., the receipt resembled an American call option on a specific type of coin, or put option on bank funds.

${ }^{17}$ Legally, new deposits became repurchase agreements between the depositor and AWB (van Dillen 1964b, 395).
} 
lowed the AWB to quietly limit the right to traditional withdrawal sometime in the $1680 \mathrm{~s} .{ }^{18}$ This is when the bank guilder transformed into quasi-fiat money in that one had a right to withdraw metal only if one had a receipt. The stock of bank guilders split into commodity-backed receipts and what Mees (1838) terms an "irredeemable coin of account"-fiat money.

Amsterdam's acquiescence to fiat money seems to follow from customers no longer expecting to use traditional withdrawal except during a run on the AWB. We stress that attentive customers could perceive themselves gaining more than they lost. After the introduction of receipts, the option to withdraw the old way was "in the money" only during a run, yet exercising traditional withdrawal created large runs. Eliminating the individually superior yet collectively dangerous strategy (traditional withdrawal) left a feasible limit on the extent of a run (the stock of receipts), so giving up the option made individuals better off, as long as others also relinquished their option. In the tight-knit world of Dutch political economy, such collective understandings were not uncommon. For example, provincial governments repeatedly but informally suspended sovereign debt payments during crises with little creditor outcry (Gelderblom and Jonker 2010).

Of course, reducing the threat of runs created new incentives for the AWB that customers might not have foreseen; these are described below. Finally, moving to receipts and away from traditional withdrawal also meant abandoning the AWB's original symbiosis with Dutch coins. That separation, however, had already begun in 1680 when the Dutch Republic introduced the gulden: a silver coin worth one current guilder. The gulden set a new standard for the Republic's basic circulating coin, but that standard had no official price at the AWB. The absence of statu-

\footnotetext{
${ }^{18}$ Exactly when redeemability was abolished is unknown. To quote van Dillen $(1934,101)$ : "to that great change no ordinance nor any precise date can be assigned." Indirect evidence, described in Section 4, indicates that redeemability had been de facto abolished by 1685 .
} 
tory bank-to-current guilder exchange rate freed the bank's hands to influence the market agio through its policies.

\section{Data}

Researchers interested in the activities of modern central banks have access to copious amounts of data. The Federal Reserve System, for example, publishes its balance sheet on a weekly basis (the H.4.1 release) and publishes daily data on the market price of its liabilities (the effective fed funds rate). Some studies have even examined records of individual transactions over central banks' payment systems (for Fedwire, see e.g., Bartolini et al. 2008; Furfine 1999, 2001, 2003, 2006; McAndrews and Potter 2002; McAndrews and Rajan 2000) to analyze money market activity. Almost incredibly, much of this same information is preserved for the Bank of Amsterdam. This section introduces the data used in our investigations. ${ }^{19}$

Turning first to balance sheet data, complete balance sheets for the AWB (totaling both assets and liabilities) are only available at a yearly frequency. ${ }^{20}$ However, the ledgers of the bank, available at the Amsterdam Municipal Archives, record every transaction in AWB funds over a given period, so we use the ledgers to reconstruct daily time series of movements in bank liabilities, i.e., changes in aggregate stock of AWB money. Money creation (e.g., deposits) and destruction (withdrawals) is recorded on ledgers of a bank master account. ${ }^{21}$ Similarly detailed records of the bank's metallic assets and some determinants of capital (fee revenues, expenses, and open market profits) have not survived for our period of interest, but some assumptions allow us to construct monthly capital-to-asset ratios in line with known annual figures.

\footnotetext{
19 The data are described in detail in Appendix A.

${ }^{20}$ These were calculated at the end of every January when the bank was closed to reconcile accounts. See Van Dillen (1925).

${ }^{21}$ The Specie Kamer or "coin room."
} 
Loan assets can be reconstructed at the daily level. Lending to the East India Company in particular is easily detected using a "Furfine algorithm": VOC loans appear as large debit entries to the bank's master account (credits to the VOC), for large sums in round numbers, and (principal) repayments as similar credit entries. ${ }^{22}$ Potential open market operations are more problematic. A given debit entry to the bank's master account, for example, may represent an open market purchase, or simply a deposit. Still, we can identify some likely episodes of open market interventions with the help of a second Furfine algorithm, described below.

With the loss of most early ledgers, a reasonably continuous series of extant ledgers only begins in 1666, so our data set starts then. We end in 1702 to capture 35 years of activity surrounding 1683 . We focus only on transactions that change the stock of bank guilders. Even so, we have encoded 20,000 individual master account debit transactions (those that created bank guilders through the deposit of metal, purchase of metal, or new lending). Credit transactions (withdrawals, sales, or loan repayments) produced 17,000 individual transactions. To gain visual clarity and compatibility with the agio data, data have been aggregated into monthly observations: levels being the start of a month and flows being month finish less month start. 420 monthly observations are available over the sample period of 444 months. ${ }^{23}$

Available price data are less complete, but nonetheless extensive. The time series we use is a set of monthly (presumably, average) observations on the market price of bank money (i.e., the agio), spliced together from two sources. The first is an augmented and unpublished version of the agio series in McCusker (1978), generously provided to us by John McCusker. The second is from the records of Joseph Deutz, a prominent Amsterdam merchant, available at the Amsterdam

\footnotetext{
${ }^{22}$ A nearly identical method, pioneered by Furfine (1999), has been used by researchers to filter interbank loan transactions from modern large-value payment system data (e.g., fed funds transactions from Fedwire data).

${ }^{23}$ Six half-years are missing out of the 70 half-years covered here. Missing periods are February-July 1673, February-July 1677, September 1682-January 1683, August 1684-January 1685, September 1697-January 1698, and September 1700-Janurary 1701.
} 
Municipal Archives. ${ }^{24}$ The McCusker data cover our whole period, while the Deutz data run from 1662 to 1688 . Combining the two data sources yields 290 monthly observations. For some of our econometric exercises (e.g., VARs), the agio series was interpolated to a full sample using a related series, the London price of Amsterdam bills reported in McCusker (1978). ${ }^{25}$

Agios are quoted in sixteenths of a guilder, attesting to the liquidity of the market for bank funds. A sixteenth of a guilder also represented the typical profit margin for a cashier on a bank money trade (Steuart 1805, 405).

\subsection{Balances and the Agio}

The basic data on quantity (AWB balances) and price (agio) are presented in figures 2 and 3. The gaps in the balance series follow from time's decimation of records. Also, to focus on the routine, figure 3 truncates the very low agio values observed during the 1672 French invasion and very high agio observations in $1693 .{ }^{26}$ Interpolated values of the agio are shown as dotted lines in figure 3. Vertical lines in the charts mark the initiation of the receipt system.

\footnotetext{
${ }^{24}$ Amsterdam Municipal Archives inventory numbers 234 / 290 through 295.

${ }^{25}$ See Appendix A for the details of the interpolation.

${ }^{26}$ The early 1693 spike in the agio resulted from a widely anticipated, legally mandated devaluation of two coins, the schelling and the 28-stuiver, that had become severely debased (Mees 1838, 113-114). The coins circulated as current money but were not eligible for deposit at the AWB. The devaluations were for 7 and 8 percent respectively, causing the agio to temporarily run as high as 13 percent (the usual 5 percent premium of bank money above current money plus the amount of the anticipated devaluation).
} 
Figure 2: Monthly AWB balances 1666:2-1703:2

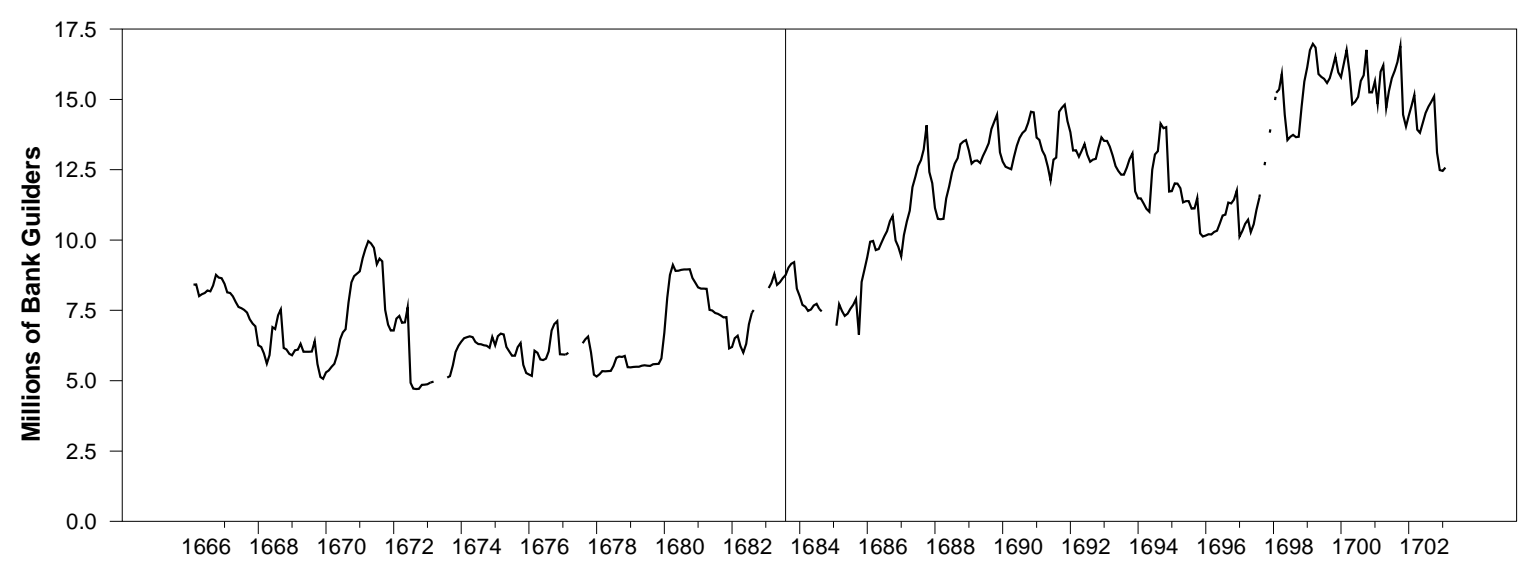

Source: See Appendix A.

Figure 3. Agio, by month, 1666:2-1703:2

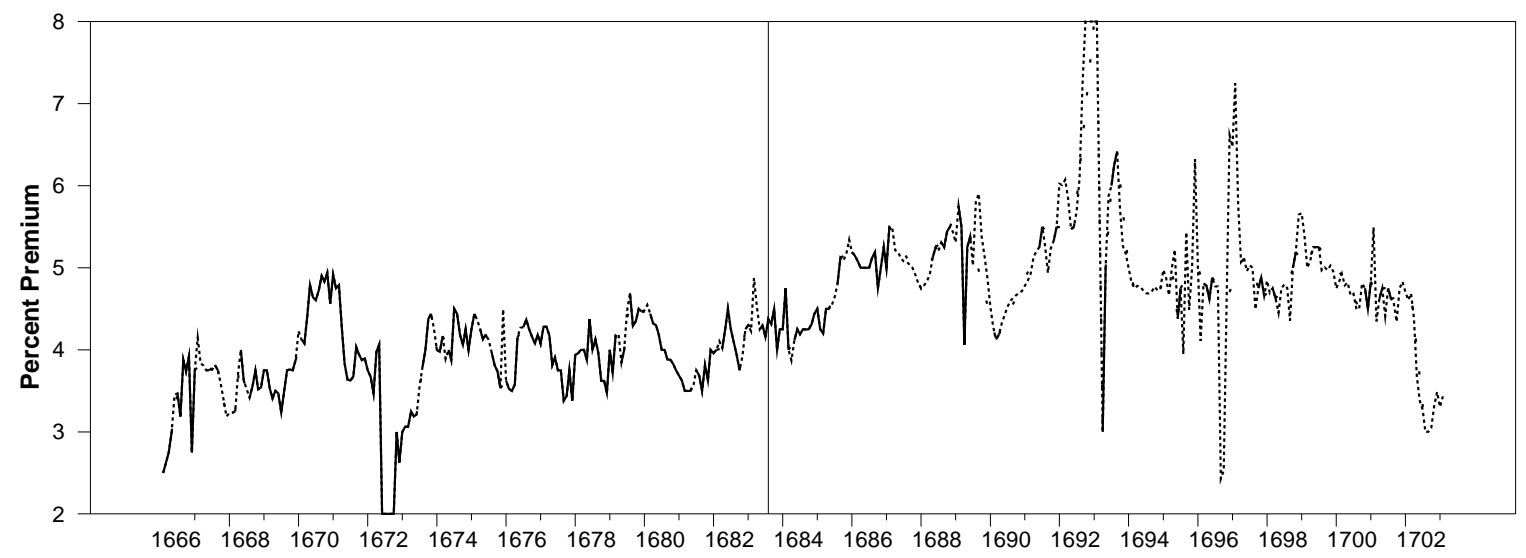

Source: See Appendix A.

\subsection{The AWB's uses of funds}

The first step in analyzing the asset side of the bank's balance sheet was to strip out VOC loan balances using the procedure mentioned earlier. These are shown in Figure 4. 
Figure 4. VOC loan balances (principal) by month, 1666:2-1703:2

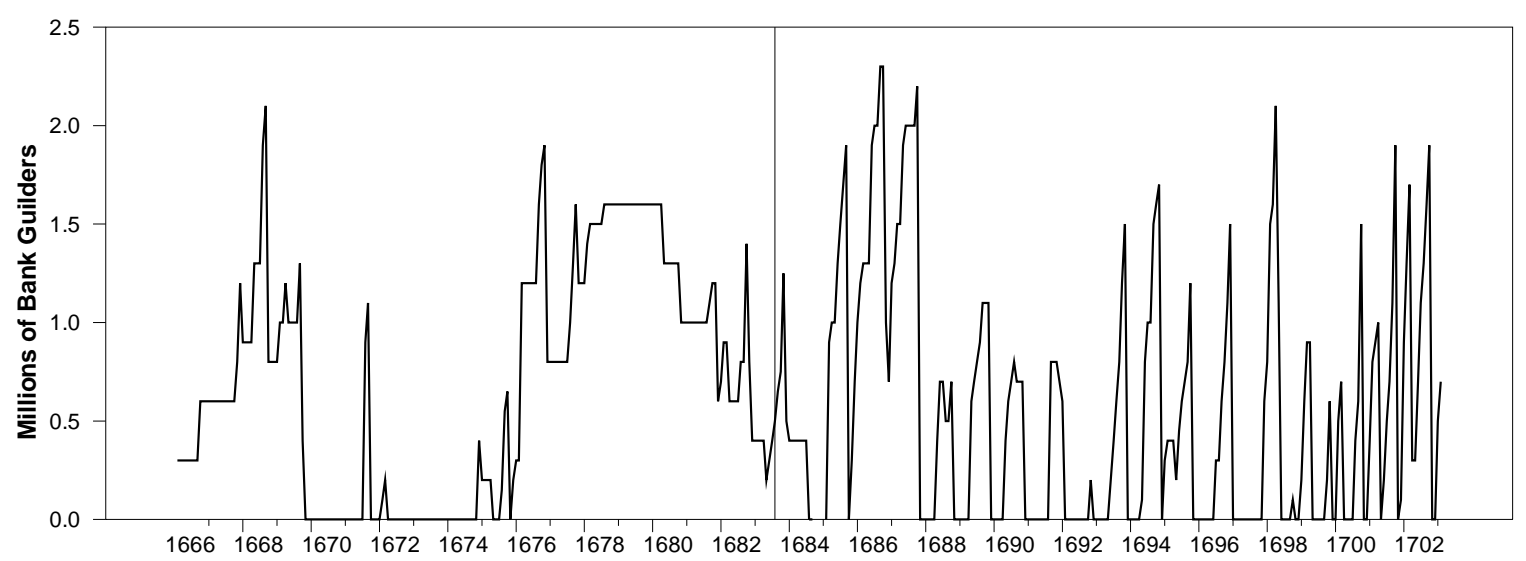

Source: See Appendix A.

Lending to the VOC was an important activity of the bank, both before and after 1683 (Uittenbogaard, 2009). The Amsterdam city council authorized a credit line of 1.7 million in 1682 (Mees 1838, 196), but figure 4 shows that this limit had already been breached in practice. The peak level of VOC indebtedness does not increase after 1683, but the data clearly show that multi-year bank credit to the VOC fell away after 1683 while short-term trough-to-peaks grew.

The data challenges are more severe for non-VOC uses of funds. Bank records say nothing about what collateral changed hands when bank guilders were created or destroyed, but the bank did use different accounting channels for different types of transactions. We have identified one channel for coin deposits and another channel for bullion purchases. Essentially, coin deposits are routed through the accounts of the bank's clerical staff, while purchases (i.e., sales of balances) appear directly as debit entries to the bank's master account (see Appendix A for details).

Metal sales by the bank (purchases of balances) do not have a distinct accounting channel, so these sales are (somewhat more tentatively) proxied using another Furfine algorithm: round guilder transactions are assigned as "coin withdrawals" and transactions with fractional amounts to "bullion sales." We describe coins as being deposited and withdrawn because the bank was obliged to accept and return official coins at ordinance prices. Recall that the withdrawal contract 
was defined in terms of official coin prices and that altering such prices undermined the collateral structure of all balances. In contrast, the bank had latitude regarding bullion (including nonofficial coins, metal wire, etc.), and the bank routinely violated what restrictions had been placed on the buying and selling of bullion (van Dillen 1934, 92-3).

Based on this sorting of transactions, much of the increase in balances after 1683 came through more coin deposits. And, as would follow from lower withdrawal fees, there were also more coin withdrawals. Figure 5 presents the amount of coin deposits and withdraws by month from February 1666 to January 1703. Inflow and outflow deepened considerably after the regime change. Note that post-1683 inflows roughly mirror outflows, providing some confirmation for the algorithm used to identify coin withdrawals.

Figure 5. Monthly Coin Deposits and Withdrawals, 1666:2 to 1703:2

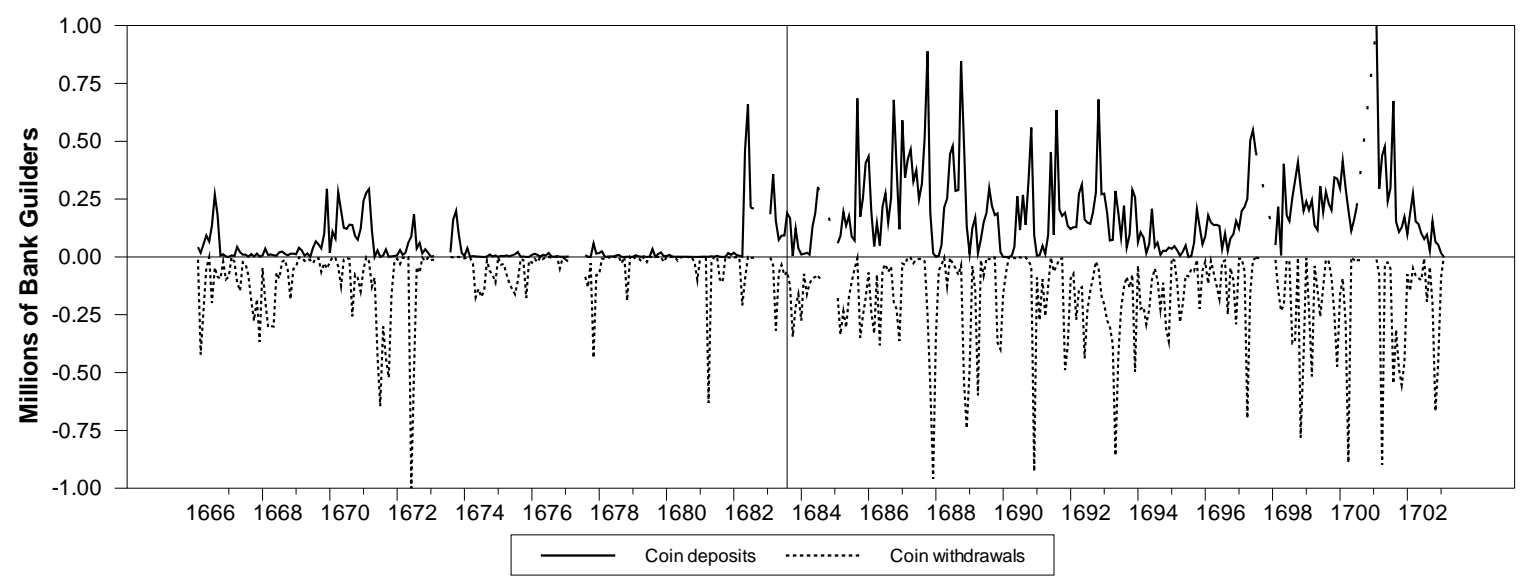

Source: See Appendix A. Note that June 1672 Coin Withdrawals is truncated: the observation's value is $-2,478,372$ bank guilders.

If the fee reduction facilitated withdrawals (and therefore more deposits), it should also have promoted smaller yet more frequent withdrawals. To check this, figure 6 plots annual withdrawal transactions against the average withdrawal size. By drawing a line at 5,000 guilders, one clearly sees that withdrawal transactions jump after 1683: the outlier being the crisis year of 1672 behaving similarly to a typical year under the receipt system. Withdrawal size shows a 
similar pattern with 3 out of 14 early years averaging below 5,000 guilders and 3 out of 15 later years averaging above the same. ${ }^{27}$ The series have a correlation of -0.64 .

Figure 6: Average Size versus Number of Withdrawals, 1666 to 1702

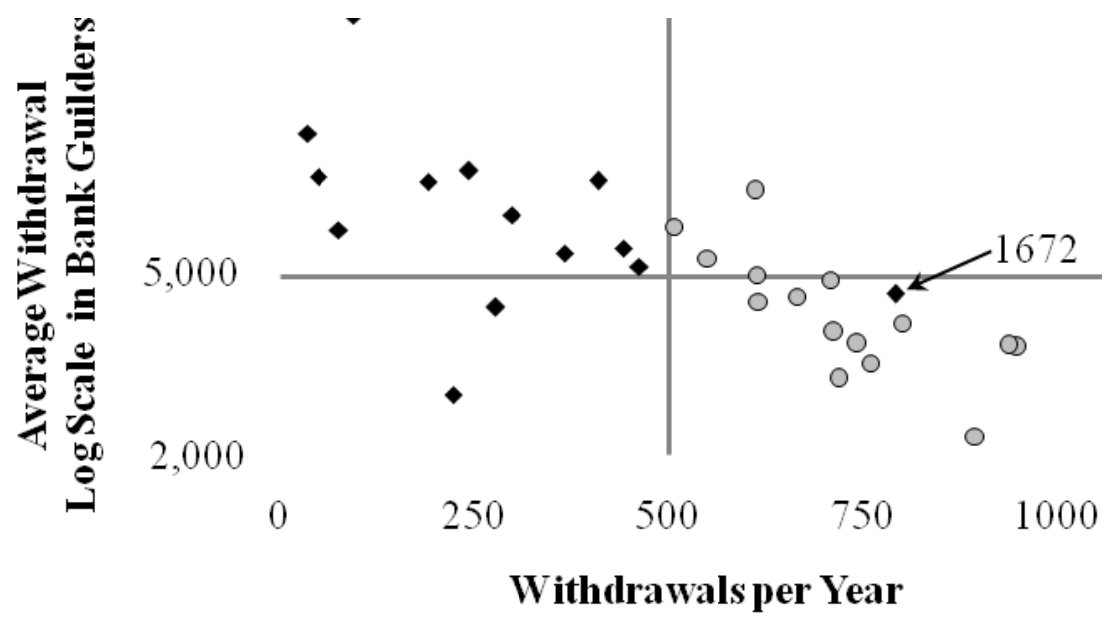

- Up To 1683 o After 1683

The transactions we identify as bullion operations show a different pattern. Figure 7 presents our calculation of bullion purchases and sales by month over our sample period. Total purchases before 1683 (14.6 million) roughly equal purchases after (15.4 million), while total sales doubled from 8.6 million (1666-1682) to 16.7 million (1683-1703). A dramatic aspect of the bullion series is the infrequent spikes that we suspect are large open market operations. There is noticeable asymmetry between sales and purchases: there are 9 months where the AWB purchased more than 700,000 guilders worth of metal, but no months during which the bank sells so much metal.

\footnotetext{
${ }^{27}$ Note that the vertical scale is logged to enhance visual clarity.
} 
Figure 7. Monthly Bullion Purchases and Sales, 1666:2 to 1703:2

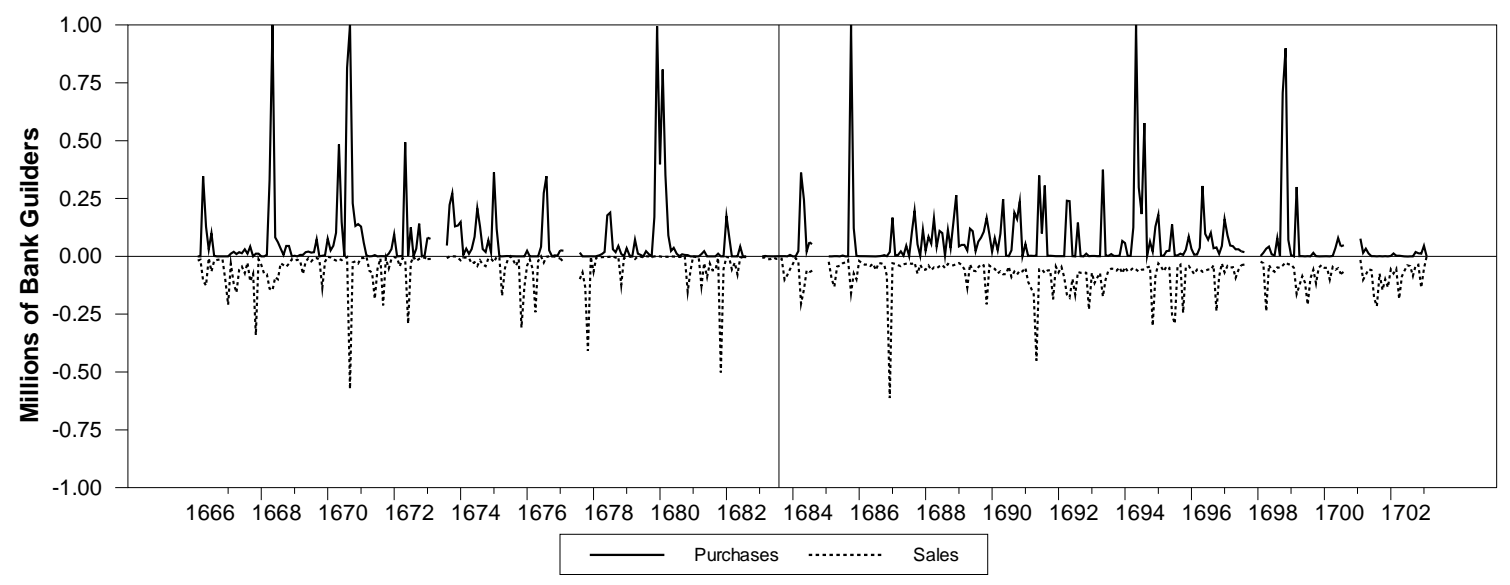

Source: Appendix A.

To finish our partial reconstruction of asset side of the AWB's balance sheet, the series shown in Figures 5 and 7 must be integrated over time to obtain series on cumulated deposits and cumulated purchases. Since there are no initial values for these two component series, some normalizing assumption is required. We conservatively set the bank's February 1666 purchases to zero, and set the initial value for cumulated deposits to be the entire stock of bank balances, excluding VOC loans. The two series are graphed together in Figure 8. The pre-1683 era shows that the stagnation of bank balances involved a long decline in deposits and an offsetting rise in the purchases. ${ }^{28}$ After 1683, deposits were the driving force behind the expansion of bank balances. ${ }^{29}$ The receipt system was a way to arrest the long term decline in deposits. ${ }^{30}$

\footnotetext{
${ }^{28}$ The decline of deposits likely began in the 1650s when the long-term growth in AWB balances ended. Quinn and Roberds (2009a) argues that the stabilization of the monetary system in the 1650s obviated the AWB's original role of protecting creditors from poor coinage, so demand for deposits slackened.

${ }^{29}$ Post-1683, cumulated purchases would approximate "outright purchases" of assets on a modern central bank's balance sheet, while cumulated deposits would (again quite roughly) correspond to "repurchase agreements."

${ }^{30}$ Demand for deposits also revived from instability in coin quality lasting from 1680 to 1693 . See section 4.2.
} 
Figure 8. Cumulated Net Deposits and Bullion Purchases, 1666:2 to 1703:2

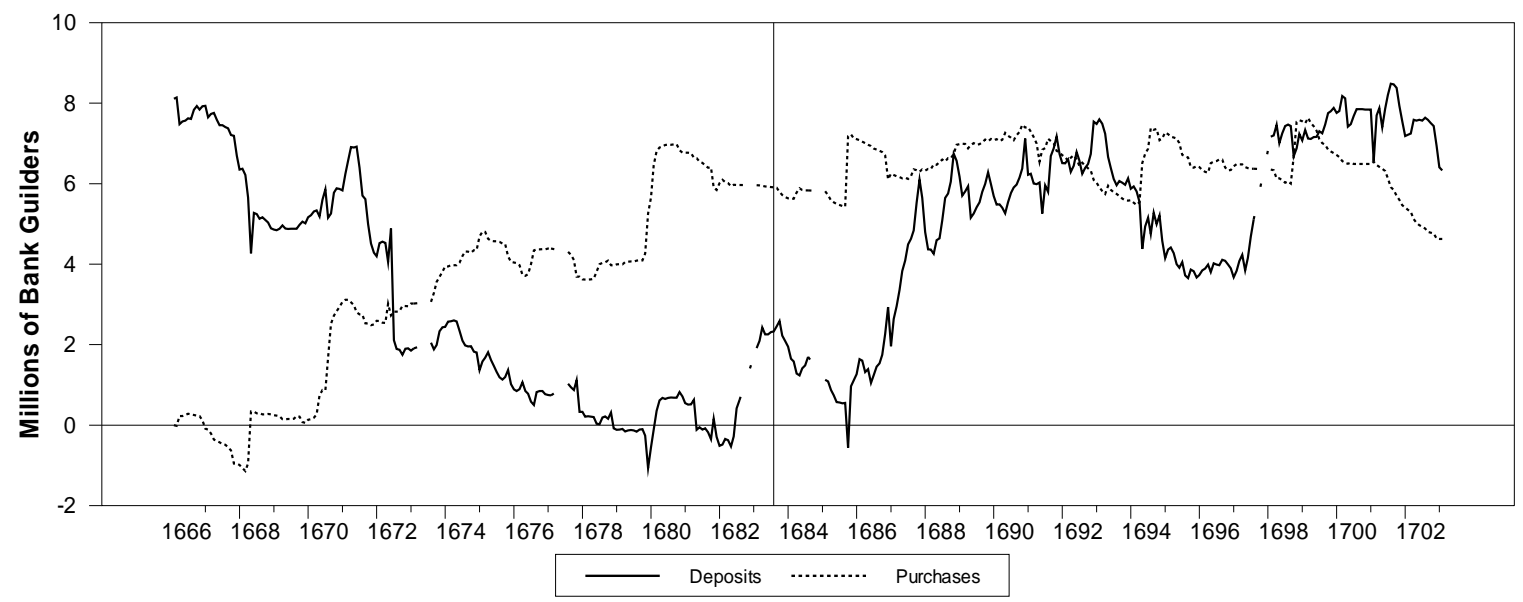

Source: Appendix A.

\subsection{Summary statistics}

Table 3 reports statistics on the data series before and after the 1683 regime change.

Table 3. Statistics on the Agio and AWB Balances

\begin{tabular}{|c|c|c|c|c|c|c|c|}
\hline Series & Sample & $\mu(x)$ & $\sigma(x)$ & $\mu(\Delta x)$ & $\sigma(\Delta x)$ & $K(x)$ & $K(\Delta x)$ \\
\hline \multirow{2}{*}{ Agio (percent) } & $1666: 2-1683: 7$ & 3.89 & 0.458 & 0.007 & 0.256 & \multirow{2}{*}{$5.69^{* *}$} & \multirow{2}{*}{1.04} \\
\hline & $1683: 8-1703: 2$ & 4.83 & 0.530 & 0.067 & 0.407 & & \\
\hline \multirow{2}{*}{$\begin{array}{l}\text { Total balances } \\
\text { (million guilder) }\end{array}$} & $1666: 2-1683: 7$ & 6.79 & 1.29 & -0.006 & 0.413 & \multirow{2}{*}{$8.92^{* *}$} & \multirow{2}{*}{$1.83^{* *}$} \\
\hline & $1683: 8-1703: 2$ & 12.51 & 2.41 & 0.004 & 0.586 & & \\
\hline \multirow{2}{*}{$\begin{array}{l}\text { VOC Loan Princi- } \\
\text { pal }\end{array}$} & $1666: 2-1683: 7$ & .685 & .557 & 0.000 & .231 & \multirow{2}{*}{$1.56^{*}$} & \multirow{2}{*}{$2.62^{* *}$} \\
\hline & $1683: 8-1703: 2$ & .592 & .623 & 0.001 & .474 & & \\
\hline \multirow{2}{*}{ Deposits } & $1666: 2-1683: 7$ & 2.90 & 2.72 & -0.039 & 0.335 & \multirow{2}{*}{$4.48^{* *}$} & \multirow{2}{*}{$1.92^{* *}$} \\
\hline & $1683: 8-1703: 2$ & 5.27 & 2.15 & 0.011 & 0.363 & & \\
\hline \multirow{2}{*}{ Purchases } & $1666: 2-1683: 7$ & 3.20 & 2.31 & 0.031 & 0.196 & \multirow{2}{*}{$8.09^{* *}$} & \multirow{2}{*}{$3.31^{* *}$} \\
\hline & $1683: 8-1703: 2$ & 6.43 & 0.656 & -0.006 & 0.188 & & \\
\hline
\end{tabular}

Source: see Appendix A. Statistics for the agio omit two episodes of outliers: June-October 1672 and JanuaryFebruary 1693. $K$ denotes the nonparametric Kolmogorov-Smirnov test statistic for the null hypothesis of equality of distributions (across subperiods): approximate, two-sided 5 percent and 1 percent critical values for $K$ are 1.36 and 1.63 , respectively. 
The table indicates that after 1683 the agio fluctuated around its approximate statutory level of 5 percent; it also becomes more variable. The distribution of first differences in the agio does not change significantly across samples, i.e., there is no change in "smoothness" of the agio after 1683. Balances increase due to accumulated metal purchases and an influx of deposits. Outstanding loans to the VOC average about the same before and after 1683, but these become less smooth after the reform. Purchases are notably less variable after the 1683 reform.

The empirical literature on the founding of the Federal Reserve (see Section 5) emphasizes changes in seasonal patterns for certain macro series around the time the Fed began operations in 1914. With these results in mind, we conducted three exercises to see whether the AWB's 1683 reform resulted in similar changes. The first exercise was to simply calculate monthly means for the agio and the three monetary component series; these are shown in Figure 9.

Figure 9: Monthly means (percent deviation from annual means)
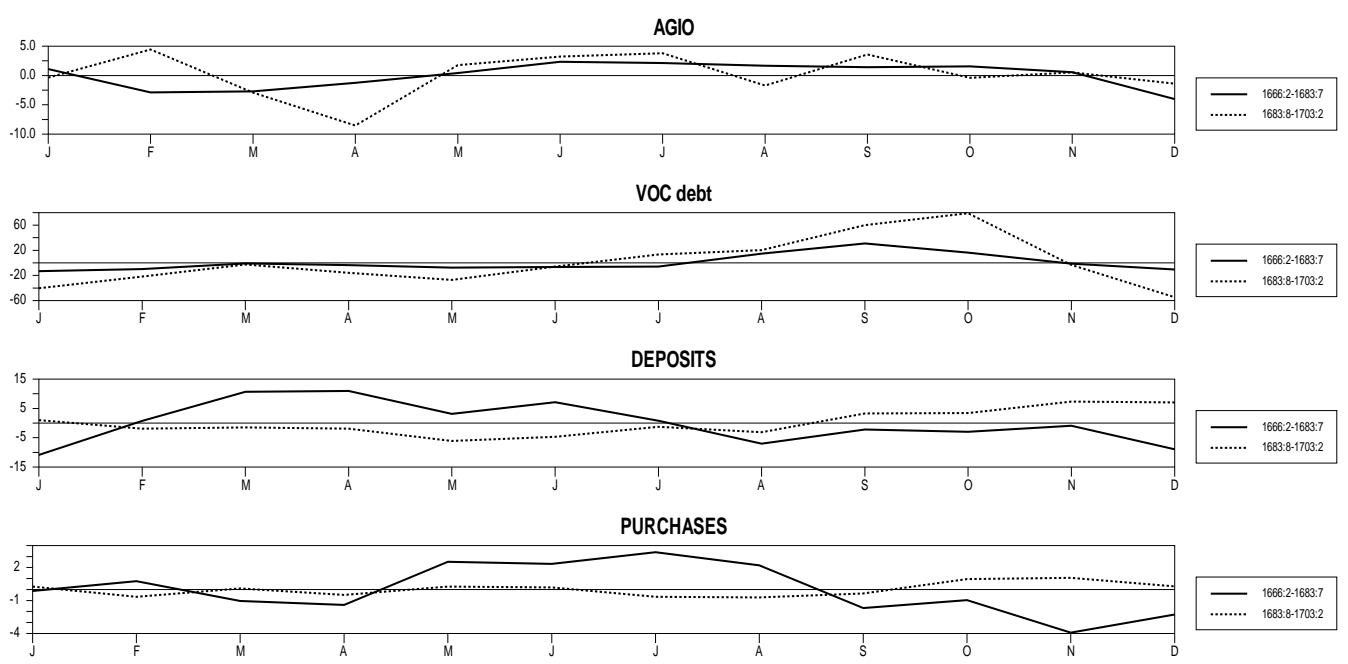

There is little visual evidence of seasonality in the series for the agio and purchases, either before or after 1683. Monthly means for deposits display less seasonality after the regime change, while VOC debt becomes highly seasonal. These patterns were confirmed in a second, more formal exercise, which consisted of performing standard F-tests for the significance of seasonal dum- 
mies in each equation of a VAR model (described in more detail in section 4) for the four series. Deterministic aseasonality is rejected at conventional significance levels for VOC purchases and deposits, but accepted for the agio and purchase series. This pattern holds before and after 1683

The third exercise was to estimate spectra for the four data series in order to check for indeterministic seasonality; these are shown in Figure 10.

Figure 10: Estimated spectral densities (log scales)
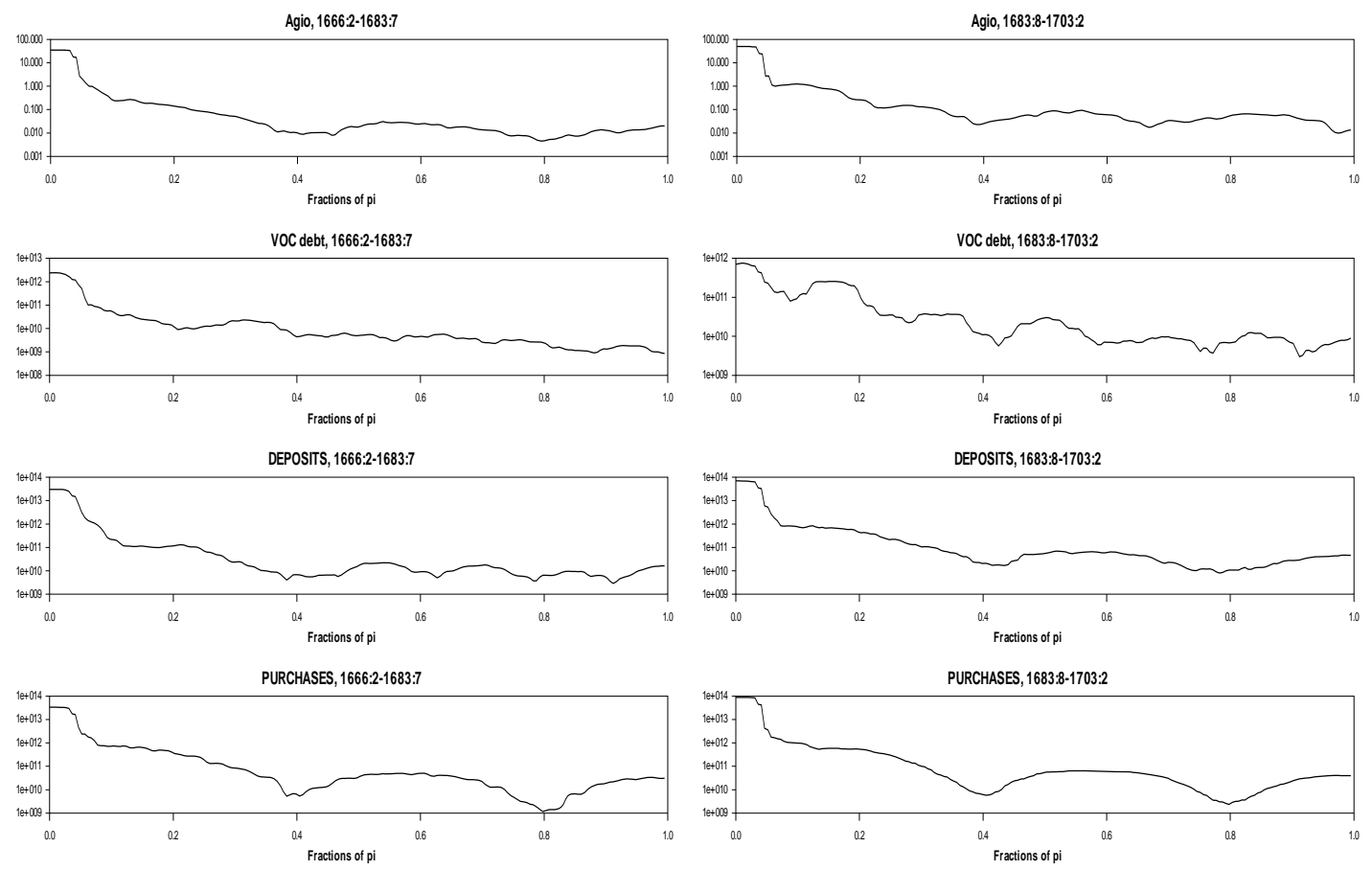

The most striking feature of figure 10 is that the spectrum for VOC balances displays welldefined maxima centered around seasonal frequencies of $\pi / 6, \pi / 3$, and $2 \pi / 3$ (12-month and harmonic cycles), post-1683. Seasonality for the other series is relatively modest and there are no great differences across subsamples.

Summarizing the results of this section, initial exploration of the data suggests that the post-1683 regime was characterized by higher flows and levels of deposits, somewhat less variable purchases, a higher average agio, and more seasonal and regular borrowing on the part of 
the VOC. ${ }^{31}$ The next section investigates to what extent these observed changes can be attributed to changes in policy.

\section{The impact of policy changes}

To market participants at the time, receipts were the only obvious discontinuity in the function of the AWB after 1683. As before, the bank continued to serve as a trusted settlement service provider and as a (surreptitious) financial intermediary to the VOC. Convertibility of deposits was limited, but money could easily be traded for coin on the open market, much as before. Where then were the gains associated with the adoption of a fiat standard?

Our answer, in essence, is that placing restrictions on withdrawals allowed Amsterdam to partly escape the opportunity costs of a system of exchange based on commodity money (e.g., Sargent and Wallace 1983), as compared to a system with either greater availability of credit, or fiat money. To be certain, some amount of commodity money was essential for the functioning of a seventeenth-century open economy. A great entrepôt of its day, Amsterdam was where Europe purchased goods from Asia and other points east with silver unearthed in the Americas (de Vries and van der Woude 1997). Over time, Amsterdam also became the center of the European bullion trade.

However, the data shown in figure 5 indicate that before 1683, the bulk of the metal backing for AWB deposits rarely entered or left at the monthly frequency, so the high cost of withdrawing funds from the bank meant that the principal purpose of this metal was to confer value to the bank guilder. Over the longer term (figure 8), withdrawals outpaced deposits, but the AWB chose to offset this trend with purchases, so overall balances remained stable (figure 3).

\footnotetext{
${ }^{31}$ Available data indicate that the regime change seems to have had virtually no impact on trend inflation. Annual price indices for the Netherlands (van Zanden, 2004) show an average yearly deflation of $0.38 \%$ from 1666 to 1684 and $0.30 \%$ from 1684 to 1702 .
} 
The prospect of seven million guilders' worth of metal simply sitting in the bank's vault must have tempted even the most ardent hard-money advocates. The 1683 reform nudged the AWB's functionality somewhat closer to that of a modern central bank.

\subsection{Credit policy}

The AWB's early lending activities represented a partial shift to an asset-backed currency. As long as all deposits were convertible, however, the bank learned to be reluctant about extending credit much in excess of its capital position. Either the bank exposed itself to the risk of a run by lowering its metal-to-deposit ratio, or it financed lending from its own capital, or a combination of the two. Alternatively, the bank could slacken its liquidity constraints by imposing higher withdrawal fees as it did in 1672 , but this discouraged deposits and imposed costs on market participants. We will now elucidate how the bank lent more frequently with less capital cushion after $1683 .^{32}$ To do so requires a discussion of the bank's relationship with the City of Amsterdam.

The bank's activities as financial intermediary were closely constrained by its relationship with the city. After the VOC, the city was the bank's other major borrower, if borrower is the correct term. ${ }^{33}$ Figure 11 shows the evolution of the city's debt over the sample period. In the early 1650s, the city had borrowed 2 million guilders in metal from its bank, and soon afterwards the city stopped paying interest on the loan and never again paid interest on its debt. Figure 11 shows this debt still on the books in 1666 through 1683. In 1683, the city began taking out more metal, in grey, and occasionally paying some of it back, but these metallic loans did not create

\footnotetext{
${ }^{32}$ See Appendix B for a formal model of the changeover in the bank's credit operations.

${ }^{33}$ The Province of Holland's debt also appears on the AWB's books but never changes during our sample period.
} 
balances. Loans to the city that did create balances are in black, and those loans do not begin to substantially add to AWB balances until December1698. ${ }^{34}$

Figure 11: Amsterdam Loans Outstanding by Month, 1666-1702

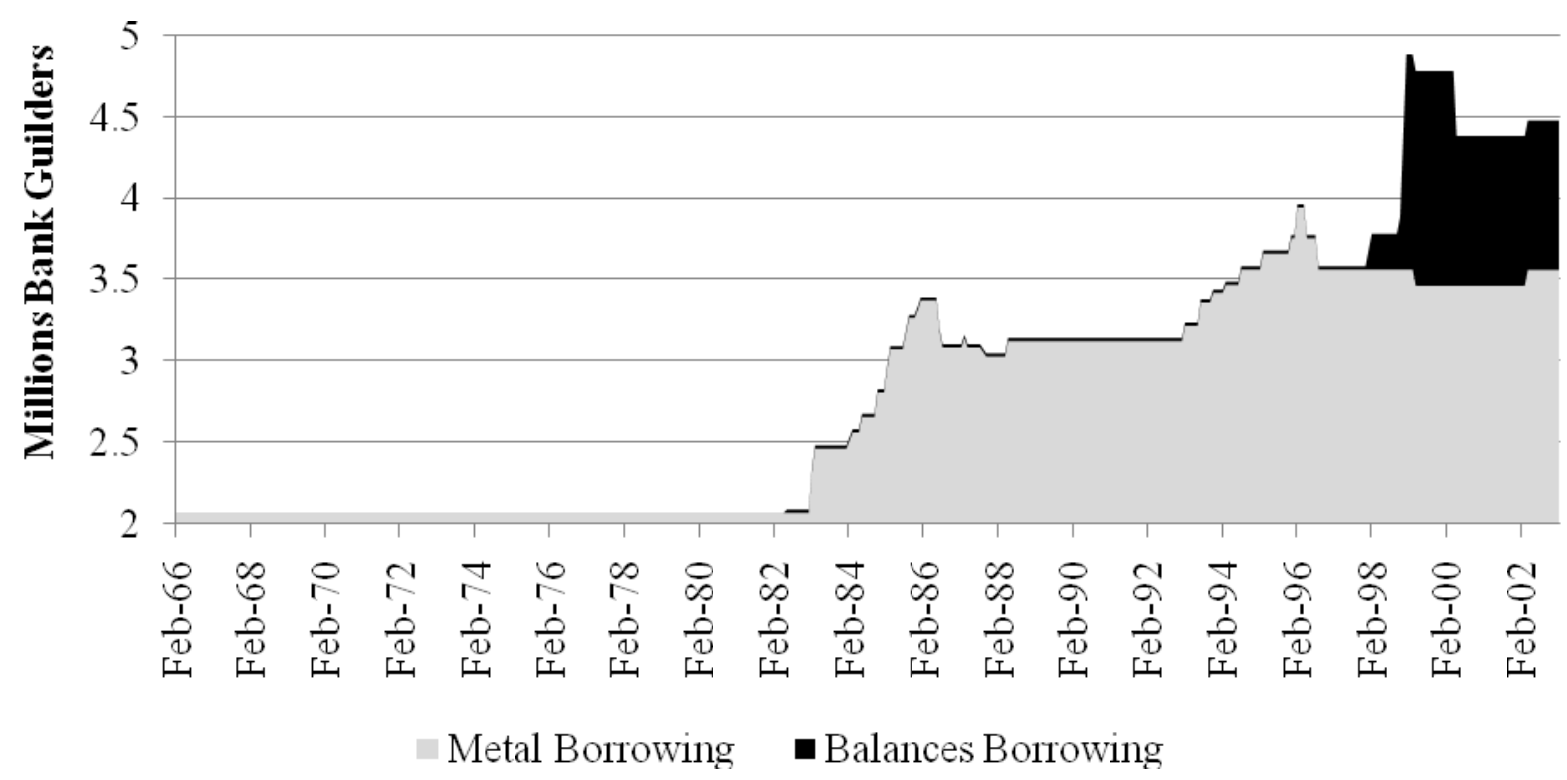

Source: AWB Balance Books, see Appendix A for details.

Amsterdam's impact on the AWB is easily missed because the city booked its removal of metal or balances as loans. The city did not pay interest and eventually wrote off the loans by reducing the bank's capital. This accounting hid periods of negative capital. Figure 12 shows our calculation of the bank's monthly adjusted capital-to-asset ratio over our period. The ratio treats municipal "loans" as capital deductions.

The adjustment shows that the 2 million guilders the bank gave to city in the early $1650 \mathrm{~s}$ (to build a new city hall) put the AWB into a negative position, and it shows that this era ended when the AWB began to grow capital faster than assets after the Crisis of 1672. Negative capital, however, returned after 1683 through the process depicted in figure 11 above. Thereafter, the city took capital during periods of need and then let deposits (figure 8) raise the capital ratio. By

\footnotetext{
${ }^{34}$ A lone 20,000 guilder balance was created in June 1682.
} 
1795 , the city had taken 6.5 million guilders from the bank (our calculation). The only indication of this in the traditional series is the bank's occasional write-off of loans until book capital neared zero: 2.3 million guilders in 1685 and 170,000 guilers in 1691 (Willemsen 2009, 85). Limiting the right of withdrawal allowed the city take metal and the bank admit (at least to itself) to having no capital.

Figure 12. Adjusted Asset Ratios, by Month, 1666 to 1703

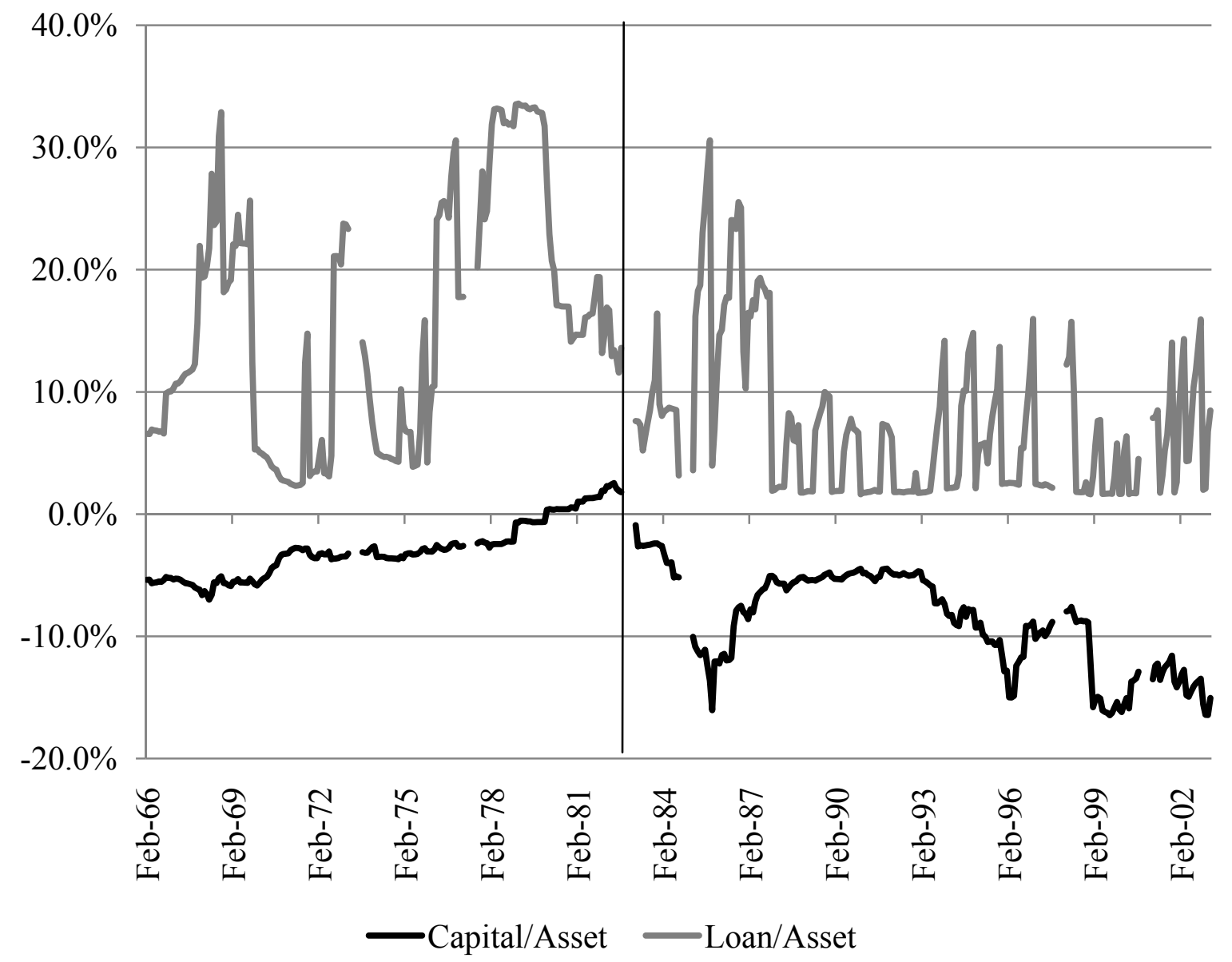

Source: Authors' calculations using van Dillen (1925, 701-97, 971-84) and our data set.

Figure 12 also plots a loan-to-asset ratio which, after removing municipal takings and their subsequent write-offs, leaves mostly variations in VOC borrowing. In the first half of our period, the combination of long-term lending to the VOC and a weak deposit base meant that the AWB's 
monthly loan/asset ratio averaged 16 percent (our calculation). With the regime change, peak lending did not change (figure 4), but the loan/asset ratio declined to a 7 percent average because loans did not linger and because the deposit base grew (figure 8).

The increase in seasonal lending meant that the VOC increased its use of the AWB as a regular supplier of operating credit. The bank was a major lender to the VOC because it enjoyed certain advantages: its perpetual nature, ${ }^{35}$ its political position,${ }^{36}$ and its privileged position in bill settlement. But the VOC also had direct access to the Dutch bond market and averaged a total year-end debt of 10 million current guilders over our sample period. ${ }^{37}$ The strong seasonality, especially after 1683 , suggests that the VOC valued the AWB as an overdraft facility to acquire metal to ship to Asia. ${ }^{38}$

Some confirmation of this can be detected from surviving records of the VOC. De Korte (1984) collected annual VOC balance sheets that give levels at the start of a fiscal year (usually May 31) for assets such as cash, credits, and the inventory of unsold goods; and for liabilities (primarily corporate debt). Better still, three flow variables are also known for the fiscal year: expenditures paid, dividends paid and revenues collected. ${ }^{39}$ An OLS estimation reported in Table 4 calculates how these variables correlate with our dependent variable of interest, the amount the

\footnotetext{
${ }^{35}$ The 1609 charter of the bank contained no "sunset date." This contrasts with say, the First Bank of the United States, which received a 20 -year charter.

${ }^{36}$ During the period we analyze, the AWB was governed by a board of commissioners, comprised of three or four prominent individuals such as former mayors (" $t$ Hart, 2009).

${ }^{37}$ See Appendix A, Table A10.

${ }^{38}$ The regime change of 1683, however, does not explain the end of multi-year lending by the bank to the VOC. That change coincides with structural changes in the VOC's corporate debt following from the crisis of 1672 (de Korte 1984, 66). At the start of our sample, 1666, the VOC's long-term debt was in the form of bonds callable at par by either debtor or creditors. The VOC had a program of retiring long-term debt in 1670 until the crisis in 1672, and the lack of borrowing in Figure 4 for those years is evident. During the 1672 crisis, the VOC suspended the call option, and in the years that followed restructured its debt to avoid this problem. First, the VOC began offering short-term anticipations that gave a senior claim on auction proceeds from the next fleet to arrive. Then the company issued long-term debt without creditor call options. The bubble of multi-year borrowing (figure 4) from 1676 to 1682 appears to have been part of the VOC's debt restructuring.

${ }^{39}$ All are measured in current guilders, and all are for operation in the Netherlands. Ships at sea and operations in Asia are excluded.
} 
VOC borrowed that year from the AWB ${ }^{40}$ Expenditures during a year strongly and positively correlate with borrowing, and suggest a derived demand for AWB loans of 25 percent of VOC expenditures. In contrast, information about that year's sales revenue lacks explanatory power. These results agree with the idea that the VOC was borrowing to outfit ships before the year's fleet returned from Asia, and about half of equipment costs were coins (Korte 1998, 16).

Table 4. VOC Correlates to AWB Lending, 1666 to 1702

Dependent Variable: AWB LENDING in Bank Guilders

Independent Variables in Current Guilders.

\begin{tabular}{lccc}
\hline \hline & Coefficient & $t$-Statistic & $p$-value \\
\hline \hline Flow Variables & & & \\
1. EXPENDITURES & 0.243575 & 2.854951 & 0.0079 \\
2. DIVIDENDS & 0.086721 & 0.588119 & 0.5610 \\
3. SALES & 0.001038 & 0.013216 & 0.9895 \\
& & & \\
Levels at Year-Start & & & \\
4. INVENTORY & -0.057136 & -1.495904 & 0.1455 \\
5. CASH & -0.158387 & -0.823348 & 0.4170 \\
6. CREDIT DUE & -0.402999 & -1.614495 & 0.1172 \\
7. TOTAL DEBT & -0.006557 & -0.141776 & 0.8882 \\
& & & \\
\hline \hline \multicolumn{1}{c}{$\mathrm{N}=36$} & \multicolumn{2}{c}{ Adjusted R-squared } & 0.365084 \\
& \multicolumn{3}{c}{ Durbin-Watson } \\
\hline \hline
\end{tabular}

Source: See Appendix A.

Given the relationship between AWB lending and VOC expenditures, the economic benefit from expanded seasonal lending should have been expanded VOC investment in expeditions. To visually check this, Figure 13 plots for each of our sample years VOC expenditures on the horizontal and AWB lending to the VOC on the vertical. While noisy, more expenditures do seem to follow an expanded credit policy by the AWB: the series' simple correlation is +0.56 . Unfortu-

\footnotetext{
${ }^{40}$ VOC borrowing totals follow the VOC's fiscal year rather than the AWB fiscal year reported in van Dillen (1934, 979-984).
} 
nately we do not know exactly where bank loans fit into the VOC's capital structure, e.g., the seniority of bank loans relative to other kinds of debt. But the VOC's frequent borrowing post1683 suggests that the ready availability of bank credit contributed to the company's ability to manage its cash flows and outfit ships.

Figure 13. AWB Lending and VOC Expenditures, 1666 to 1702

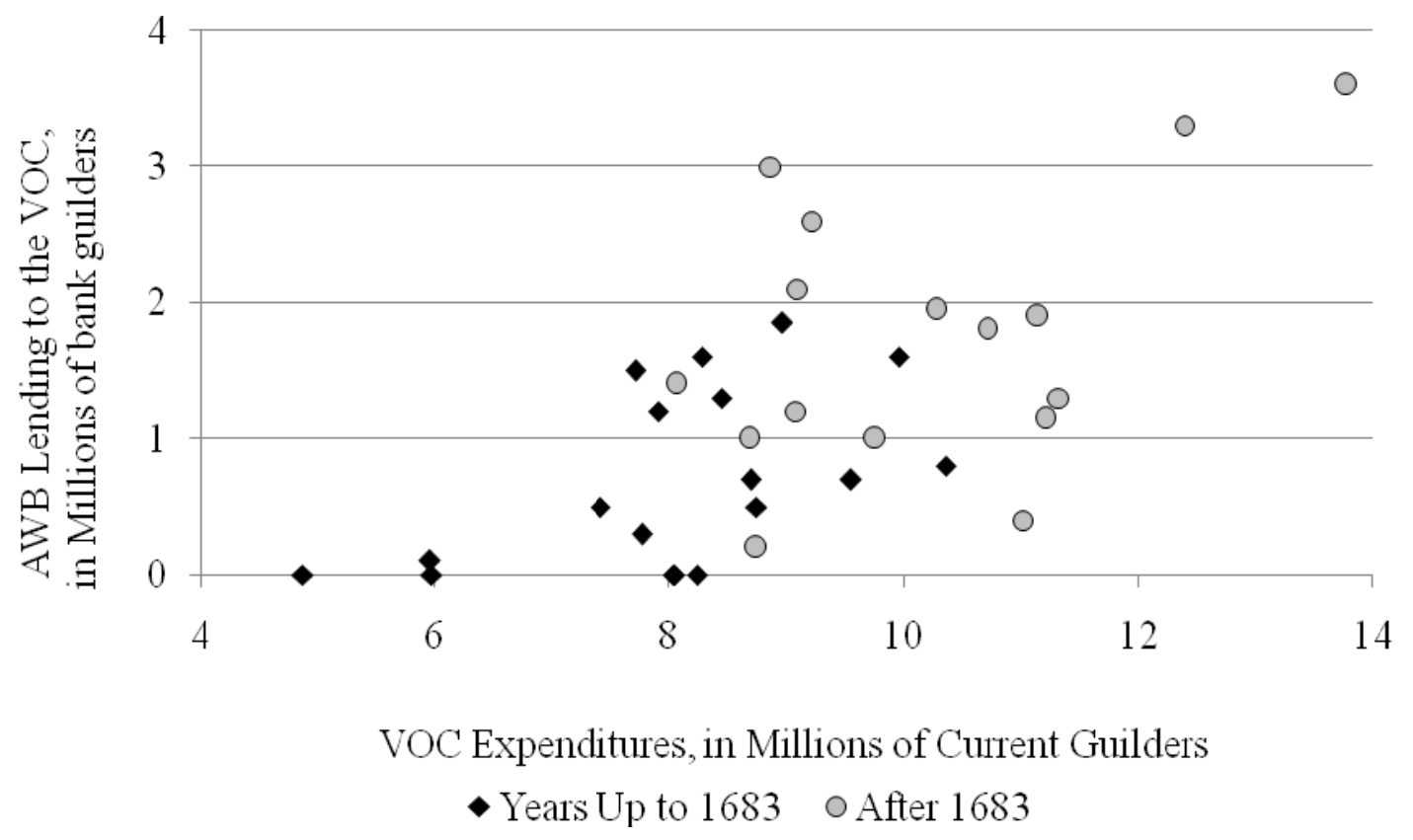

Sources: See Appendix A.

Pulling the elements of this section together, we find that the new regime allowed the bank to expand seasonal lending to the VOC and pay large dividends to the city while slightly reducing its aggressiveness relative to its assets. To see this, returning to figure 12 and consider the vertical distance between the loan/asset ratio and the capital/asset ratio as the bank's overall aggressiveness: the sum of leveraged lending (loans not backed by capital) and capital extraction (liabilities not backed by assets). This spread averaged 18 percent in our sample years before 
receipts (1666 to 1683 ) and 16 percent for our years after (1683 through 1702). The bank could do more with less because of the surge in demand for receipts and fiat bank money.

\subsection{Monetary policy}

The original and overriding policy goal of the Bank of Amsterdam was to maintain a stable value of bank balances - the settlement medium for financial transactions within the city. The pre-1683 monetary regime partially fulfilled this goal by eliminating the inflationary trend that prevailed in the early decades of the seventeenth century. However, a defect of this regime was a persistent "undervaluation" of bank money: high withdrawal fees meant that the market value of the agio could fall as much as $1.5 \%$ below its statutory value before triggering a corrective market response (see figures 3 and 5). Figure 14 plots the empirical density of the agio and indicates that before 1683, its market value rarely approached its statutory level of about 5 percent.

\section{Figure 14. Estimated densities for the agio}

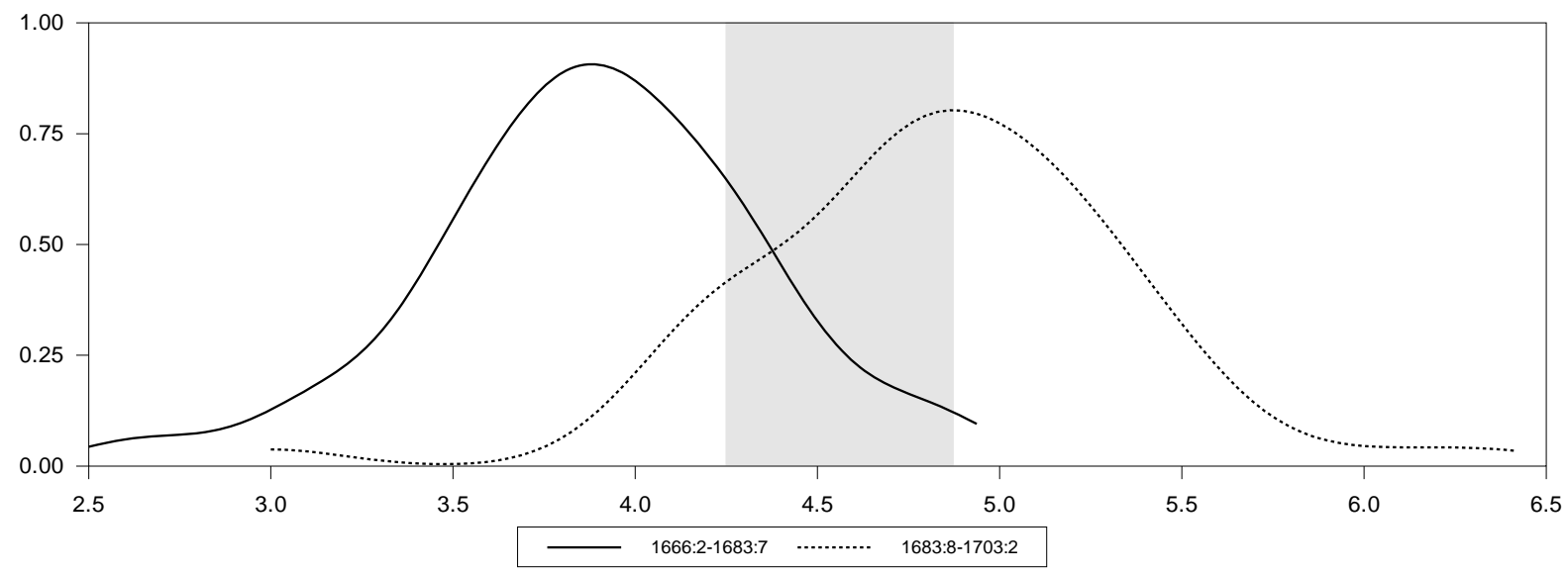

Source: see Appendix A. Estimated densities are histograms, smoothed with Gaussian weights. Outlier values are not shown. Shaded area is the post-1683 target zone suggested by van Dillen (1934).

The post-1683 regime was associated with higher levels of the agio, but it is not clear how much of this change in valuation can be attributed to deliberate policy actions by the bank. Van Dillen's $(1934,102)$ description of the bank's policy is reminiscent of the operations of a modern 
currency board: “... for many years [after 1683], they bought in bank money when the agio fell to 4 1/4 percent and sold whenever it rose to $47 / 8$ percent." As can be seen from figure 14, however, the data are not consistent with a simple "currency board" characterization: most of the time the market agio lies outside its putative target band (shaded). Moreover, there is evidence suggesting that much of the post- 1683 change in the behavior of the agio was simply the result of arbitrage. We now consider this evidence in more detail.

\subsubsection{Agio arbitrage}

To illustrate coin-to-bank money arbitrage, we consider the two coins that anchored the Dutch system of trade coins: the silver dukaat and the silver rijder ${ }^{41}$ Mint data on these coins is reported Polak (1998), and Table 5 gives some basic information for each coin.

Table 5. Implied Agios for Two Silver Trade Coins

\begin{tabular}{|c|c|c|}
\hline & Dukaat & Rijder \\
\hline Statutory Values & & \\
\hline in current guilders & 2.5 & 3.15 \\
\hline in bank guilders & 2.4 & 3.0 \\
\hline & & $5.00 \%$ \\
\hline Implied deposit (statutory) agio $(\alpha)$ & $4.17 \%$ & \\
\hline & & \\
\hline Implied withdrawal agio $\left(\frac{1+\alpha}{1+w}-1\right)$ & & $3.45 \%$ \\
\hline with $w=1.5 \%$ & $2.63 \%$ & $2.44 \%$ \\
\hline $\begin{array}{l}\text { with } w=1.5 \% \text {, and } \\
\text { a rijder } \text {-specific fee of } 1 \%\end{array}$ & & $4.74 \%$ \\
\hline with $w=0.25 \%$ & $3.91 \%$ & \\
\hline
\end{tabular}

Source: Polak (1998, 73-4).

The mint ordinance assigned two values to each coin. ${ }^{42}$ The ratio of the current guilder value over the bank guilder value (less 1) gives the implied statutory agio $\alpha$ for each coin. If the

\footnotetext{
${ }^{41}$ We emphasize that many other types of coin were deposited in the bank, especially after the introduction of receipts.
} 
bank charges $w>0$ at withdrawal, then the (steady-state) market agio $a$ should lie in the inter$\mathrm{val}^{43}$

$$
(\underline{a}, \bar{a}) \equiv\left(\frac{1+\alpha}{1+w}-1, \alpha\right)
$$

if the coin is to reside in the bank. Table 5 reports the upper and lower steady-state boundaries for each coin assuming $w=1.5 \%$. A market agio above 4.17 would encourage the deposit of dukaten, an agio below 3.45 would encourage the withdrawal of rijders, and an agio in between would create no arbitrage incentives. Recall also that the AWB could assess an additional fee on popular coins at withdrawal, so an additional premium could reduce the rijder's lower bound to match the dukaat's lower bound. Thus, for the pre-1683 period, the two-coin steady-state interval (intersection of the single-coin intervals) would have been $(\underline{\alpha}=2.5 \% ; \bar{\alpha}=4.17 \%)$. Figure 14 shows that the agio rarely fell below the lower bound during this period, but often moved beyond the upper bound. The agio distribution shifts rightward after 1683, but its overall shape and upper-bound violations were retained. Let us consider why the distribution changed in this fashion.

\subsubsection{Agio mean}

The 1683 reduction in fees forced a change in the agio's steady-state equilibrium. A fee of 0.25 percent (the new standard for silver coins) caused each coin's arbitrage bounds to tighten. Returning to the dukaat and the rijder (table 5), no market agio now existed at which both coins could remain free of arbitrage pressures. For example, an agio of 4.5 would encourage the deposit of dukaten (pushing down the agio) and the withdrawal of rijders (pushing up the agio). Low fees pushed a corner solution: either the agio would settle around 4 percent when the AWB

\footnotetext{
${ }^{42}$ Ordinances also assigned each coin a metal content that could affect the steady state properties of the agio, but this issue does not pertain when the price of silver is within a coin's mint equivalent and mint price. For a full analysis, see appendix $\mathrm{C}$.

${ }^{43}$ After 1683, the cost of a withdrawal would include the market value of a receipt. Hence in practice the agio could fall slightly below the lower endpoint in (1) without violating no-arbitrage.
} 
ran out of rijders or it would settle around 5 percent when the stock of circulating coins ran out of dukaten.

The post-1683 density of agio in figure 14 shows that higher range predominated. We cannot say if the AWB intended for the lower fees to push the agio to a new center, but the bank did accept the new reality. For example, in January 1687, the AWB switched the agio it used for internal record keeping from 4.25 to $5 .{ }^{44}$ Similarly, for the three-gulden, a coin very similar to the rijder, the AWB chose an agio of 5.26 percent. $^{45}$

The shift to a higher agio is surprising at first glance, for the transition period began with no rijder receipts and no arbitrage incentive to create them. Indeed, the agio remained around 4 percent until 1685 . The answer is to also note that the new regime created an increased demand for deposits, but mint ordinances favored the production of rijders. ${ }^{46}$ The two coins had the same official mint price, but rijders had a seigniorage rate of 1 percent while the dukaat's rate was 0.2 percent. $^{47}$

To see that profits mattered, figure 15 plots the production of dukaten and rijders by the six Dutch provincial mints from the introduction of the two coins in 1659 to the advent of receipts in $1683 .^{48}$ It shows rijder production outpacing dukaat by 2 to 1. Dukaat production is largely limited to the introductory period just after $1659^{49}$ and a surge in emergency minting (much of it by the government) during 1672 and 1673. The rijder also sees emergency minting in 1673.

\footnotetext{
${ }^{44}$ Amsterdam Municipal Archives inventory number 5077/1322, f. 9.

${ }^{45}$ The AWB recorded 3-gulden coins at 2.85 bank guilders (AMA 5077/1322, f. 43).

${ }^{46}$ With a low mint equivalent, dukaten were also favored for export.

${ }^{47}$ As of the 1668 mint ordinance, both coins had a mint price of 24.873 guilders per mark (Polak 1998, 174-5). The mint equivalents were 24.933 for the dukaat and 25.131 for the rijder.

48 The series does not capture all Dutch mint production, and incorporates smoothing of some multi-year production figures, so it is more indicative than exhaustive.

${ }^{49}$ From 1659 to 1668 , the dukaat was subsidized in that in that the States General taxed rijder production at 0.158 guilders per mark and dukaat production at 0.026 guilders per mark (Polak 1998, 174-5). This tax ended in 1688 .
} 
Figure 15. Annualized Production at Provincial Mints

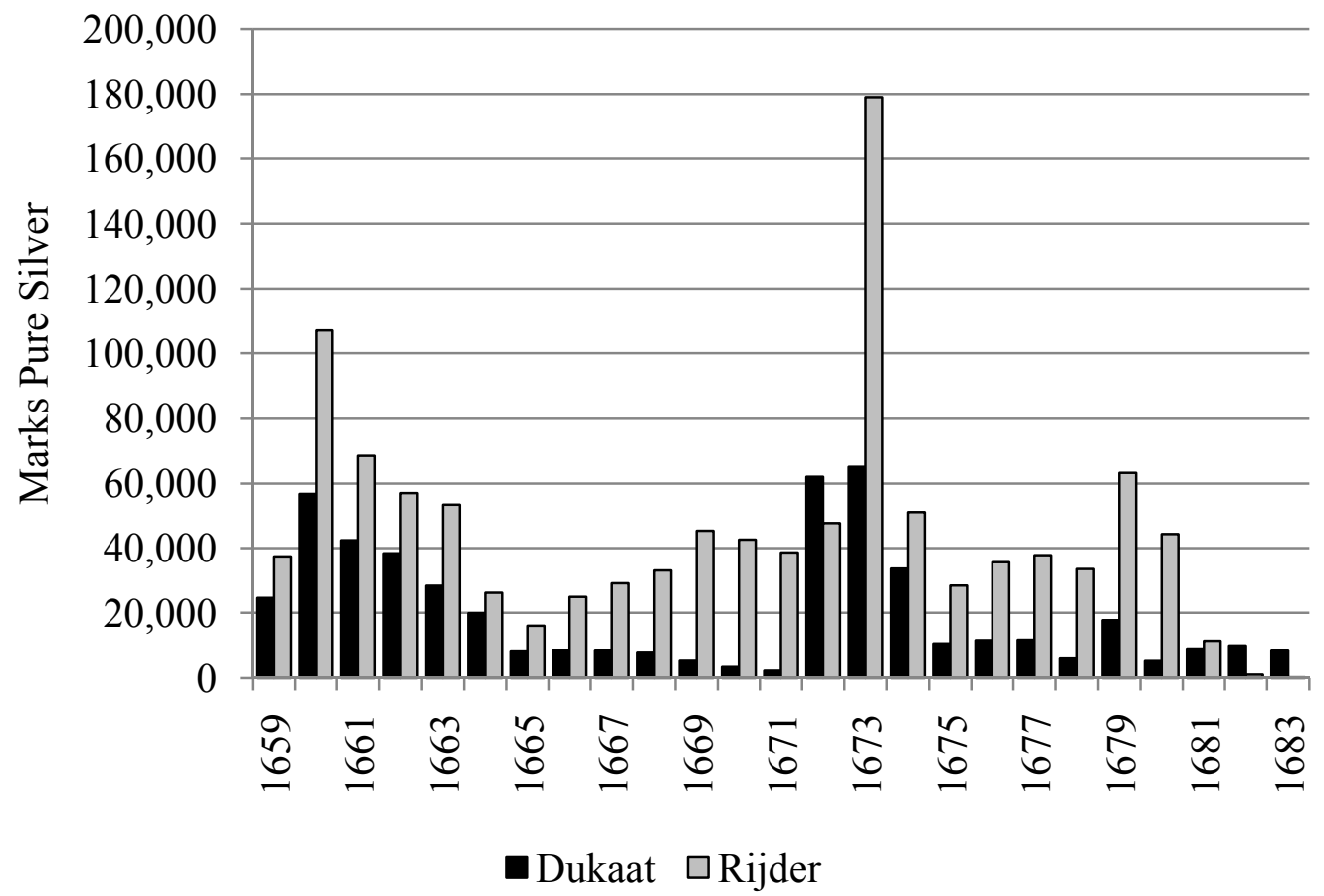

Source: Derived from Polak (1998, 103-164).

The paucity of dukaat coins limited the ability of AWB customers to favorably deposit $d u$ katen as the agio rose above 4.17 percent. At the same time, the new regime promoted deposits, so rijders dominated. To show this, figure 16 plots a measure of the types of coins deposited through use of yet another filtering algorithm: one built around sacks of coins. The 200 coin sack was the standard bulk unit, so a sack of dukaat coins was worth 480 bank guilders and a sack of rijders 600 bank guilders. We filtered the population of deposit transactions for amounts of exactly 480,600 , or their multiples up to times ten. Each observation is then converted into sacks, so, for example, 960 bank guilders converts into two sacks of dukaten. The sacks are then aggregated by month, and the joint-multiples of 2,400 and 4,800 are excluded. The result, Figure 16, shows that rijder deposits predominated when deposit amounts were low or high. Moreover, 
deposits did respond to arbitrage opportunities. When the agio flirted with 5 percent in 1670 and 1671, dukaten were attracted, but the much larger effect was the in-rush of rijders.

Figure 16. Filtered Sample of Deposits by Month by Coin

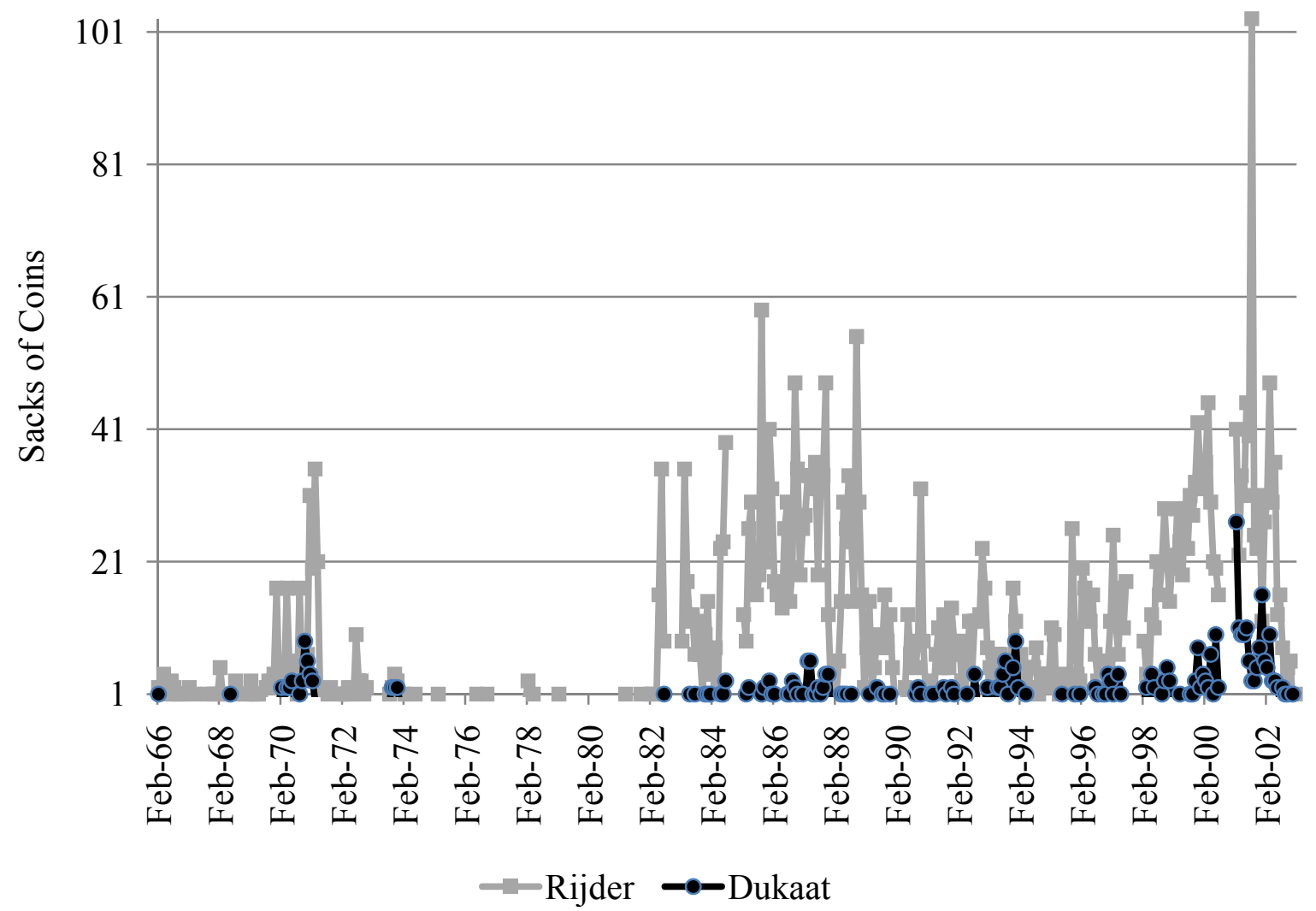

Source: Authors' calculation.

To summarize this sub-section, the tremendous drop in fees in 1683 created an arbitrageinduced corner solution. The rijder equilibrium won because the importance of agio-arbitrage was conditional on the minting environment. Few dukaat coins were in circulation at the time to meet the surge in demand for deposits, so the mean agio eventually moved towards the rijder's implicit agio of 5 percent. $^{50}$

\footnotetext{
${ }^{50}$ The scarcity of dukaten also helps explain the asymmetry in agio observations above the $d u$ kaat's upper agio boundary (4.17), for the rijder's range topped at 5 percent.
} 


\subsubsection{Agio dispersion}

If the rijder's no-arbitrage boundaries set the agio's trading range, then the reduction in fees in 1683 should have tightened the range (see Table 5), and the agio's variance should have also tightened. It did not until after 1693. Again, we think minting can help explain the high agios from 1685 to 1693.

From 1676 to 1693, some mints, especially Zeeland's provincial mint, began producing coins with higher mint prices than traditional dukaten or rijders. ${ }^{51}$ These "light" coins were an

effort to gain revenue. ${ }^{52}$ To get a sense of this, figure 17 plots the production of silver at the provincial mints in the form of traditional coins (dukaat, rijder, and gulden) and as the new, rival coins (arendsdaalder and florijn). ${ }^{53}$ The lighter (high mint equivalent) coins were displacing traditional coins until Holland refused to recognize their legal status in 1690, and the entire United Provinces banned their production in $1694 .^{54}$

\footnotetext{
${ }^{51}$ These new coins were large trade coins distinct from the small schellingen and stuivers referenced in footnote 26.

${ }_{53}^{52}$ A different version of the problem was the province of Overijssel debasing gulden coins in the late 1680s.

${ }^{53}$ Again, the caveats in footnote 48 apply.

${ }^{54}$ The data also suggest that sorting out the monetary uncertainty stimulated new minting.
} 
Figure 17. Annualized Trade Coin Production at Provincial Mints

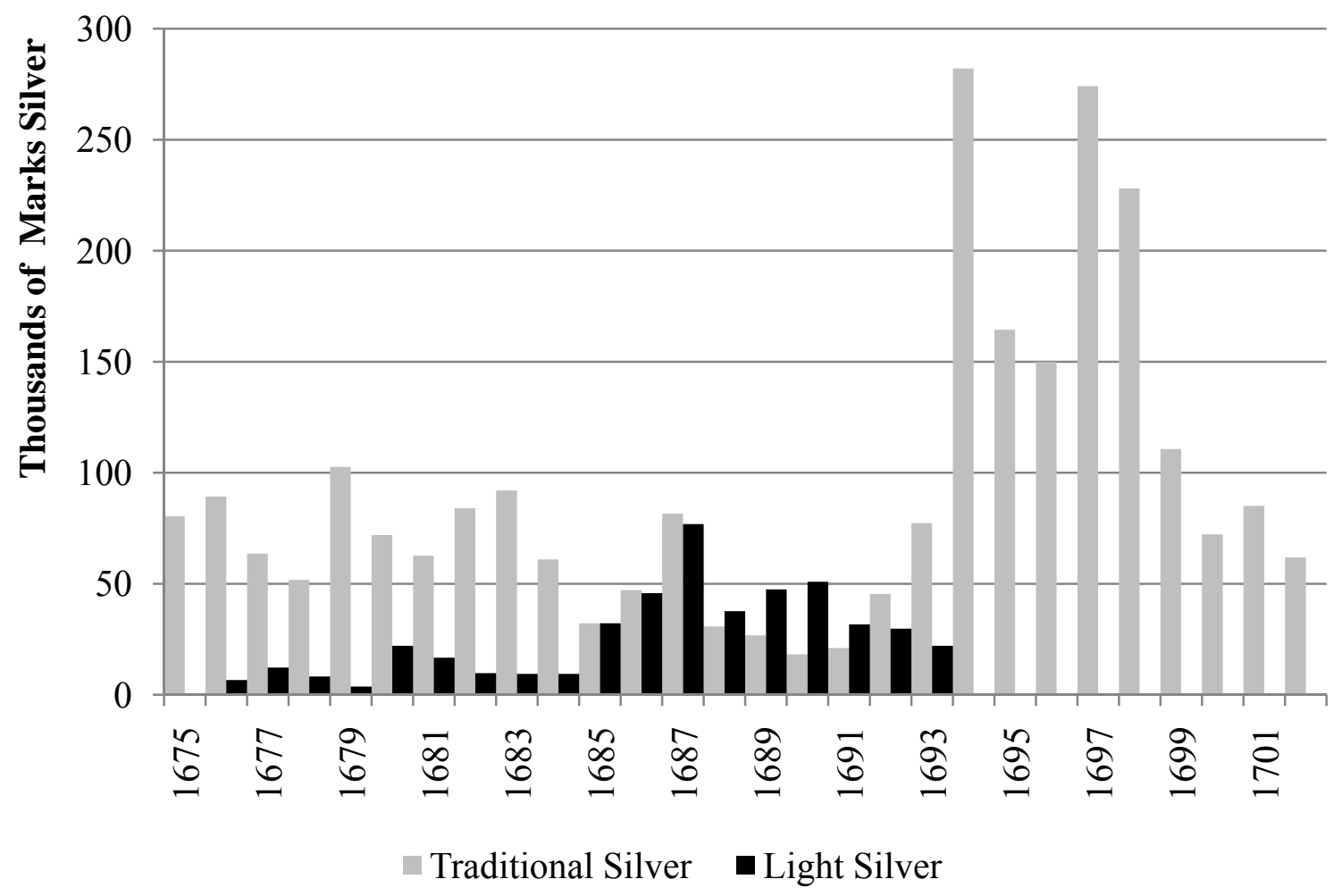

Source: Derived from Polak (1998, 103-164).

The new coins undermined the silver content of circulating current money, so the agio rose to historic highs. The AWB returned to its original role of sheltering creditors as agio-arbitrage and low fees encouraged deposits of rijders and dukaten (figure 16). The agio got so high that it paid to mint dukaat coins just to deposit them at the AWB. ${ }^{55}$ The agio peaked at 12.5 percent in January 1693 and hovered around 6.25 during the third quarter of 1693. Dukaat production at the provincial mints ${ }^{56}$ surged in 1693 and 1694, and we think the high agio drove the activity because rijder production did not surge. Again, rijders usually dominated production (figure 15). The dukaat's only advantage was an attractive agio when deposited at the AWB (table 5).

\footnotetext{
${ }^{55}$ This effect does not include the Zeeland dukaat. In 1672, Zeeland raised the ordinance value of its dukaat to 2.55 current guilders (Polak 1985, 73). With the end of arensdaalders in 1694, Zeeland switched to minting these "criedup" dukaten.

${ }^{56}$ As a caveat, we are unable to say if the rijder deposits from 1676 to 1690 include some arensdaalders.
} 
After 1693, observed agios stabilize between 5.25 and 4.38 for the rest of our sample period. ${ }^{57}$ The high agios in our post- 1683 sample reflect instability in the quality of current coins that gets sorted out in 1694. Otherwise, the agio distribution stays centered on the arbitrage boundaries set by the rijder coin.

\subsection{Open market operations}

The presence of arbitrage effects does not exclude the possibility that the bank sought to influence the agio through open market operations. Historical accounts (van Dillen, Mees, and others) agree that such operations occurred but are mute regarding their manner and extent. Our reconstruction of master account transactions points to the AWB buying and selling bullion rather than coin. Open market operations meant that the AWB would sell (buy) bullion below (above) the market price and decrease (increase) the quantity of bank guilders.

To what end? The AWB could attempt to stabilize the agio. Alternatively, the bank could mute the impact of fluctuations in bank money by offsetting deposits with bullion sales and withdrawals with bullion purchases, i.e., the bank could "sterilize" these flows in modern parlance (see, e.g., Hamilton 1997). The bank could similarly sterilize changes in VOC credit. This section presents evidence that the bank used bullion operations to pursue all three goals, and that the fiat money standard facilitated these operations by allowing more aggressive bullion sales.

\footnotetext{
${ }^{57}$ Our interpolated agios in Figure 3 are erratic around 1696 because the pound-bank guilder exchange reflected great monetary difficulties in England. England was experiencing a liquidity crisis as the Great Recoinage, begun in 1695, temporarily reduced the stock of circulating coins. For example, the Bank of England suspended convertibility in 1696 (Clapham 1944, 36).
} 


\subsubsection{Operations in bullion}

Why trade bullion rather than coin? ${ }^{58}$ Trading coin would have violated the bank's fundamental assignment of respecting and maintaining the mint ordinance values of coins. In contrast, bullion could be traded without necessarily upsetting the circulation of coins at all. To see this, suppose that a coin from the preceding section contains $b$ ounces of silver. Also, note that when mints offer to convert silver to coin, they collect a fraction $\sigma$ of the silver as seigniorage. If we take the market agio as $a$ and we normalize the coin's face value to unity, then the steady-state price of silver $\gamma$ (expressed as bank guilders per ounce) lies in the interval ${ }^{59}$

$$
(\underline{\gamma}, \bar{\gamma}) \equiv\left(\frac{1-\sigma}{b(1+a)}, \frac{1}{b(1+a)}\right) .
$$

The bank had to take these limits into account in its open market operations if it did not want to disrupt the circulation of coins.

The 1683 reform eased these constraints. Receipts allowed the AWB to purchase existing options to withdraw coins, so the stock of potentially circulating coins could be reduced without the bank offering an unofficial price. Lower fees also allowed the AWB to more easily "tighten" by selling bullion. To see the effect of lower fees on the range of bullion sale prices, insert the lower bound ( $\underline{a}$ ) for the agio in (1) into (2) to get bounds on the steady-state price of silver $\gamma$ when the agio is at its steady-state minimum:

$$
\left(\frac{1-\sigma}{b\left(\frac{1+\alpha}{1+w}\right)}, \frac{1}{b\left(\frac{1+\alpha}{1+w}\right)}\right)
$$

\footnotetext{
${ }^{58}$ Why not trade in government debt? Holland had no secondary market for sovereign debt in this era (Gelderblom and Jonker 2010).

${ }^{59}$ I.e., $\gamma$ lies in an interval formed by the mint price of the coin and the mint equivalent of the coin, converted to bank guilders at the market agio. See e.g., Redish (1990), Sargent and Smith (1997), or Sargent and Velde (2003) on the derivation of interval (2).
} 
The decrease in $w$ decreased the lower bound $\underline{\gamma}=(1-\sigma)(1+w) /[b(1+a)]$ in $(3)$, allowing the AWB to more easily sell bullion at a price above the mint's purchase price.

Receipts also eliminated the need for coin-specific premia by ending cross-coin substitution. To see why, assume two coins with (bank) nominal value/metal pairings of $\left(x_{1}, b_{1}\right)$ and $\left(x_{2}, b_{2}\right)$. Under traditional withdrawal rules, coin 1 needs a fee $w_{1} \geq \max \left(\frac{b_{1}}{b_{2}} \frac{x_{2}}{x_{1}}-1,0\right)$ to avoid coin-to-coin arbitrage. The receipt system avoided the problem by making all withdrawal claims a claim to a specific coin. All together, lower fees simultaneously tightened the agio $(\uparrow \underline{a})$ and eased the bank's ability to sell bullion $(\downarrow \underline{\gamma})$ when the agio was low: near $\underline{a}$. Also note that the effect is asymmetric, for reducing fees does not alter $\bar{a}$, (i.e., the upper bound in (1)) or $\bar{\gamma}$ (the upper bound in (3)) when the agio is high.

\subsubsection{Evidence of open market operations}

Returning to the data, the integrated series on purchases and deposits, graphed in Figure 8, provide a narrative to the bank's open market activity. Before 1683, open market activity seems to have had a defensive character. "Reserves" of metal were accumulated by large purchases at favorable times. Purchased metal was rarely drawn down through sales, the chief exception being the years $1680-83$, by which point virtually no coin was being deposited (see Figure 5) and cumulated deposits were approximately zero (Figure 8). After 1683, infrequent spikes in purchases continue as before, but these are followed by lengthy periods over which the bank is a net seller of metal (1685-87, 1691-94, 1695-98, 1699 onward). By then the bank apparently felt more comfortable parting with its metal purchases than it did before the 1683 reform.

Months with the largest purchases and sales are cataloged in Table 6 below. 


\section{Table 6. Potential Large Open Market Operations}

5a. Bullion Purchases/ Sales of Bank Money

$\begin{array}{crccc}\text { Month } & \text { Size (guilders) } & \begin{array}{c}\text { Size } \\ \text { (\% total balances) }\end{array} & \text { Agio } & \begin{array}{c}\text { Compared to } \\ \text { Agios } \\ +/-12 \text { months }\end{array} \\ \text { May-68 } & 1,437,506.25 & 24 \% & 4.00 & \begin{array}{c}\text { Highest } \\ \text { Aug-70 }\end{array} \\ \text { Sep-70 } & 1,415,231.20 & 12 \% & 4.72 & \text { High } \\ \text { Dec-79 } & 994,726.48 & 18 \% & 4.90 & \text { High } \\ \text { Feb-80 } & 807,539.45 & 17 \% & 4.47 & \text { Highest } \\ \text { Oct-85 } & 1,909,653.70 & 10 \% & 4.44 & \text { High } \\ \text { May-94 } & 1,022,275.45 & 29 \% & 5.13 & \text { High } \\ \text { Oct-98 } & 706,765.30 & 5 \% & 4.69 & \text { Low } \\ \text { Nov-98 } & 899,359.70 & 6 \% & 5.00 & \text { High } \\ & & & 5.19 & \text { High }\end{array}$

5b. Bullion Sales/ Purchases of Bank Money

$\begin{array}{ccccc}\text { Month } & \text { Size (guilders) } & \begin{array}{c}\text { Size } \\ \text { (\% total balances) }\end{array} & \text { Agio } & \begin{array}{c}\text { Compared to } \\ \text { Agios } \\ +/-12 \text { months }\end{array} \\ \text { Nov-67 } & 340,681.90 & 5 \% & 3.19 & \text { Lowest } \\ \text { Sep-70 } & 573,082.22 & 7 \% & 4.90 & \text { High } \\ \text { Nov-75 } & 308,633.05 & 6 \% & 3.53 & \text { Low } \\ \text { Nov-77 } & 409,548.10 & 7 \% & 3.75 & \text { Low } \\ \text { Nov-81 } & 501,789.50 & 7 \% & 3.63 & \text { Low } \\ \text { Dec-86 } & 612,842.55 & 6 \% & 5.25 & \text { High } \\ \text { May-91 } & 450,312.75 & 4 \% & 5.25 & \text { Low } \\ \text { Nov-94 } & 300,312.27 & 2 \% & 4.75 & \text { Low }\end{array}$

Notes: Operations are classified as "large" if they are more than 3 standard deviations above the series mean. Agios with italic font are same month; normal font is closest month available. 
A case-by-case examination indicates that these exceptional transactions almost always leaned against the wind: metal was purchased during periods of high agios, and vice versa. ${ }^{60}$ In addition, the AWB's large purchases are often approximately offset by large deposit outflows, and vice-versa for large sales. Net purchases and net deposits almost exactly line up on a negatively sloped $45^{\circ}$ line for many high-value observations, both before and after 1683 (figure 18), consistent with the hypothesis that these were essentially sterilization operations.

\section{Figure 18: Net Purchases versus Net Deposits (Bank Guilders)}
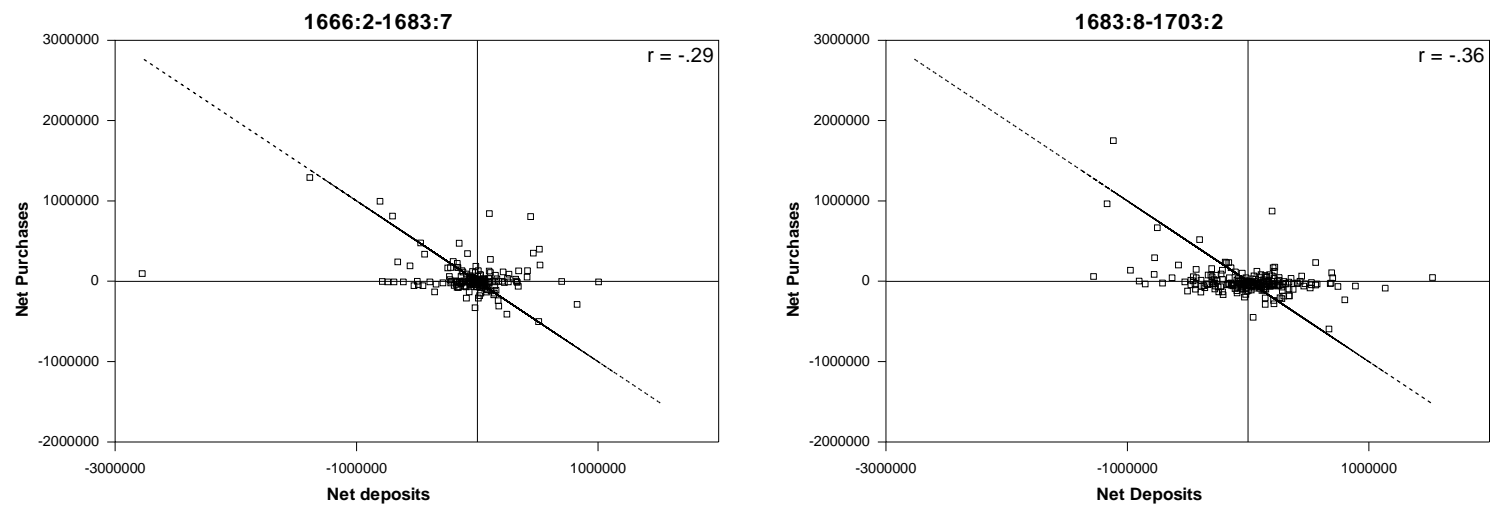

Source: Appendix A.

Offsetting of purchases and balances is confirmed in a more formal exercise in which a standard vector autoregression was fit to the four principal data series (the agio, VOC debt, cumulated deposits, and cumulated purchases). The VAR was fit over a sample that includes all available observations on balances, except the two outlier episodes in 1672 and 1693 . The specification includes monthly dummies and 2 lags. ${ }^{61}$ Stationarity of the model coefficients across the

\footnotetext{
${ }^{60}$ Exceptions are the large bullion purchase in May 1994 and sales in September 1670 and December 1686; however, these transactions represent partial unwindings of transactions in the opposite direction during the same or previous month.

${ }^{61}$ The 2-lag specification is chosen under the Akaike, Hannan-Quinn, and Schwarz criteria; sequential likelihood ratio tests choose more lags.
} 
1683 break is strongly rejected by a classical likelihood ratio test $(p<.001) .{ }^{62} 36$-month impulse responses from the two VARs (pre- and post-1683) are graphed in figure 19. Responses shown are for a Choleski decomposition of the forecast error variance-covariance matrix with the agio first in the ordering. ${ }^{63}$

\section{Figure 19. Sample impulse responses}

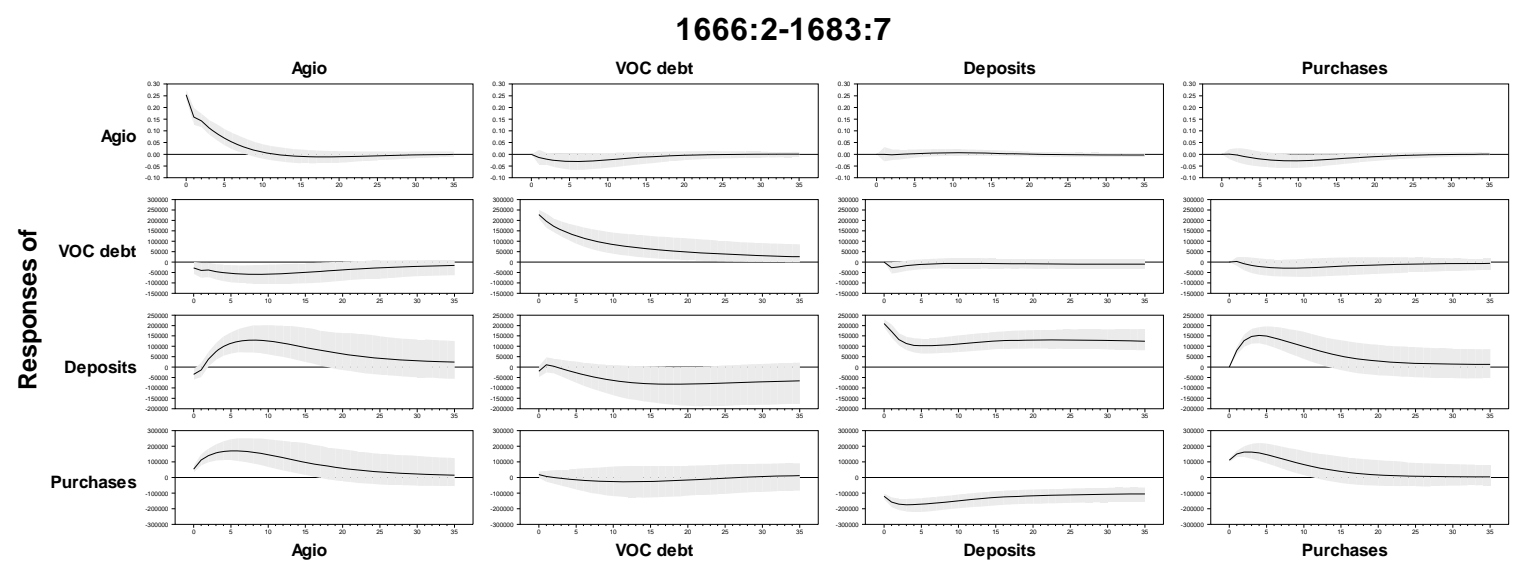

1683:8-1703:2
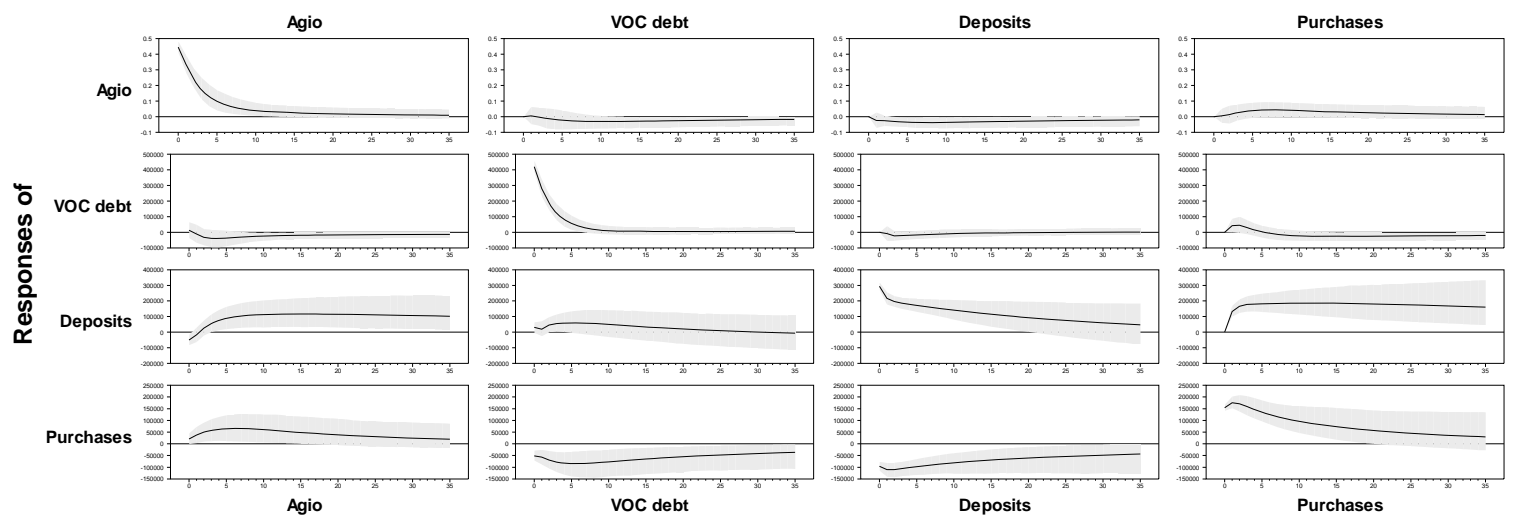

Noteworthy in figure 19 are the persistently negative responses of purchases to shocks to deposits, both before and after 1683, consistent with the idea that the bank's open market opera-

\footnotetext{
${ }^{62}$ Stationarity of coefficients is also rejected under the Akaike and Hannan-Quinn criteria; however stationary is favored under the Schwarz criterion.

${ }^{63}$ The graphs depict posterior mean responses under a diffuse prior, together with ninety percent posterior error bands.
} 
tions worked to smooth short-term fluctuations in the money stock. Shocks to deposits are less persistent after 1683 , perhaps reflecting greater efficacy of the bank's operations after the transition. Post-1683 shocks to VOC balances also induce sales of metal by the bank, suggesting that these fluctuations were partly sterilized. Also of interest are the responses of purchases to shocks to the agio. These are persistently positive, implying that the bank added funds to the market when bank balances became unexpectedly scarce, and drained funds when money was plentiful.

Summarizing this section, our analysis suggests that the bank conducted open market operations throughout the sample period, with some purchase operations in particular being quite aggressive. There is a strong negative correlation between shocks to deposits and shocks to purchases, indicating that the motivation for many of these operations was to smooth fluctuations in the money stock rather than to stabilize the agio. The 1683 regime change both encouraged deposit flows and eased arbitrage constraints on the bank, allowing the AWB greater latitude to sell off purchased metal.

\section{Connections to the literature}

The above analysis invites comparison to similar analyses of U.S. macro time series before and after the 1913 founding of the Federal Reserve. Numerous studies (e.g., Clark 1986, Miron 1986, Mankiw, Miron, and Weil 1987) have documented that U.S. interest rates become extremely persistent and virtually aseasonal starting in 1914, while monetary aggregates display increased seasonality. These changes are often attributed to Federal Reserve policies, especially a quasi-pegging of short-term interest rates through the opening of the discount window.

Figures 5 and 6 show that comparable shifts do not occur around 1683, except in the increased seasonality of VOC loan balances. Constancy in seasonal patterns for the other two 
components of the money stock is consistent with the more evolutionary nature of the 1683 policy change, and the AWB's restriction of seasonal lending to a single counterparty.

The VAR analysis reported in Canova (1991, 700-701) (see also Tallman and Moen 1998) finds that before 1914, external shocks to high-powered money are highly causal for the U.S. domestic money stock, but that this same effect is greatly diluted after 1914. We cannot fully replicate Canova's exercise due to data limitations (monthly observations on key macro series such as output and prices are unavailable), but figure 15 displays some similarity to the pre-1914 U.S. case: favorable shocks to the agio (to the extent these originate abroad) have a persistent positive impact on money. In contrast to the post-1914 U.S. experience, however, this pattern attenuates somewhat but does not disappear after 1683 .

Some aspects of the AWB's operations resemble those of modern currency boards. E.g., the Hong Kong Monetary Authority has standing offers to sell Hong Kong dollars at a unit price of US $\$ 0.129$ and to repurchase its money at a $1.27 \%$ lower price, roughly matching the AWB's pre-1683 statutory bid-ask spread. The receipt system evidently allowed the bank to function with a lower "backing ratio" of external assets to central bank money than do modern currency boards, which often operate with a backing ratio of 100 percent or more.

Currency boards can be effective in stabilizing monetary value, but a commonly cited defect is their inability to ward off banking crises (Chang and Velasco 1999, 2000). Yet no widespread banking crises occurred in Amsterdam during the period we analyze. This is perhaps due to Amsterdam's reliance on a web of informal trade credit and personal guarantees (bills of exchange) for business financing, rather than deposit banks. And, as has been demonstrated, the AWB could and did indirectly ease credit conditions by providing financing to the largest enterprise in the economy. 
In the eighteenth century, Amsterdam expanded its credit markets at the cost of increased financial fragility. A system of "acceptance credit" developed, under which bills of exchange were guaranteed against default ("accepted") by one of a small number of prominent local merchants, lowering the chances of a single default but concentrating credit risk in a small number of counterparties. A full-fledged financial panic developed in 1763 after the failure of a prominent acceptance house; the AWB could do little in response (Schnabel and Shin 2004).

\section{Epilogue and conclusion}

The innovations of 1683 - the move to a de facto fiat standard — made it possible for the Bank of Amsterdam to conduct credit and monetary policy on terms comparable to modern central banks. Our analysis shows that this change allowed the bank to lend with little if any capital, and to counter money outflows through sales of its metal stock. The weakness of this system lay in its dynamics: having no natural endowment of precious metal, Amsterdam's liquidity required access to external supply of silver. Following the outbreak of the Fourth Anglo-Dutch War in 1780, silver inflows were curtailed and the bank's loans to the East India Company sharply expanded, even as chances of their repayment diminished. Erosion of confidence led to a sharp depreciation of the bank guilder, and by 1795 the world's first great experiment with fiat money largely had come to an end (van Dillen 1934, 112-115).

Does the Amsterdam experience offer any insights for monetary policy today? Our answer is yes, precisely for the reason that, as first movers, the masterminds of the 1683 reform could construct a fiat money scheme unburdened by any modern ideas about central banking. The resulting system, conceived in this "state of nature," emphasized straightforward policies adapted from earlier experience under a commodity standard. In monetary terms, the bank acted to in- 
crease the market value of its liabilities, i.e., the agio, in terms of externally valued collateral. In credit terms, the bank lent in restrained amounts, though on generous terms, to a blue-chip (and government-sponsored) borrower. Profits from these activities were quietly returned to the bank's sponsor, the City of Amsterdam.

Simplicity was the hallmark of the bank's operations. There was little need for policy statements, elaborate targeting schemes, or exit strategies. Paradoxically, secrecy also played a role: while the general intent of the bank's operations was public information, its financial condition was not. Many contemporary observers, Adam Smith included, believed the AWB to possess a stock of metal far in excess of its actual holdings, and the bank's true condition was revealed only after its final collapse. Until that point, the managers of the world's first big fiat money factory seem to have absorbed a lesson familiar to today's high-tech mavens: for a virtual good, reputation is everything. 


\section{References}

Bartolini, Leonardo, Spence Hilton, and James McAndrews, (2008). "Settlement Delays in the Money Market.” Staff Report 319, Federal Reserve Bank of New York.

Canova, Fabio. 1991. "The Sources of Financial Crisis: Pre- and Post-Fed Evidence.” International Economic Review 32(3), 689-713.

Chang, Roberto and Andrès Velasco. 1999. "Liquidity Crises in Emerging Markets: Theory and Policy." NBER Macroeconomics Annual 14, 11-58.

Chang, Roberto and Andrès Velasco. 2000. "Financial Fragility and the Exchange Rate Regime." Journal of Economic Theory 92, 1-34.

Clapham, John. 1944. The Bank of England, a History: Volume I. Cambridge University Press, Cambridge.

Clark, Truman A. 1986. "Interest Rate Seasonals and the Federal Reserve." Journal of Political Economy 94(1), 76-125.

Dehing, Pit, and Marjolein 't Hart. 1997. "Linking the fortunes, currency and banking, 15501800." In A Financial History of the Netherlands, ed. Marjolein 't Hart, Joost Jonker and Jan Luiten van Zanden, 37-63. Cambridge University Press, Cambridge.

De Vries, Jan, and Ad van der Woude. 1997. The First Modern Economy, Success, Failure and Perseverance of the Dutch Economy, 1500-1815. Cambridge University Press, Cambridge.

Furfine, Craig H., 1999. "The Microstructure of the Federal Funds Market.” Financial Markets, Instruments, and Institutions 8(5), 24-44.

Furfine, Craig H., 2001. "Banks as Monitors of Other Banks: Evidence from the Overnight Federal Funds market," Journal of Business 74(1), 33-57.

Furfine, Craig H., 2003. "Interbank Exposures: Quantifying the Risk of Contagion," Journal of Money, Credit, and Banking 35(1), 111-128.

Furfine, Craig H. 2006. "The Costs and Benefits of Moral Suasion: Evidence from the Rescue of Long-Term Capital Management,” Journal of Business 79(2), 593-622.

Gelderblom, Oscar and Joost Jonker, 2010. "A Conditional Miracle. The Market Forces that Shaped Holland's Public Debt Management, 1514-1713.” Working Paper, Utrecht University. 
Gillard, Lucien. 2004. La banque d'Amsterdam et le florin européen au temps de la République neerlandaise, 1610-1820. L'École des hautes études en sciences sociales, Paris.

Goodfriend, Marvin and Robert G. King. 1988. "Financial Regulation, Monetary Policy, and Central Banking." Federal Reserve Bank of Richmond Economic Review (May/June), 322.

Hamilton, James D. 1997. "Measuring the Liquidity Effect.” American Economic Review 87(1), 80-97.

Mankiw, N. Gregory, Jeffrey A. Miron, and David N. Weil. 1987. "The Adjustment of Expectations to a Change in Regime: A Study of the Founding of the Federal Reserve." American Economic Review 77(3), 358-374.

McAndrews, James J. and Potter, Simon M., 2002. "Liquidity effects of the events of September 11, 2001." Federal Reserve Bank of New York Economic Policy Review 8(2), 59-79.

McAndrews, James J. and Samira Rajan, 2000. "The Timing and Funding of Fedwire Funds Transfers." Federal Reserve Bank of New York Economic Policy Review 6(2), 17-32.

McCusker, John. 1978. Money and Exchange in Europe and America, 1600-1775. University of North Carolina Press, Chapel Hill.

Mees, Willem C. 1838. Proeve eener Geschiedenis van het Bankwezen in Nederland geduerende den Tijd der Republiek. W. Messcuert, Rotterdam.

Miron, Jeffrey A. 1986. "Financial Panics, the Seasonality of the Nominal Interest Rate, and the Founding of the Fed." American Economic Review 76(1), 125-140.

Neal, Larry. 2000. "How It All Began: The Monetary and Financial Architecture of Europe During the First Global Capital Markets, 1648-1815." Financial History Review, 7: 117-140.

Polak, Menno. 1998. Historiografie en Economie van de "Muntchaos," Deel II. NEHA, Amsterdam.

Quinn, Stephen and William Roberds. 2007. "The Bank of Amsterdam and the Leap to Central Bank Money." American Economic Review Papers and Proceedings 97: 262-5.

Quinn, Stephen and William Roberds. 2009a. "An Economic Explanation of the Early Bank of Amsterdam, Debasement, Bills of Exchange and the Emergence of the First Central Bank." In The Evolution of Financial Institutions from the Seventeenth to the TwentiethFirst Century (2009), ed. Jeremy Atack and Larry Neal, 32-70. Cambridge University Press. 
Quinn, Stephen and William Roberds. 2009b. "Coinage, central bank money and the Bank of Amsterdam." In The Bank of Amsterdam: on the Origins of Central Banking, ed. Marius van Nieuwkerk: 92-107. Sonsbeek Publishers, Amsterdam.

Redish, A. 1990, Evolution of the gold standard in England, Journal of Economic History 30, 789-805.

Sargent, Thomas J. and Bruce D. Smith. 1997. "Coinage, debasement, and Gresham's Laws," Economic Theory 10: 197-226.

Sargent, T. J. and F. R. Velde. 2003. The Big Problem of Small Change. Princeton University Press, Princeton.

Sargent, T. J. and N. Wallace, 1983. "A model of commodity money," Journal of Monetary Economics 12, 163-187.

Schnabel, Isabel and Hyun Song Shin. 2004. "Liquidity and Contagion: The Crisis of 1763." Journal of the European Economic Association 2(6): 929-968.

Steuart, James. 1805. The Works, Political, Metaphysical and Chronological, of the late Sir James Steuart of Coltness, Bart., now first collected, with Anecdotes of the Author, by his Son, General Sir James Denham Steuart. Volume III: of Money and Coin. Cadell and Davies, London.

Tallman, Ellis and Jon Moen. 1998. "Gold Shocks, Liquidity and the United States Economy during the National Banking Era." Explorations in Economic History 35: 381-404.

't Hart, Marjolein, 2009. “Corporate Governance.” In The Bank of Amsterdam: on the Origins of Central Banking, ed. Marius van Nieuwkerk: 144-155. Sonsbeek Publishers, Amsterdam.

Uittenbogaard, Roland. 2009. "Lending by the Bank of Amsterdam (1609-1802)." In The Bank of Amsterdam: on the Origins of Central Banking, ed. Marius van Nieuwkerk: 120-131. Sonsbeek Publishers, Amsterdam.

Van Dillen, Johannes Gerard. 1921. "Een Boek van Phoonsen over de Amsterdamsche Wisselbank." Economisch-historish jaarboek 7, 1-146.

Van Dillen, Johannes Gerard. 1925. Bronnen Tot de Geschiedenis Der Wisselbanken. Martinus Nijhoff, The Hague.

Van Dillen, Johannes Gerard. 1934. "The Bank of Amsterdam.” In History of the Principal Public Banks, ed. Johannes Gerard van Dillen, 79-124. Martinus Nijhoff, The Hague.

Van Dillen Johannes Gerard. 1964a. "Oprichting en Functie der Amsterdamse Wisselbank in de zeventiende Eeuw 1609-1686," in J.G. van Dillen, ed. Mensen en Achtergronden, Studies 
uitgegeven ter gelegenheid van de tachtigste jaardag van de schrijver. J.B. Wolters, Groningen.

Van Dillen Johannes Gerard. 1964b. "Bloeitijd der Amsterdamse Wisselbank 1687-1781," in J.G. van Dillen, ed. Mensen en Achtergronden, Studies uitgegeven ter gelegenheid van de tachtigste jaardag van de schrijver. J.B. Wolters, Groningen.

Van Nieuwkerk, Marius (ed.), 2009. The Bank of Amsterdam: on the Origins of Central Banking. Sonsbeek Publishers, Amsterdam.

Van Zanden, Jan Luiten, 2004. "The prices of the most important consumer goods, and indices of wages and the cost of living in the western part of the Netherlands, 1450-1800." Accessed online at www.iisg.nl/hpw/data.php\#netherlands.

Willemsen, René. 2009. "The Activities of the Bank of Amsterdam." In The Bank of Amsterdam: on the Origins of Central Banking, ed. Marius van Nieuwkerk: 78-91. Sonsbeek Publishers, Amsterdam. 
Supplementary material for

\section{How Amsterdam got Fiat Money}

Stephen Quinn, Texas Christian University

William Roberds, Federal Reserve Bank of Atlanta 


\section{Appendix A: AWB Accounting}

\section{The Balance Sheet}

The AWB fiscal year ended in January, so the bank's balance sheet sums categories on January 31. In bank guilders, the AWB reported its assets as metal held and loans due, its liabilities were account balances, and the residual was capital. See Table 1 in the text for an example. Van Dillen (1925: 701-807) reproduces these from AWB records, and we have consolidated them for our sample period in Table A1.

Because the balance sheet is a double entry system, changes in year-to-year balances have an offsetting change in another category. Bank operations that alter the balance sheet can be organized within a matrix intersecting balances, metal, loans and capital. Figure A1 shows the possibilities and assigns different AWB operations to the appropriate categories. Traditional deposits and withdrawals are only the start.

Figure A1. Cross-Category AWB Operations

\begin{tabular}{|c|c|c|c|}
\hline & Metal & Loans & Capital \\
\hline Balances & $\begin{array}{l}\text { Deposits } \\
\text { Withdrawals } \\
\text { Bullion purchases and sales }\end{array}$ & $\begin{array}{l}\text { "Account" Lending: } \\
\text { All VOC, Some Amsterdam }\end{array}$ & $\begin{array}{l}\text { VOC Interest } \\
\text { Some Expenses }\end{array}$ \\
\hline Capital & $\begin{array}{l}\text { Fee Revenue } \\
\text { Holland Interest } \\
\text { Most Expenses } \\
\text { Special Deposits } \\
\text { Open Market Profit/Loss }\end{array}$ & $\begin{array}{l}\text { Interest Due } \\
\text { Loan Write-Offs }\end{array}$ & \\
\hline Loans & $\begin{array}{l}\text { "Metal" Lending: } \\
\text { All Holland, All Miscellaneous, } \\
\text { Some Amsterdam }\end{array}$ & & \\
\hline
\end{tabular}

\section{Loans}

Loans were granted by creating account balances (VOC) or by releasing metal (Holland). Amsterdam used both techniques. Principal repayment reversed the process.

\section{Capital Accumulation}

Capital grew through the bank's retained earnings. Interest payments by account eliminated bank guilders while interest payments by metal increased the bank's metal stock. If the bank 
considered interest due on January 31, then the AWB added the interest due to the loan's principal and to the bank's capital at that time. Other revenue from fees on withdrawals, account overdrafts, receipts and money changing were collected in coin, so the metal stock increased from those operations.

\section{Capital Extraction}

Removing capital was the prerogative of the City of Amsterdam. When the city decided to extract retained earnings, it did so by "borrowing" from the AWB at no interest instead of reducing capital. It appears the city did this to avoid explicitly putting the AWB into a negative capital. This situation seems to have evolved. In the early 1650s, the city borrowed around 2 million guilders from the AWB to help build a new city hall (and home for the bank) on the Dam. Soon, the city stopped paying interest, for why pay your own bank? Beginning in 1685, when retained earnings had built sufficient capital, the city had the AWB write off both capital and some of the bank's outstanding loans to the city until the AWB's book capital was again near zero, but not negative.

We agree with Willemsen (2009) that the city's taking of metal and creating of balances should be treated as capital extraction rather than as loans. To see the consequences of this interpretation, we calculate adjusted values for capital, loans, and assets. Adjusted capital subtracts the money from capital when the operation occurred instead of when the AWB later wrote-off the loan. Adjusted loans do not add the city as a borrower and do not subsequently write down those loans. Adjusted assets use the adjusted loans series: metal stock plus adjusted loans. Adjustment also ignores VOC interest due, but that is a minor issue.

To create a monthly series, known changes in balances, loans, capital and metal have been applied to year start values. This information came from Van Dillen (1925: 701-807), extant balance books (Amsterdam Municipal Archive 5077/1311 through 1323), and our reconstruction of the flow of balances described in Section II below.

We do not know the intra-year dispersion of non-interest profit, so we distributed the annual change per month by withdrawal weight. The logic being that withdrawal fees were the largest non-interest source of revenue. For years we lack complete withdrawal information, the annual non-interest profit was evenly distributed per month. Discrepancies in balances and metal 
are ignored within a year, and all levels are updated to reported levels (van Dillen 1925) at year start. We did not calculate book capital by month, so that series is only reported at year start.

Figure A2 compares book and adjusted capital-to-asset ratios. Figure A3 compares book and adjusted loans-to-asset ratios.

Figure A2. AWB Monthly Capital-to-Asset Ratios, 1666 to 1703

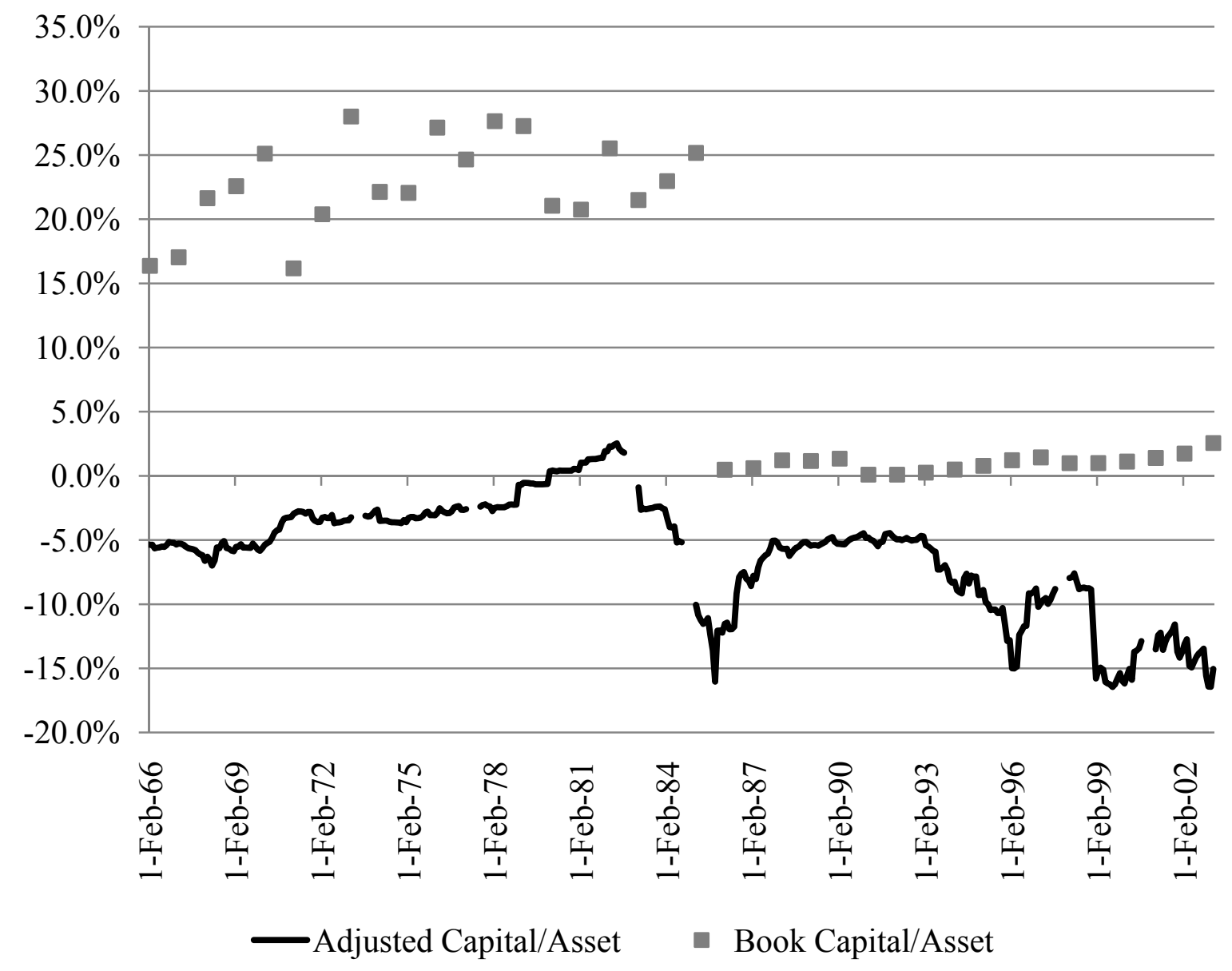

Source: Derived by authors from van Dillen (1925, 701-807). 
Figure A3. AWB Monthly Loan-to-Asset Ratios, 1666 to 1703

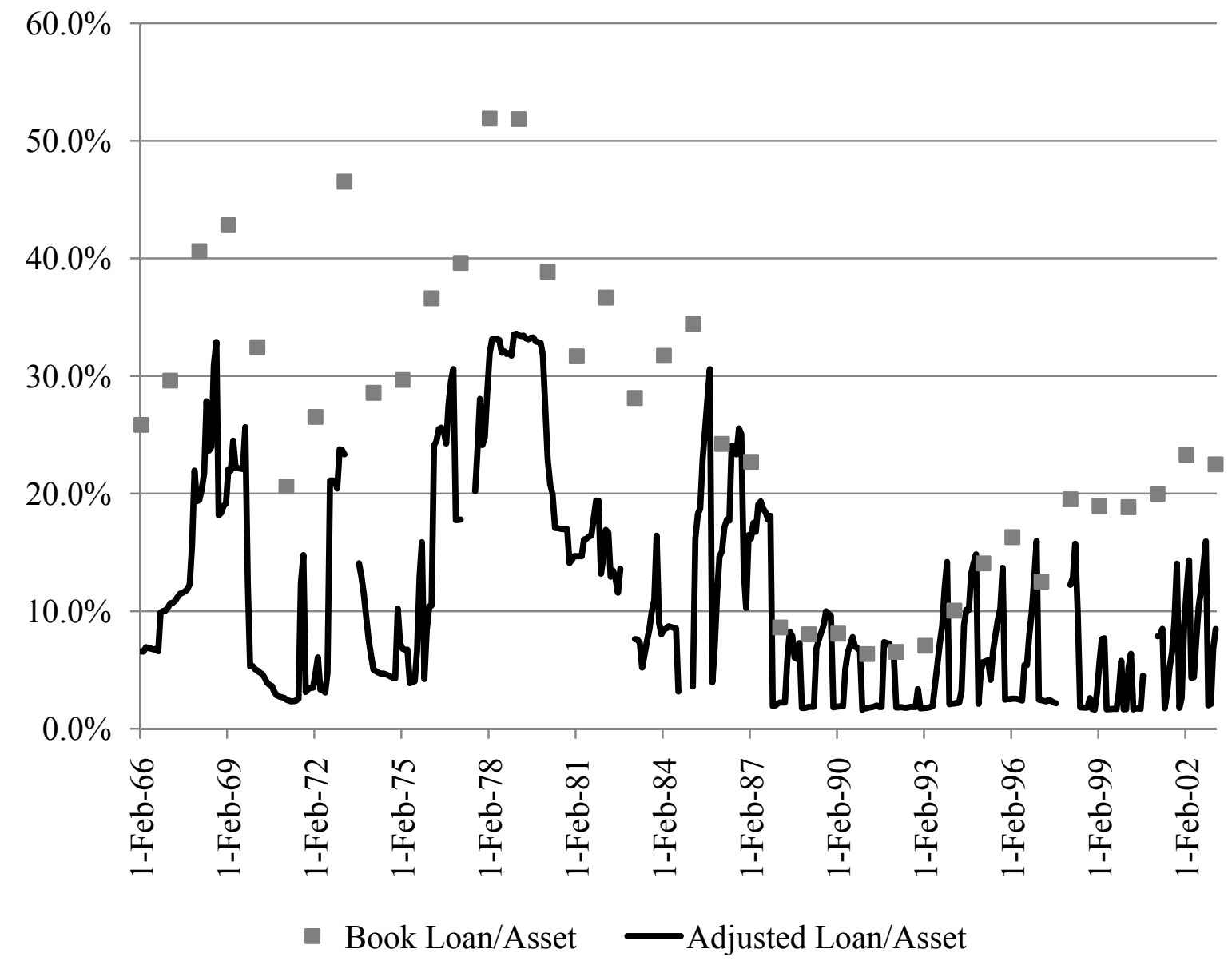

Source: Derived by authors from van Dillen (1925, 701-807).

The AWB balance sheet, however, does not communicate two important categories of information: gross flows and intra-category activity. The next sections report our efforts to reconstruct gross flows between bank accounts and the other balance sheet categories (see Figure A1).

\section{The Specie Kamer}

To account for the creation and destruction of bank guilders, the AWB used a master account called the Specie Kamer (or Kammer or Camer) that translates as specie room. Specie Kamer transactions are the top row of Figure A1: deposits and withdrawals (account-metal), VOC and some Amsterdam loans (account-loan), VOC interest payments and some AWB ex- 
pense payments (account-capital). The bulk of this paper's evidential contribution has involved using the Specie Kamer to reconstruct these transactions. This section details how we did this and what we found.

The Bank of Amsterdam organized its books by half-year increments: February through July, August through January. By the 1700s, the bank needed 3,000 pages to record each halfyear of bank activity. The amount of information in the ledgers is staggering. Fortunately for our purposes, the Specie Kamer master accounts are only a few pages per ledger.

\section{Receivers}

The bank used two sets of accounts to represent itself. When customers brought a deposit to the bank, the bank usually debited an account in the name of the employee who received the metal. Most years, the bank had two or three such receivers, and this system began in the 1620 s. When metal left, the Bank of Amsterdam credited the Specie Kamer. As a result, the combination of receiver debits and the specie room credits gives the changes in the amount of bank money. Figure A4 offers a schematic of the flow of metal and bank money through the bank. Table A3 lists the 74 ledgers and 812 folios used in this study. All ledgers are stored at the Amsterdam Municipal Archives, and the archive retains dissemination rights over the images. The folios were digitally photographed and then encoded. 
Figure A4. Standard Metal Flow through the Bank of Amsterdam

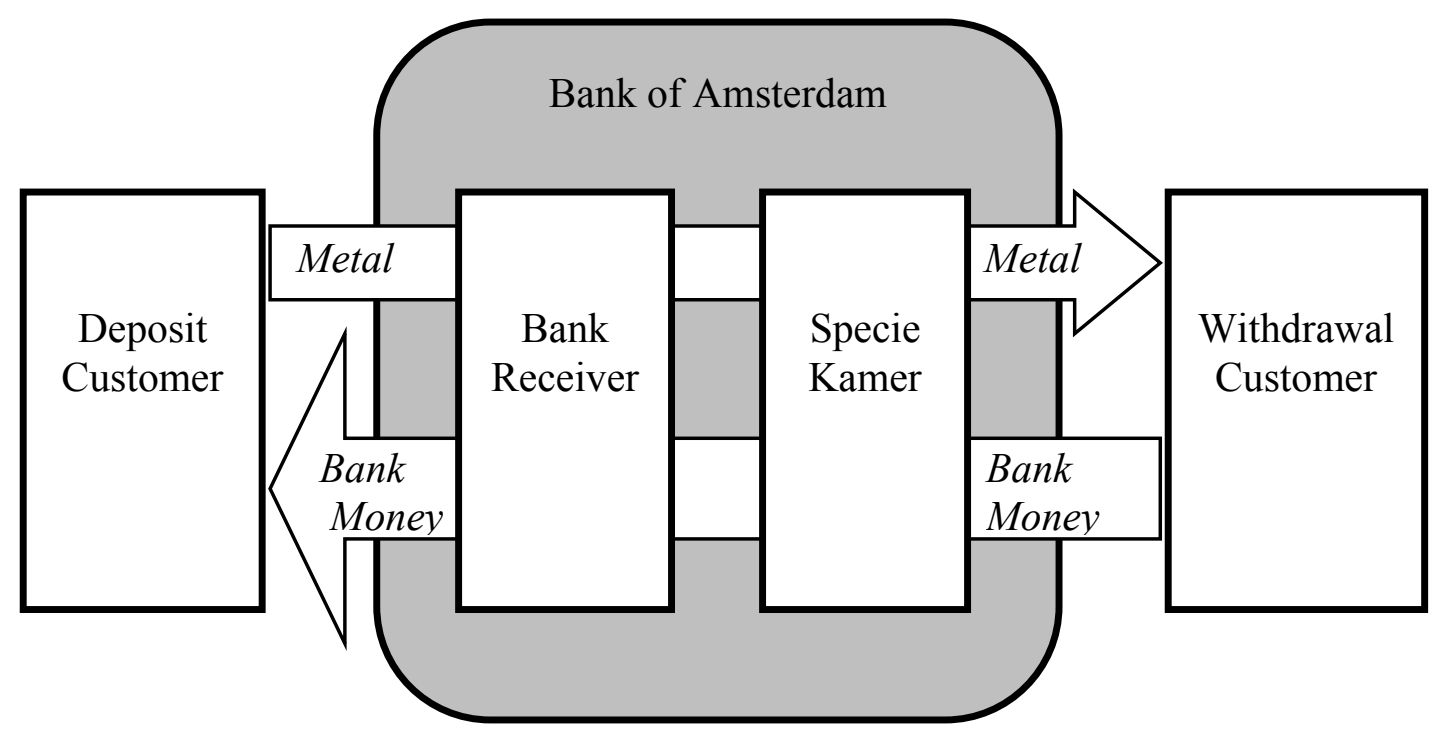

Here is an example of how the deposit process worked. On 23 May 1687, Arthur Woodward received metal worth 480 bank guilders from Samuel Cohen (5077/109, f.1407). Cohen's account was credited and Woodward's account was debited. The ledger does not report what Cohen deposited, but it was likely a sack (a standard unit for bulk coins) of 200 silver Dukaat coins at 2.4 guilders each. If so, then Cohen also should have received a receipt granting the option to buy 200 Dukaten from the AWB for 480 bank guilders. We say should because the account ledgers never mention receipts. Two weeks later, on June 6, Woodward transferred 46,800 guilders in metal to the Specie Kamer: Woodward's account was credited (5077/109, f. 1445) and the Specie Kamer debited (5077/109, f. 1431).

\section{Non-Metallic Guilder Creation}

Some guilder creation, however, did not involve incoming metal, and the AWB recorded these directly in the Specie Kamer account and bypassing the receivers. For example, when the VOC borrowed money from the AWB, the VOC's account was credited and the Specie Kamer was debited. To create our borrowing and repayment series, we separate account loans from deposits and repayments from withdrawals.

For some years, extant AWB records tell exact loan creation, repayment and interest payments (AMA 5077/1311 through 1323), so we found the matching transactions. For other years, 
van Dillen $(1925,979-84)$ provides total VOC borrowing, repayment and interest, so the matching transactions can be readily found, for the transactions were labeled VOC, and borrowing occurred in 100,000 guilder increments, with the rare exception of a 50,000 increment. Repayments are similarly named and carry the correct amounts for interest.

For the remaining years (1671 through 1675 and 1683 through 1684), the challenge is accounting for loans when we have only year start and year end debt levels. For these years, we have looked for 1) large, round VOC debits and 2) offsetting VOC credits that include the correct interest that 3) combine to leave the correct debt outstanding. Table A4 reports the loans we have identified. The interest rate was a consistent 4 percent except for anticipations in the mid1670s (de Korte 1984, 66), and the internal rates of return reflect that rate. Finally, we note that the ledger for August 1684 to January 1685 is missing and detailed summaries are missing, so we know nothing about that period except that 400,000 guilders in principal was retired.

Occasionally, the City of Amsterdam also created accounts without depositing metal. As with the VOC, the AWB credited the City of Amsterdam by debiting the Specie Kamer. These transactions are detailed in the bank's balance book records (AMA 5077/1311 through 1323), so we can separate them from metal transactions. Table A5 lists the municipal transactions that changed the supply of guilder (account transactions). Table A5 also lists when the city moved metal in or out of the bank but did not change the guilder money supply (metal transactions). Combining these two transaction types gives the full accounting of the city's extraction of capital from the bank.

\section{Bullion}

After removing 1) loans and 2) transfers from receivers, the debit side of the Specie Kamer still contains some direct deposits that avoid the receivers. We lack a contemporaneous description of why some deposits were processed through receivers while others were not, but we think that bullion was directly deposited into the Specie Kamer while coins went through the receivers. To begin, the use of receiver accounting begins in the 1620 s, so the distinction predates receipts or the agio. Next, the direct deposits are far more likely to involve a remainder less than a guilder, and even less than a stuiver (1/20th of a guilder). In contrast, receivers see far more large round deposits. Table A6 measures this dramatic difference through the percent of deposit transactions by depository channel that fall into large round values or into odd values. Bullion tends 
towards odd values because it is valued by weight and fineness, so a piece of bullion would rarely hit exactly a round guilder value. In contrast, official coins carried assigned values denominated in stuivers: 0.05 guilder increments and almost all in 0.1 increments (Menno S. Polak, Historiografie en Economie van de "Muntchaos," De Muntproductie van de Republiek 16061795, Deel I (1998), NEHA, Amsterdam, pp. 67-101). The standard bulk unit for coins was a sack of 200, so round guilder values are common. Multiple sacks produce large values round to 100 guilders or even 1,000 guilders.

In practice, the difference looks like this. On July 20, 1688, Samuel Cohen made two deposits that were both credited to the same account (5077/113 f. 1491). With the receiver Arthur Woodward, Cohen deposited 2,400 guilders that could easily have been 4 sacks of silver rijders (a standard trade coin) at the ordinance value of 3 guilders per coin (5077/113 f. 1517). Through the Specie Kamer, Cohen deposited 6,873.25 guilders (5077/113 f. 1484). That sum is difficult to reach using standard coins if for no other reason than almost all Dutch coins were priced in even stuivers ( 0.1 increments). More importantly, we think the bullion-coin divide explains why Cohen made two deposits on the same day, for the pattern can be found on other days. For example, six days earlier, Cohen had deposited 11,073.075 guilders in the Specie Kamer and 3,675 guilders through a receiver $(5077 / 131$, ff. 1484, 1517).

Our interpretation has other support. In April and May 1668, the Specie Kamer debits surged, and our theory suggests that this is a period of open market purchases. The AWB's mint orders survive for that year, and simultaneous with the purchases, the bank sent large quantities of silver bullion (480,003 guilders worth) to the various mints from 27 April to 30 May (5077/1313). Table A7 reports the guilder value sent to each mint.

Unfortunately for our purposes, the AWB did not separate metal outflows into different accounts, so we use odd values as a proxy for bullion. While not perfect, a sort by odd-value versus round-value seems to reasonably mirror long-term behavior on the deposit side as seen in figure 5. Also, we know that the great run of June 1672 was not an open market operation. In that month, round values withdrawals (our proxy for coin) totaled 2.5 million guilders while oddvalues withdrawals (our proxy for bullion) totaled 0.3 million guilders. The monthly flow of these series is reported in Table A8. 


\section{Fee Ratios}

Having reconstructed withdrawals for our sample period, we calculated an average fee per year by dividing fee revenue by total withdrawals. Table A9 reports the numbers in ratio of fee revenue over metal outflows.

Fee revenue had to be constructed for the years 1666 to 1684, for the AWB reported total revenue. We adjusted revenue for the AWB's practice of counting interest due from the VOC as revenue and subsequently not counting the actual interest payments. Next we removed interest payments from the VOC (by Specie Kamer account) and from the Province of Holland (by metal) to get a remainder to proxy "withdrawal fee" revenue. The proxy overstates actual withdrawal fee revenue, for it also includes other minor fees like overdraft charges. We do not report revenue for the fiscal year 1673 because the bank replaced its regular revenue and expenses with a single 67,247 write down caused by the re-pricing of Russian coins held by the bank (van Dillen 1925: 746). 1677, 1682 and 1684 lack complete withdrawal information because of missing ledgers. The 1679 withdrawal numbers are low (fee ratio high) because we lack one Specie Kamer folio for that year.

1683 is the only year during the receipt regime for which we have revenue and withdrawals. The ratio is 0.67 percent, but it is a poor proxy for withdrawal fees. Under the new regime, one paid a receipt fee to rollover the option, so no metal need leave the bank. Also the bank began charging a transfer fee of 0.025 percent (van Dillen 1934: 84). We cannot separate these different revenue sources, so we can only state that fee revenue dropped to a low rate in the year receipts were adopted.

\section{VOC}

Table A10 considers the AWB as a creditor to the VOC in two ways: levels and flows. Column 1 reports the amount the VOC owed to the AWB in bank guilders. We calculate this amount using the bank's records. The VOC records do not identify creditors. Column 2 reports the level of the VOC's total debt in current guilders. The total debt is comprised of obligations of the company in general, obligations of each chamber, anticipations, bills of exchange, and miscellaneous creditors. Column 3 gives the AWB's share of the total and assumes an agio of 4.5 percent. 
While some years find the VOC owing 10 to 20 percent of its debt to the AWB, 15 out of 36 fiscal years closed with the company owing nothing to the bank. Levels suggest that in the VOC relied on the AWB as a substantial multi-year lender in and near the 1680s. Otherwise, the AWB was a long-term lender of little consequence.

To see the short-term credit story, we have reconstructed the amount the VOC borrowed from the AWB during each fiscal year (column 4). We do not report repayment, for we already know that often this debt was repaid within the year. Instead, we wonder how the VOC was using the AWB to facilitate operations during a fiscal year. Unfortunately, the VOC records do not tell us intra-year borrowing, so we cannot calculate the AWB's share of all short-term lending to the VOC.

We do know, however, some general measures of VOC activity, so we instead see what correlates with VOC borrowing from the AWB. Our approach is descriptive and seeks only the gentlest of inferences regarding why the VOC borrowed from the AWB. As a dependent variable, we have the amount of VOC borrowing from the AWB per fiscal year in bank guilders. For explanatory variables, we know the following in current guilders:

Two activities potentially creating demand for loans:

1. The total amount spent by the VOC in the Netherlands outfitting ships, paying interest, etc.

2. The amount of cash dividends paid out by the company to shareholders.

One activity potentially reducing the demand for loans

3. The total amount collected by the VOC from selling goods.

And a few VOC balance sheet items (levels) at the start of each fiscal year that might affect demand for AWB loans in the forthcoming year:

4. The trade good inventory

5. The cash and bank balances

6. Trade credits due to the VOC

7. The total external debt

We regressed AWB lending on these seven variables using OLS with no modifications, and the result is in the paper as table 4. Expenditures strongly and positively correlate with borrowing. They suggest a derived demand for AWB loans of 25 percent of total expenditures. In con- 
trast, Information about that year's sales revenue lacks any explanatory power. These results agree with the idea that the VOC was borrowing to outfit ships before the year's fleet returned from Asia.

Dividends appear of occasional consequence, and we cannot sort out why some dividends correlate with AWB borrowing while others do not.

Of the four start-of-year levels, the three assets (substitutes to AWB loans) do have negative coefficients. While not statistically significant, the inventory and credit due levels suggest notable effects. Starting cash appears of little import. Finally, the level of VOC debt at the start of a fiscal year gives little information regarding AWB loans.

In total, we feel that comparing AWB loan amounts to yearly VOC expenditures (Column 5) gets at the heart of the AWB-VOC credit relationship. While that share (Column 6) did vary, AWB loans became a routine, and often substantial, part of financing yearly ship outfitting.

\section{Interpolation of the agio}

The agio series was interpolated using a time series on the London price of a bill of exchange payable in Amsterdam (McCusker 1978, Table 2.8), quoted as bank schillings (i.e., 0.3 guilders) per pound sterling. The bill price series contains 179 monthly observations over the sample period, including 77 months for which there is no corresponding agio observation. A Kalman filter routine was used to fit a 3-month, bivariate VAR by maximum likelihood to all available observations on the agio and on the bill price. Interpolated values of the agio are the values returned by the Kalman smoother at the ML estimates.

The accuracy of this method was tested by simulations, in which a random selection of agio observations (excluding the 1672 and 1693 outlier periods) were removed from the sample and then estimated using the interpolation procedure described above. The standard error of the smoothed estimates of the agio ranges from about 22 basis points over the holdout sample (with a 5 percent probability of observations being allocated to holdout sample) to 35 basis points (with a 50 percent probability). These are smaller than sample standard deviation of the agio series (about 50 basis points; see Table 3), suggesting that the interpolation procedure is of value in estimating missing values of the agio. 


\section{Table A1. AWB Balance Sheet, 1666 to 1703, in Bank Guilders ${ }^{1}$}

\begin{tabular}{|c|c|c|c|c|c|c|c|c|c|}
\hline $\begin{array}{l}\text { End of } \\
\text { January }\end{array}$ & Total Balance & Metal Stock & $\begin{array}{r}\text { VOC } \\
\text { Principal }\end{array}$ & $\begin{array}{r}\text { VOC } \\
\text { Interest Due }\end{array}$ & $\begin{array}{r}\text { Amsterdam } \\
\text { Principal }\end{array}$ & Holland $^{2}$ & Misc. $^{3}$ & $\begin{array}{r}\text { Account } \\
\text { Balances }\end{array}$ & Capital \\
\hline 1666 & $10,057,240$ & $7,454,756$ & 300,000 & 1,925 & $2,072,898$ & 224,662 & 0 & $8,411,238$ & $1,646,002$ \\
\hline 1667 & $9,808,032$ & $6,904,522$ & 600,000 & 5,950 & $2,072,898$ & 224,662 & 0 & $8,137,198$ & $1,670,834$ \\
\hline 1668 & $7,916,122$ & $4,700,428$ & 900,000 & $8,311^{4}$ & $2,072,898$ & 224,662 & 9,823 & $6,202,978$ & $1,713,144$ \\
\hline 1669 & $7,851,084$ & $4,488,911$ & $1,000,000$ & 18,333 & $2,072,898$ & 224,662 & 46,281 & $6,078,661$ & $1,772,423$ \\
\hline 1670 & $7,166,504$ & $4,841,334$ & 0 & 0 & $2,072,898$ & 224,662 & 27,610 & $5,367,018$ & $1,799,486$ \\
\hline 1671 & $11,160,451$ & $8,862,891$ & 0 & 0 & $2,072,898$ & 224,662 & 0 & $9,355,574$ & $1,804,877$ \\
\hline 1672 & $9,056,487$ & $6,654,277$ & 100,000 & 0 & $2,072,898$ & 224,662 & 4,649 & $7,210,433$ & $1,846,054$ \\
\hline 1673 & $6,852,616$ & $3,664,117$ & 0 & 0 & $2,072,898$ & 224,662 & 890,940 & $4,933,701$ & $1,918,915$ \\
\hline 1674 & $8,366,142$ & $5,976,295$ & 0 & 0 & $2,072,898$ & 226,830 & 90,119 & $6,514,474$ & $1,851,668$ \\
\hline 1675 & $8,451,723$ & $5,944,943$ & 200,000 & 0 & $2,072,898$ & 226,830 & 7,052 & $6,587,691$ & $1,864,032$ \\
\hline 1676 & $7,071,631^{5}$ & $4,471,902$ & 300,000 & 0 & $2,072,898$ & 226,830 & 0 & $5,174,297$ & $1,897,334$ \\
\hline 1677 & $7,862,941$ & $4,747,706$ & 800,000 & 15,507 & $2,072,898$ & 226,830 & 0 & $5,924,194$ & $1,938,747$ \\
\hline 1678 & $7,226,068$ & $3,475,326$ & $1,400,000$ & 51,013 & $2,072,898$ & 226,830 & 0 & $5,229,008$ & $1,997,060$ \\
\hline 1679 & $7,545,572$ & $3,632,511$ & $1,600,000$ & 13,333 & $2,072,898$ & 226,830 & 0 & $5,488,900$ & $2,056,672$ \\
\hline 1680 & $10,069,553$ & $6,156,491$ & $1,600,000$ & 13,333 & $2,072,898$ & 226,830 & 0 & $7,950,340$ & $2,119,213$ \\
\hline 1681 & $10,444,657$ & $7,136,595$ & $1,000,000$ & 8,333 & $2,072,898$ & 226,830 & 0 & $8,277,109$ & $2,167,548$ \\
\hline 1682 & $8,741,257$ & $5,536,528$ & 900,000 & 5,000 & $2,072,898$ & 226,830 & 0 & $6,510,142$ & $2,231,115$ \\
\hline 1683 & $10,567,596$ & $7,595,133$ & 400,000 & 3,333 & $2,342,299$ & 226,830 & 0 & $8,295,978$ & $2,271,618$ \\
\hline 1684 & $9,990,534$ & $6,822,321$ & 400,000 & 5,199 & $2,536,184$ & 226,830 & 0 & $7,695,285$ & $2,295,249$ \\
\hline 1685 & $9,300,020$ & $6,096,968$ & 0 & 0 & $2,976,222$ & 226,830 & 0 & $6,959,229$ & $2,340,791$ \\
\hline 1686 & $9,860,991$ & $7,472,301$ & $1,100,000$ & 6,124 & $1,055,735$ & 226,830 & 0 & $9,813,776$ & 47,215 \\
\hline 1687 & $10,237,827$ & $7,913,428$ & $1,300,000$ & 29,604 & 767,965 & 226,830 & 0 & $10,175,964$ & 61,863 \\
\hline 1688 & $10,884,061$ & $9,946,553$ & 0 & 0 & 710,243 & 227,264 & 0 & $10,752,029$ & 132,032 \\
\hline 1689 & $12,864,189$ & $11,831,444$ & 0 & 0 & 805,481 & 227,264 & 0 & $12,714,692$ & 149,497 \\
\hline 1690 & $12,775,203$ & $11,742,458$ & 0 & 0 & 805,481 & 227,264 & 0 & $12,604,282$ & 170,921 \\
\hline 1691 & $13,569,830$ & $12,708,006$ & 0 & 0 & 634,560 & 227,264 & 0 & $13,557,117$ & 12,713 \\
\hline 1692 & $13,183,611$ & $12,321,787$ & 0 & 0 & 634,560 & 227,264 & 0 & $13,181,990$ & 1,620 \\
\hline 1693 & $13,559,192$ & $12,602,130$ & 0 & 0 & 729,798 & 227,264 & 0 & $13,524,659$ & 34,533 \\
\hline 1694 & $11,535,761$ & $10,377,152$ & 0 & 0 & 931,345 & 227,264 & 0 & $11,479,354$ & 56,407 \\
\hline 1695 & $12,108,018$ & $10,405,194$ & 400,000 & 0 & $1,075,560$ & 227,264 & 0 & $12,013,638$ & 94,380 \\
\hline 1696 & $10,332,717$ & $8,648,941$ & 0 & 0 & $1,456,512$ & 227,264 & 0 & $10,207,122$ & 125,595 \\
\hline 1697 & $10,412,947$ & $9,110,123$ & 0 & 0 & $1,075,560$ & 227,264 & 0 & $10,263,048$ & 149,899 \\
\hline 1698 & $15,386,685$ & $12,383,861$ & $1,500,000$ & 0 & $1,275,560$ & 227,264 & 0 & $15,233,928$ & 152,757 \\
\hline 1699 & $16,919,060$ & $13,716,236$ & 600,000 & 0 & $2,375,560$ & 227,264 & 0 & $16,750,540$ & 168,520 \\
\hline 1700 & $16,468,096$ & $13,365,272$ & 500,000 & 0 & $2,375,560$ & 227,264 & 0 & $16,284,849$ & 183,247 \\
\hline 1701 & $15,040,586$ & $12,037,762$ & 800,000 & 0 & $1,975,560$ & 227,264 & 0 & $14,830,152$ & 210,434 \\
\hline 1702 & $15,044,384$ & $11,541,561$ & $1,300,000$ & 0 & $1,975,560$ & 227,264 & 0 & $14,782,959$ & 261,425 \\
\hline 1703 & $12,908,349$ & $10,005,525$ & 700,000 & 0 & $1,975,560$ & 227,264 & 0 & $12,578,043$ & 330,306 \\
\hline
\end{tabular}


Source is authors' adjustment of van Dillen (1925, 741-762)

Notes for Table A1:

1. Holland's debt is in current guilders.

2. The 1666 total comprises a loan of 132,000 at 4 percent, one year's interest on that sum $(5,280)$, a loan of 84,836 at 4 percent, and 9 month's interest on that sum $(2,546)$. See AMA 5077/1311, folio 4. In 1674, Holland's debt was increased by 2,168 because of missed interest payments in 1673 (AMA 5077/1315, folio 4). An additional 434 in interest is considered due from Holland starting in 1688 (5077/1322, folio 16).

3. Miscellaneous includes negative balances of assayers, mint masters, an emergency loan in 1672, and other unspecified claims. All miscellaneous lending ends in 1676.

4. Miscellaneous includes negative balances of assayers, mint masters, an emergency loan in 1672, and other unspecified claims. All miscellaneous lending ends in 1676.

5. The 1676 metal stock and capital have been reduced by 30,000 each per a write-down not booked until 1677 (van Dillen 1925: 747-8; AMA 5077/1315, folios 1-2). 


\section{Table A3. AWB Ledgers and Folios}

By Half-Year Periods: $a=$ February to July, $b=$ August to January

Date Ledger Folios: Specie Kamer in Bold, Receiver Folios in Regular (kept in sequence by receiver)

\begin{tabular}{|c|c|c|c|c|c|c|c|c|c|c|c|}
\hline $1666 a$ & $5077 / 62$ & 147 & 1174 & 1391 & 149 & 151 & & & & & \\
\hline $1666 b$ & $5077 / 63$ & 1054 & 1233 & 1050 & 1052 & 1260 & & & & & \\
\hline $1667 a$ & $5077 / 64$ & 982 & 1149 & 1249 & 1387 & 984 & 986 & 988 & & & \\
\hline $1667 b$ & $5077 / 65$ & 982 & 1088 & 1144 & 1263 & 984 & 986 & 988 & & & \\
\hline $1668 a$ & $5077 / 66$ & $\begin{array}{l}1006 \\
1012\end{array}$ & 1082 & 1179 & 1238 & 1252 & 1276 & 1397 & 1528 & 1008 & 1010 \\
\hline $1668 b$ & $5077 / 67$ & 1010 & 1154 & 1474 & 1012 & 1018 & 1020 & & & & \\
\hline $1669 a$ & $5077 / 68$ & 1010 & 1203 & 1479 & 1012 & 1014 & 1016 & & & & \\
\hline $1669 b$ & $5077 / 69$ & 1010 & 1314 & 1012 & 1014 & 1330 & 1016 & 1353 & & & \\
\hline $1670 \mathrm{a}$ & $5077 / 70$ & 1008 & 1177 & 1220 & 1010 & 1328 & 1012 & 1129 & 1240 & 1014 & 1347 \\
\hline $1670 \mathrm{~b}$ & $5077 / 71$ & $\begin{array}{l}1008 \\
1172\end{array}$ & $\begin{array}{l}1060 \\
1416\end{array}$ & 1114 & 1262 & 1010 & 1250 & 1420 & 1012 & 1348 & 1014 \\
\hline $1671 \mathrm{a}$ & $5077 / 72$ & $\begin{array}{c}90 \\
1038\end{array}$ & $\begin{array}{l}1273 \\
1207\end{array}$ & 1375 & 1450 & 1494 & 1034 & 1077 & 1140 & 1036 & 1120 \\
\hline $1671 b$ & $5077 / 73$ & 1028 & 1142 & 1501 & 1030 & 1032 & 1034 & & & & \\
\hline $1672 \mathrm{a}$ & $5077 / 74$ & $\begin{array}{c}990 \\
1496\end{array}$ & $\begin{array}{l}1415 \\
1501\end{array}$ & $\begin{array}{l}1433 \\
1076\end{array}$ & $\begin{array}{l}1439 \\
1078\end{array}$ & $\begin{array}{l}1449 \\
1080\end{array}$ & 1455 & 1461 & 1465 & 1478 & 1488 \\
\hline $1672 b$ & $5077 / 75$ & 1044 & 1047 & 1046 & 1220 & 1048 & 1050 & & & & \\
\hline $1673 a$ & Missing & & & & & & & & & & \\
\hline $1673 b$ & $5077 / 76$ & $\begin{array}{c}1020 \\
722\end{array}$ & $\begin{array}{l}1082 \\
1062\end{array}$ & $\begin{array}{l}1158 \\
1116\end{array}$ & 1022 & 1024 & 1026 & 1032 & 1062 & 258 & 298 \\
\hline $1674 a$ & $5077 / 77$ & 878 & 1209 & 1303 & 880 & 882 & 884 & & & & \\
\hline $1674 b$ & $5077 / 78$ & 910 & 1114 & 1341 & 1446 & 912 & 914 & 916 & & & \\
\hline $1675 a$ & $5077 / 79$ & 952 & 1282 & 1467 & 954 & 956 & 958 & & & & \\
\hline $1675 b$ & $5077 / 80$ & 974 & 1217 & 976 & 978 & 980 & & & & & \\
\hline
\end{tabular}




\begin{tabular}{|c|c|c|c|c|c|c|c|c|c|c|c|}
\hline $1676 a$ & $5077 / 81$ & 1016 & 1018 & 1020 & 1022 & & & & & & \\
\hline $1676 \mathrm{~b}$ & $5077 / 82$ & 1042 & 1044 & 1046 & 1048 & & & & & & \\
\hline $1677 \mathrm{a}$ & Missing & & & & & & & & & & \\
\hline $1677 b$ & $5077 / 83$ & 1044 & 1494 & 1046 & 1048 & 1050 & & & & & \\
\hline $1678 \mathrm{a}$ & $5077 / 84$ & 1078 & 1452 & 1080 & 1082 & 1084 & & & & & \\
\hline $1678 b$ & $5077 / 85$ & 1058 & 1060 & 1062 & 1064 & & & & & & \\
\hline $1679 a$ & $5077 / 86$ & 1021 & 1022 & 1023 & 1024 & & & & & & \\
\hline $1679 b$ & $5077 / 87$ & 1008 & 1332 & 1421 & 1009 & 1010 & 1011 & & & & \\
\hline $1680 \mathrm{a}$ & $5077 / 88$ & 978 & 1024 & 1382 & 979 & 980 & 981 & & & & \\
\hline $1680 \mathrm{~b}$ & $5077 / 89$ & 1006 & 979 & 980 & 981 & & & & & & \\
\hline $1681 \mathrm{a}$ & $5077 / 90$ & 982 & 979 & 980 & 981 & & & & & & \\
\hline $1681 b$ & $5077 / 91$ & 982 & 979 & 980 & 981 & & & & & & \\
\hline $1682 \mathrm{a}$ & $5077 / 92$ & 981 & 979 & 1390 & 980 & 1396 & 949 & & & & \\
\hline $1682 b$ & Missing & & & & & & & & & & \\
\hline $1683 a$ & $5077 / 94$ & 990 & 1406 & 1564 & 988 & 1505 & 989 & 1052 & 1296 & 1351 & 1514 \\
\hline $1683 b$ & $5077 / 96$ & 990 & 1292 & 1337 & 1422 & 1519 & 988 & 994 & 989 & 1286 & 1463 \\
\hline $1684 a$ & $5077 / 98$ & $\begin{array}{c}\mathbf{9 9 0} \\
1567\end{array}$ & $\begin{array}{c}1277 \\
989\end{array}$ & $\begin{array}{l}1317 \\
1407\end{array}$ & $\begin{array}{l}\mathbf{1 3 6 0} \\
1512\end{array}$ & $\begin{array}{l}\mathbf{1 3 8 3} \\
1573\end{array}$ & 1411 & 1484 & 1585 & 988 & 1518 \\
\hline $1684 b$ & Missing & & & & & & & & & & \\
\hline $1685 a$ & $5077 / 101$ & $\begin{array}{c}\mathbf{9 9 0} \\
1453\end{array}$ & $\begin{array}{c}\mathbf{1 2 7 4} \\
989\end{array}$ & $\begin{array}{l}\mathbf{1 3 0 0} \\
1334\end{array}$ & $\begin{array}{l}\mathbf{1 3 4 4} \\
1427\end{array}$ & $\begin{array}{l}1402 \\
1484\end{array}$ & 1450 & 1500 & 1533 & 988 & 1330 \\
\hline $1685 b$ & $5077 / 103$ & $\begin{array}{c}\mathbf{9 9 0} \\
1296 \\
1508\end{array}$ & $\begin{array}{l}1299 \\
1317 \\
1531\end{array}$ & $\begin{array}{l}1335 \\
1459\end{array}$ & $\begin{array}{l}\mathbf{1 3 4 4} \\
1503\end{array}$ & $\begin{array}{l}1349 \\
1532\end{array}$ & $\begin{array}{c}1365 \\
989\end{array}$ & $\begin{array}{l}\mathbf{1 3 7 8} \\
1300\end{array}$ & $\begin{array}{l}1399 \\
1321\end{array}$ & $\begin{array}{l}1462 \\
1411\end{array}$ & $\begin{array}{c}988 \\
1470\end{array}$ \\
\hline $1686 a$ & $5077 / 105$ & $\begin{array}{c}\mathbf{9 9 0} \\
1492\end{array}$ & $\begin{array}{c}\mathbf{1 2 8 0} \\
989\end{array}$ & $\begin{array}{l}\mathbf{1 3 0 0} \\
1313\end{array}$ & $\begin{array}{l}\mathbf{1 3 3 4} \\
1408\end{array}$ & $\begin{array}{l}1390 \\
1471\end{array}$ & $\begin{array}{l}1451 \\
1494\end{array}$ & 1491 & 988 & 1275 & 1462 \\
\hline $1686 b$ & $5077 / 107$ & $\begin{array}{c}\mathbf{9 9 0} \\
1392\end{array}$ & $\begin{array}{c}1283 \\
989\end{array}$ & $\begin{array}{l}\mathbf{1 3 1 9} \\
1284\end{array}$ & $\begin{array}{l}\mathbf{1 3 7 8} \\
1310\end{array}$ & $\begin{array}{l}1437 \\
1335\end{array}$ & $\begin{array}{l}\mathbf{1 4 7 6} \\
1358\end{array}$ & $\begin{array}{c}988 \\
1369\end{array}$ & $\begin{array}{l}1303 \\
1402\end{array}$ & $\begin{array}{l}1339 \\
1470\end{array}$ & $\begin{array}{l}1366 \\
1492\end{array}$ \\
\hline
\end{tabular}




\begin{tabular}{|c|c|c|c|c|c|c|c|c|c|c|c|}
\hline \multirow[t]{3}{*}{$1687 \mathrm{a}$} & \multirow[t]{3}{*}{$5077 / 109$} & 990 & 1297 & \multirow{3}{*}{$\begin{array}{l}1354 \\
1491\end{array}$} & \multirow{3}{*}{$\begin{array}{c}1431 \\
989\end{array}$} & \multirow{3}{*}{$\begin{array}{l}\mathbf{1 4 9 6} \\
1283\end{array}$} & \multirow{3}{*}{$\begin{array}{c}988 \\
1303\end{array}$} & \multirow{3}{*}{$\begin{array}{l}1291 \\
1329\end{array}$} & \multirow{3}{*}{$\begin{array}{l}1322 \\
1380\end{array}$} & \multirow{3}{*}{$\begin{array}{l}1353 \\
1407\end{array}$} & \multirow{3}{*}{$\begin{array}{l}1376 \\
1445\end{array}$} \\
\hline & & 1413 & 1465 & & & & & & & & \\
\hline & & 1477 & 1497 & & & & & & & & \\
\hline \multirow[t]{3}{*}{$1687 b$} & $5077 / 111$ & 990 & 1312 & 1377 & 1462 & 1482 & 1498 & 1515 & 1527 & 988 & 1290 \\
\hline & & 1315 & 1347 & 1383 & 1412 & 989 & 1289 & 1301 & 1321 & 1345 & 1371 \\
\hline & & 1395 & 1413 & & & & & & & & \\
\hline \multirow[t]{2}{*}{$1688 \mathrm{a}$} & $5077 / 113$ & 990 & 1299 & 1326 & 1380 & 1429 & 1484 & 1537 & 988 & 1378 & 1450 \\
\hline & & 1511 & 989 & 1379 & 1432 & 1464 & 1489 & 1517 & 1534 & & \\
\hline \multirow[t]{3}{*}{$1688 b$} & $5077 / 115$ & 990 & 1314 & 1351 & 1403 & 1455 & 1487 & 1514 & 1540 & 988 & 1354 \\
\hline & & 1393 & 1420 & 989 & 1306 & 1338 & 1366 & 1388 & 1405 & 1416 & 1443 \\
\hline & & 1495 & & & & & & & & & \\
\hline \multirow[t]{2}{*}{$1689 a$} & $5077 / 117$ & 1171 & 1423 & 1450 & 1461 & 1493 & 1552 & 1596 & 1181 & 1176 & 1427 \\
\hline & & 1503 & 1564 & 1624 & & & & & & & \\
\hline \multirow[t]{2}{*}{$1689 b$} & $5077 / 119$ & 1171 & 1429 & 1476 & 1533 & 1581 & 1616 & 1640 & 1676 & 1181 & 1176 \\
\hline & & 1421 & 1439 & 1471 & 1519 & 1532 & & & & & \\
\hline \multirow[t]{2}{*}{$1690 \mathrm{a}$} & $5077 / 121$ & 1171 & 1419 & 1440 & 1463 & 1502 & 1542 & 1591 & 1624 & 1664 & 1181 \\
\hline & & 1176 & 1643 & & & & & & & & \\
\hline \multirow[t]{2}{*}{$1690 \mathrm{~b}$} & $5077 / 123$ & 1171 & 1421 & 1439 & 1463 & 1499 & 1540 & 1575 & 1609 & 1651 & 1695 \\
\hline & & 1176 & 1454 & 1527 & 1562 & 1581 & 1181 & 1259 & 1555 & 1586 & \\
\hline \multirow[t]{2}{*}{$1691 \mathrm{a}$} & $5077 / 124$ & 1171 & 1427 & 1440 & 1464 & 1485 & 1511 & 1549 & 1573 & 1622 & 1675 \\
\hline & & 1715 & 1176 & 1632 & 1692 & 1181 & 1603 & & & & \\
\hline \multirow[t]{2}{*}{$1691 b$} & $5077 / 126$ & 1171 & 1448 & 1478 & 1521 & 1574 & 1620 & 1668 & 1709 & 1739 & 1176 \\
\hline & & 1466 & 1547 & 1676 & 1181 & 1487 & 1563 & 1657 & & & \\
\hline \multirow[t]{2}{*}{$1692 \mathrm{a}$} & $5077 / 128$ & 1171 & 1461 & 1490 & 1512 & 1547 & 1583 & 1623 & 1667 & 1698 & 1728 \\
\hline & & 1176 & 1581 & 1181 & 1492 & 1632 & 1719 & & & & \\
\hline \multirow[t]{2}{*}{$1692 b$} & $5077 / 130$ & 1171 & 1467 & 1498 & 1545 & 1586 & 1631 & 1675 & 1734 & 1766 & 1176 \\
\hline & & 1488 & 1635 & 1683 & 1758 & 1181 & 1569 & 1622 & 1674 & 1785 & \\
\hline \multirow[t]{3}{*}{$1693 a$} & $5077 / 132$ & 1171 & 1486 & 1504 & 1532 & 1559 & 1585 & 1619 & 1639 & 1654 & 1673 \\
\hline & & 1675 & 1705 & 1728 & 1772 & 1793 & 1176 & 1616 & 1750 & 1181 & 1609 \\
\hline & & 1756 & & & & & & & & & \\
\hline \multirow[t]{2}{*}{$1693 b$} & $5077 / 134$ & 1171 & 1444 & 1465 & 1501 & 1527 & 1576 & 1640 & 1686 & 1176 & 1554 \\
\hline & & 1655 & 1181 & 1562 & 1637 & & & & & & \\
\hline \multirow[t]{2}{*}{$1694 a$} & $5077 / 136$ & 1171 & 1443 & 1464 & 1505 & 1540 & 1585 & 1628 & 1687 & 1732 & 1776 \\
\hline & & 1176 & 1689 & 1181 & 1705 & & & & & & \\
\hline $1694 b$ & $5077 / 138$ & 1171 & 1447 & 1481 & 1530 & 1601 & 1653 & 1721 & 1176 & 1181 & 1182 \\
\hline
\end{tabular}




\begin{tabular}{|c|c|c|c|c|c|c|c|c|c|c|c|}
\hline $1695 \mathrm{a}$ & $5077 / 140$ & $\begin{array}{l}\mathbf{1 1 7 1} \\
1181\end{array}$ & 1451 & 1475 & 1517 & 1564 & 1610 & 1679 & 1760 & 1799 & 1176 \\
\hline $1695 b$ & $5077 / 142$ & $\begin{array}{l}\mathbf{1 1 7 1} \\
1612\end{array}$ & $\begin{array}{l}1454 \\
1181\end{array}$ & 1487 & 1535 & 1599 & 1673 & 1747 & 1797 & 1176 & 1562 \\
\hline $1696 a$ & $5077 / 143$ & $\begin{array}{l}\mathbf{1 1 7 1} \\
1515\end{array}$ & $\begin{array}{l}1465 \\
1598\end{array}$ & $\begin{array}{l}\mathbf{1 5 0 1} \\
1745\end{array}$ & $\begin{array}{l}\mathbf{1 5 4 8} \\
1181\end{array}$ & $\begin{array}{l}\mathbf{1 6 0 7} \\
1533\end{array}$ & $\begin{array}{l}1662 \\
1695\end{array}$ & 1720 & 1765 & 1813 & 1176 \\
\hline $1696 b$ & $5077 / 145$ & $\begin{array}{l}1171 \\
1181\end{array}$ & $\begin{array}{l}1478 \\
1588\end{array}$ & $\begin{array}{l}1512 \\
1699\end{array}$ & 1581 & 1645 & 1730 & 1829 & 1176 & 1720 & 1833 \\
\hline
\end{tabular}

\begin{tabular}{|c|c|c|c|c|c|c|c|c|c|c|c|}
\hline $1697 \mathrm{a}$ & $5077 / 146$ & 1171 & 1481 & 1536 & 1589 & 1645 & 1704 & 1764 & 1176 & 1482 & 1590 \\
\hline & & 1674 & 1725 & 1784 & 1181 & 1469 & 1573 & 1650 & 1744 & & \\
\hline
\end{tabular}

$1697 \mathrm{~b}$ Missing

$\begin{array}{llllllllllll}1698 \mathrm{a} & 5077 / 148 & \mathbf{1 1 7 1} & \mathbf{1 4 0 5} & \mathbf{1 5 2 3} & \mathbf{1 5 9 3} & \mathbf{1 6 8 8} & \mathbf{1 7 6 8} & 1176 & 1664 & 1784 & 1181\end{array}$

$1594 \quad 1735$

$\begin{array}{llllllllllll}1698 b & 5077 / 150 & \mathbf{1 1 7 1} & \mathbf{1 4 7 6} & \mathbf{1 5 5 6} & \mathbf{1 6 7 6} & \mathbf{1 8 1 5} & 1176 & 1505 & 1560 & 1619 & 1666 \\ & & 1761 & 1860 & 1181 & 1487 & 1577 & 1693 & 1770 & 1902 & & \end{array}$

$\begin{array}{rlllllllllll}1699 a & 5077 / 152 & \mathbf{1 1 7 1} & \mathbf{1 5 0 4} & \mathbf{1 5 3 3} & \mathbf{1 5 9 6} & \mathbf{1 6 6 3} & \mathbf{1 7 4 4} & \mathbf{1 8 0 2} & \mathbf{1 8 4 2} & 1176 & 1516 \\ & & 1595 & 1674 & 1785 & 1849 & 1181 & 1541 & 1645 & 1812 & \end{array}$

\begin{tabular}{|c|c|c|c|c|c|c|c|c|c|c|c|}
\hline \multirow[t]{2}{*}{$1699 b$} & $5077 / 154$ & 1171 & 1484 & 1537 & 1595 & 1689 & 1807 & 1176 & 1513 & 1588 & 1624 \\
\hline & & 1655 & 1730 & 1843 & 1181 & 1478 & 1502 & 1576 & 1704 & 1741 & 1824 \\
\hline
\end{tabular}

\begin{tabular}{|c|c|c|c|c|c|c|c|c|c|c|}
\hline \multirow[t]{2}{*}{$1700 \mathrm{a}$} & \multirow[t]{2}{*}{$5077 / 156$} & 1271 & 1612 & 1657 & 1707 & 1779 & 1885 & 1961 & 1276 & 1601 \\
\hline & & 1684 & 1726 & 1871 & 1914 & 1281 & 1590 & 1637 & 1739 & 1917 \\
\hline
\end{tabular}

1700b Missing

$\begin{array}{llllllllllll}1701 \mathrm{a} & 5077 / 158 & \mathbf{1 2 7 1} & \mathbf{1 6 5 9} & \mathbf{1 7 3 4} & \mathbf{1 8 2 9} & \mathbf{1 9 3 9} & \mathbf{2 0 0 2} & 1276 & 1597 & 1700 & 1743 \\ & & 1799 & 1895 & 1967 & 2020 & 1281 & 1607 & 1622 & 1643 & 1665 & 1719 \\ & & 1810 & 1872 & 1946 & 2003 & & & & & & \end{array}$

$\begin{array}{llllllllllll}1701 \mathrm{~b} & 5077 / 160 & \mathbf{1 2 7 1} & \mathbf{1 6 2 9} & \mathbf{1 6 7 0} & \mathbf{1 7 3 7} & \mathbf{1 8 0 5} & \mathbf{1 8 7 8} & \mathbf{2 0 1 1} & 1276 & 1601 & 1609 \\ & & 1624 & 1712 & 1801 & 1932 & 1281 & 1639 & 1733 & 1859 & 1960 & \end{array}$

$\begin{array}{lllllllll}1624 & 1712 & 1801 & 1932 & 1281 & 1639 & 1733 & 1859 & 1960\end{array}$

$\begin{array}{llllllllllll}1702 \mathrm{a} & 5077 / 162 & \mathbf{1 2 7 1} & \mathbf{1 6 2 7} & \mathbf{1 6 9 1} & \mathbf{1 7 7 9} & \mathbf{1 8 4 8} & \mathbf{1 9 3 5} & 1276 & 1647 & 1704 & 1825 \\ & & 1928 & 1281 & 1630 & 1685 & 1765 & 1847 & 1983 & & & \end{array}$

$\begin{array}{lllllllllll}1702 \mathrm{~b} & 5077 / 164 & 1371 & 1732 & 1785 & \mathbf{1 8 6 6} & \mathbf{1 9 3 4} & 2003 & 1376 & 1916 & 1381\end{array}$ 
Table A4. Deduced VOC Loans

\begin{tabular}{|c|c|c|c|c|c|}
\hline \multicolumn{2}{|l|}{ Loans } & & \multicolumn{2}{|c|}{ Repayments } & \multirow{2}{*}{$\begin{array}{l}\text { Internal Rate } \\
\text { of Return }\end{array}$} \\
\hline Date & Amount & & Date & Amount & \\
\hline 7-Jul-71 & 200,000 & $\rightarrow$ & $10-$ Sep-71 & $201,446.20$ & $4.06 \%$ \\
\hline 17-Jul-71 & 400,000 & $\rightarrow$ & 9-Sep-71 & $402,410.38$ & $4.07 \%$ \\
\hline 24-Jul-71 & 300,000 & $\rightarrow$ & 11-Sep-71 & $301,643.75$ & $4.08 \%$ \\
\hline 4-Aug-71 & 200,000 & $\rightarrow$ & 610576 & $200,861.50$ & $4.03 \%$ \\
\hline 9-Jan-72 & 100,000 & & & & \\
\hline $8-F e b-72$ & 100,000 & $\rightarrow$ & 9-Mar-72 & $200,800.00$ & $3.24 \%$ \\
\hline 13-Nov-74 & 100,000 & $\rightarrow$ & 4-Dec-74 & $200,942.45$ & $4.10 \%$ \\
\hline 13-Nov-74 & 300,000 & $\rightarrow$ & 2-Apr-75 & $203,777.70$ & $5.79 \%{ }^{1}$ \\
\hline 10-Jan-75 & 300,000 & $\rightarrow$ & 11-Jan-75 & $300,000.00$ & \\
\hline 9-Jul-75 & 150,000 & & & & \\
\hline 13-Aug-75 & 200,000 & & & & \\
\hline 28-Aug-75 & 200,000 & & & & \\
\hline 7-Sep-75 & 100,000 & $\rightarrow$ & 19-Oct-75 & $654,710.90$ & $3.97 \%$ \\
\hline 18-Sep-75 & 100,000 & & & & \\
\hline $3-O c t-75$ & 100,000 & & & & \\
\hline 4-Oct-75 & 100,000 & & & & \\
\hline 9-Oct-75 & 100,000 & $\rightarrow$ & 24-Oct-75 & $401,022.30$ & $4.06 \%$ \\
\hline 31-Jan-83 & $403,333^{2}$ & $\rightarrow$ & $4 / 2 / 83$ & $101,533.33$ & $4.19 \%$ \\
\hline & & & $4 / 2 / 83$ & $203,066.65$ & $4.19 \%$ \\
\hline & & & $4 / 2 / 83$ & $101,533.33$ & $4.19 \%$ \\
\hline $4 / 16 / 83$ & 200,000 & $\rightarrow$ & $11 / 25 / 83$ & $204,644.45$ & $3.80 \%$ \\
\hline $5 / 13 / 83$ & 100,000 & $\rightarrow$ & $11 / 25 / 83$ & $102,088.80$ & $3.89 \%$ \\
\hline
\end{tabular}




\begin{tabular}{|c|c|c|c|c|c|}
\hline $6 / 18 / 83$ & 100,000 & $\rightarrow$ & $11 / 25 / 83$ & $101,744.35$ & $3.98 \%$ \\
\hline $7 / 14 / 83$ & 50,000 & $\rightarrow$ & $11 / 25 / 83$ & $50,727.73$ & $3.96 \%$ \\
\hline $7 / 20 / 83$ & 50,000 & $\rightarrow$ & $11 / 25 / 83$ & $50,677.78$ & $3.87 \%$ \\
\hline $8 / 23 / 83$ & 50,000 & $\rightarrow$ & $11 / 25 / 83$ & $50,511.10$ & $3.97 \%$ \\
\hline $8 / 31 / 83$ & 100,000 & $\rightarrow$ & $11 / 25 / 83$ & $100,944.48$ & $4.01 \%$ \\
\hline $10 / 26 / 83$ & 100,000 & $\rightarrow$ & $12 / 3 / 83$ & $100,400.00$ & $3.84 \%$ \\
\hline $11 / 1 / 83$ & 100,000 & & & & \\
\hline $11 / 9 / 83$ & 50,000 & & & & \\
\hline $11 / 12 / 83$ & 100,000 & & & & \\
\hline $11 / 15 / 83$ & 100,000 & $\rightarrow$ & $12 / 1 / 83$ & $350,816.65$ & $3.92 \%$ \\
\hline $9 / 13 / 83$ & 100,000 & & & & \\
\hline $10 / 5 / 83$ & 100,000 & & & & \\
\hline $10 / 12 / 83$ & 100,000 & & & & \\
\hline $10 / 14 / 83$ & 100,000 & $\rightarrow$ & $1 / 31 / 84^{3}$ & $405,199.00$ & $3.97 \%$ \\
\hline
\end{tabular}

Source: Authors' analysis.

\section{Notes}

1. De Korte (1984: 66) suggests that the VOC offered 6 percent on anticipations in 1674.

2. Uses the bank's record of debt due at the start of fiscal year 1683 .

3. Used the bank's record of debt due at the end of fiscal year 1684. 


\section{Table A5. Municipal Capital Extractions and Injections}

\section{$\underline{\text { Municipal Capital Extractions }}$}

\begin{tabular}{|c|c|c|c|c|}
\hline Date & Type & Bank Guilders & Current Guilder & Agio Used \\
\hline $5 / 30 / 82$ & Account & $20,000.00$ & $20,850.00$ & $41 / 4$ \\
\hline 14-Jan-83 & Metal & $249,400.50$ & $260,000.00$ & $41 / 4$ \\
\hline $10-F e b-83$ & Metal & $143,885.00$ & $150,000.00$ & $41 / 4^{1}$ \\
\hline 26-Jan-84 & Metal & $50,000.00$ & $52,125.00$ & $41 / 4^{1}$ \\
\hline 1-Mar-84 & Metal & $50,000.00$ & $52,062.50$ & $41 / 8^{1}$ \\
\hline 2-May-84 & Metal & $96,154.00$ & $100,000.00$ & $4^{1}$ \\
\hline 26-Oct-84 & Metal & $150,000.00$ & $156,187.50$ & $41 / 8^{1}$ \\
\hline 11-Jan-85 & Metal & $143,885.00$ & $150,000.00$ & $41 / 4^{1}$ \\
\hline $14-F e b-85$ & Metal & $120,863.30$ & $126,000.00$ & $41 / 4$ \\
\hline 13-Jul-85 & Metal & $47,961.65$ & $50,000.00$ & $41 / 4$ \\
\hline 28-Jul-85 & Metal & $47,961.65$ & $50,000.00$ & $41 / 4$ \\
\hline 28-Aug-85 & Metal & $95,923.30$ & $100,000.00$ & $41 / 4$ \\
\hline $15-N o v-85$ & Metal & $47,961.65$ & $50,000.00$ & $41 / 4$ \\
\hline 7-Dec-85 & Metal & $59,632.60$ & $62,167.00$ & $41 / 4$ \\
\hline 19-Feb-87 & Metal & $57,142.85$ & $60,000.00$ & 5 \\
\hline 7-Apr-88 & Metal & $95,238.10$ & $100,000.00$ & 5 \\
\hline 23-Jan-93 & Metal & $95,238.10$ & $100,000.00$ & 5 \\
\hline 4-Jun-93 & Metal & $142,500.00$ & $150,000.00$ & $55 / 19^{2}$ \\
\hline 30-Oct-93 & Metal & $59,047.60$ & $62,000.00$ & 5 \\
\hline 25-Feb-94 & Metal & $48,976.00$ & $51,458.00$ & 5 \\
\hline 20-Jul-94 & Metal & $95,238.00$ & $100,000.00$ & 5 \\
\hline 17-Feb-95 & Metal & $95,238.00$ & $100,000.00$ & 5 \\
\hline 8-Nov-95 & Metal & $95,238.00$ & $100,000.00$ & 5 \\
\hline 11-Jan-96 & Metal & $190,476.00$ & $200,000.00$ & 5 \\
\hline 18-Dec-97 & Account & $100,000.00$ & & \\
\hline 14-Jan-98 & Account & $100,000.00$ & & \\
\hline 28-Oct-98 & Account & $100,000.00$ & & \\
\hline 6-Nov-98 & Account & $200,000.00$ & & \\
\hline 8-Dec-98 & Account & $200,000.00$ & & \\
\hline 25-Nov-98 & Account & $300,000.00$ & & \\
\hline 23-Dec-98 & Account & $300,000.00$ & & \\
\hline 3-Mar-99 & Account & $100,000.00$ & & \\
\hline 18-Mar-99 & Account & $100,000.00$ & & \\
\hline 18-Mar-02 & Metal & $95,522.40$ & $100,000.00$ & $411 / 16$ \\
\hline
\end{tabular}


Table A5 Continued

$\underline{\text { Municipal Capital Injections }}$

\begin{tabular}{|c|c|c|c|c|}
\hline Date & Type & Bank Guilder & Current Guilder & Agio \\
\hline 12-Jun-86 & Metal & $191,847.00$ & $200,000.00$ & $41 / 4$ \\
\hline 19-Jul-86 & Metal & $95,923.00$ & $100,000.00$ & $41 / 4$ \\
\hline 23-Mar-87 & Metal & $57,142.85$ & $60,000.00$ & 5 \\
\hline 26-Aug-87 & Metal & $28,571.45$ & $30,000.00$ & 5 \\
\hline 4-Sep-87 & Metal & $28,571.45$ & $30,000.00$ & 5 \\
\hline 18-Apr-96 & Metal & $190,476.00$ & $200,000.00$ & 5 \\
\hline 1-Sep-96 & Metal & $190,476.00$ & $200,000.00$ & 5 \\
\hline 28-Mar-99 & Account & $200,000.00$ & & \\
\hline 6-Mar-99 & Metal & $100,000.00$ & $105,000.00$ & 5 \\
\hline 8-Apr-00 & Account & $400,000.00$ & & \\
\hline
\end{tabular}

Sources: AMA 5077/1311 through 1323.

Notes:

1. Imputed from bank guilders (5077/1321 f 7) and current guilders (5077/1322 loose insert).

2. Coins removed in sacks worth 600 current booked at 570 bank: likely driegulden. 


\section{Table A6. Large Value and Odd Value Deposits 1666 to 1703}

\begin{tabular}{|c|c|c|}
\hline & Specie Kamer & Receiver \\
\hline & Direct Debits ${ }^{1}$ & Debits \\
\hline Total Deposit Transactions & 3,686 & 17,771 \\
\hline \multicolumn{3}{|c|}{ Share of Deposits with guilder values that are } \\
\hline \multicolumn{3}{|c|}{$\begin{array}{l}\text { Share of Deposits with guilder values that are } \\
\text { Odd Values: }\end{array}$} \\
\hline With a Partial Guilder & $81.6 \%$ & $7.4 \%$ \\
\hline $\begin{array}{l}\text { With Partial Stuiver } \\
\left(1 / 20^{\text {th }} \text { of a guilder }\right)\end{array}$ & $10.3 \%$ & $0.5 \%$ \\
\hline
\end{tabular}

Source: Authors' calculation.

Notes

1. Excludes loan transactions, receiver transfers, and expenditures.

Table A7. AWB Mint Operations, April and May 1668

Guilder Value of Silver Bullion Sent to Various Mint

\begin{tabular}{|c|c|c|c|c|c|}
\hline Mint & 27-Apr & 1-May & 8-May & 14-May & 30-May \\
\hline Gelderland & $22,471.70$ & & $28,986.25$ & & $27,030.40$ \\
\hline Holland & $30,284.85$ & & $30,105.00$ & & $27,837.75$ \\
\hline West-Friesland & $23,091.80$ & & $29,123.60$ & & \\
\hline Utrecht & & $25,394.55$ & & $27,890.45$ & $26,278.85$ \\
\hline Friesland & & & & & $27,419.17$ \\
\hline Overijssel & & $23,877.80$ & & & \\
\hline Deventer & & $26,306.85$ & & & \\
\hline Kampen & & $24,396.55$ & & & \\
\hline Zwolle City & $24,116.85$ & & $27,586.30$ & & $27,804.95$ \\
\hline Total & $99,965.20$ & $99,975.75$ & $115,801.15$ & $27,890.45$ & $136,371.12$ \\
\hline Grand Total & $480,003.67$ & & & & \\
\hline
\end{tabular}

Source: AMA 5077/1313 


\section{Table A8. Monthly Flows: 1666 to 1703 in Bank Guilders}

Guilder Creation by Metal Inflows

"Coin Deposits"

Feb-66

Mar-66

Apr-66

May-66

Jun-66

Jul-66

Aug-66

Sep-66

Oct-66

Nov-66

Dec-66

Jan-67

Feb-67

Mar-67

Apr-67

May-67

Jun-67

Jul-67

Aug-67

Sep-67

Oct-67

Nov-67

Dec-67

Jan-68

Feb-68

Mar-68

Apr-68

May-68

Jun-68

Jul-68

Aug-68

Sep-68

Oct-68

Nov-68

Dec-68

Jan-69

Feb-69

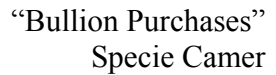

$42,281.95$

$17,631.75$

$55,413.20$

$92,164.03$

$66,628.95$

$134,581.98$

$269,442.73$

$181,391.53$

$6,063.40$

$11,344.80$

$1,723.10$

0.00

$5,666.95$

$3,911.75$

$43,451.53$

$20,656.10$

$9,303.00$

$9,870.30$

$1,000.00$

$12,679.50$

$2,060.50$

$14,537.35$

$1,074.50$

$5,775.70$

$35,867.35$

$8,260.00$

$10,744.00$

$7,128.40$

$5,548.90$

$19,091.50$

23,396.00

$12,941.50$

$7,259.80$

$13,627.60$

$14,407.15$

$11,376.50$

$39,286.20$
Specie Camer
0.00

0.00

$346,000.00$

$127,501.60$

$30,000.00$

$100,000.00$

$1,223.75$

0.00

0.00

0.00

0.00

0.00

$12,000.00$

$19,223.10$

$9,863.75$

$17,898.10$

$13,238.55$

$30,300.38$

$12,000.00$

$42,073.90$

0.00

$12,000.00$

$12,000.00$

0.00

0.00

$6,000.00$

$330,701.80$

$1,437,506.25$

$82,176.18$

$61,236.20$

$34,166.17$

$5,810.63$

$44,632.75$

$44,419.25$

0.00

$2,391.80$

0.00

Guilder Destruction by Metal Outflows

"Coin Withdrawals"

Round Values

$12,060.00$

$421,942.00$

$227,226.00$

$49,448.00$

833.00

$199,040.00$

$45,690.00$

$85,368.00$

$93,501.00$

$19,497.00$

$97,174.00$

$84,506.00$

$2,516.00$

$21,928.00$

$108,923.00$

$146,668.00$

$22,705.00$

$32,217.00$

$79,980.00$

$189,302.00$

$275,652.00$

$183,364.00$

$366,740.00$

$47,486.00$

$188,989.00$

$303,322.00$

$299,259.00$

$300,638.00$

$68,993.00$

$93,215.00$

$22,006.00$

$13,241.00$

$56,306.00$

$183,430.00$

$52,315.00$

42,000.00

$2,030.00$
"Bullion Sales" Odd Values

$17,726.88$

$15,030.28$

$105,405.70$

$125,898.75$

$7,413.03$

$66,083.47$

$19,349.83$

$15,278.05$

$13,460.00$

$12,904.00$

$105,545.35$

209,289.35

$31,667.90$

$119,202.98$

$156,628.80$

$57,984.18$

$44,185.53$

$72,909.75$

$27,386.80$

$107,987.45$

$74,613.98$

$340,681.90$

$13,159.95$

$36,121.00$

$76,232.75$

$77,171.25$

$139,993.30$

$147,324.68$

$90,181.73$

$99,446.75$

$30,366.63$

$38,153.17$

$45,533.77$

$31,601.70$

$12,496.25$

$18,943.45$

$14,882.90$ 


\begin{tabular}{|c|c|c|c|c|}
\hline Mar-69 & $28,162.10$ & $6,000.00$ & $3,772.00$ & $19,579.40$ \\
\hline Apr-69 & $5,600.00$ & $6,000.00$ & $17,290.00$ & $76,818.15$ \\
\hline May-69 & $14,670.00$ & $18,000.00$ & $8,829.00$ & $23,639.25$ \\
\hline Jun-69 & 305.50 & $20,610.70$ & $14,123.00$ & $8,238.33$ \\
\hline Jul-69 & $39,348.20$ & $15,564.70$ & $27,376.00$ & $21,568.05$ \\
\hline Aug-69 & $67,135.30$ & $18,000.00$ & $5,887.00$ & $9,013.05$ \\
\hline Sep-69 & $53,504.00$ & $73,726.60$ & $5,889.00$ & $7,547.40$ \\
\hline Oct-69 & $36,889.35$ & 0.00 & $65,291.00$ & $15,060.60$ \\
\hline Nov-69 & $100,741.45$ & $2,387.50$ & $27,079.00$ & $137,058.65$ \\
\hline Dec-69 & $294,380.30$ & $3,888.15$ & $50,335.00$ & $23,614.15$ \\
\hline Jan-70 & $17,923.85$ & $76,000.00$ & $24,009.00$ & $1,659.00$ \\
\hline Feb-70 & $108,314.75$ & $25,748.05$ & 840.00 & $5,013.75$ \\
\hline Mar-70 & $79,802.30$ & $45,520.48$ & $5,179.00$ & $12,531.00$ \\
\hline Apr-70 & $279,390.38$ & $101,164.38$ & $40,689.00$ & $17,844.63$ \\
\hline May-70 & $200,993.00$ & $483,741.45$ & $125,735.00$ & $10,910.50$ \\
\hline Jun-70 & $125,639.55$ & $148,622.20$ & $11,004.00$ & $16,772.88$ \\
\hline Jul-70 & $121,593.10$ & 0.00 & $4,432.00$ & $7,919.05$ \\
\hline Aug-70 & $139,628.25$ & $815,231.20$ & $8,283.00$ & $3,355.50$ \\
\hline Sep-70 & $137,260.03$ & $1,415,986.48$ & $257,001.00$ & $573,082.22$ \\
\hline Oct-70 & $91,050.75$ & $229,519.45$ & $75,786.00$ & $26,545.10$ \\
\hline Nov-70 & $74,448.15$ & $131,008.00$ & $91,176.00$ & $21,786.48$ \\
\hline Dec-70 & $121,171.35$ & $139,721.88$ & $148,987.00$ & $30,581.00$ \\
\hline Jan-71 & $243,924.75$ & $128,101.30$ & $52,038.00$ & $7,705.35$ \\
\hline Feb-71 & $277,492.55$ & $59,626.55$ & $2,505.00$ & $7,560.00$ \\
\hline Mar-71 & $293,073.40$ & $2,981.40$ & $18,665.00$ & 844.50 \\
\hline Apr-71 & $114,742.98$ & 0.00 & $129,335.00$ & $62,673.20$ \\
\hline May-71 & 274.00 & 842.70 & $90,409.00$ & $70,272.75$ \\
\hline Jun-71 & $28,717.65$ & $5,000.00$ & $428,959.00$ & $183,927.55$ \\
\hline Jul-71 & 0.00 & 0.00 & $644,761.00$ & $54,174.80$ \\
\hline Aug-71 & $6,006.30$ & 751.25 & $301,470.00$ & $9,447.50$ \\
\hline Sep-71 & $32,144.80$ & $1,194.25$ & $436,628.00$ & $211,452.98$ \\
\hline Oct-71 & 0.00 & 0.00 & $521,353.00$ & $8,430.00$ \\
\hline Nov-71 & $2,100.00$ & $11,378.60$ & $165,363.00$ & $52,643.20$ \\
\hline Dec-71 & $3,005.00$ & $31,694.72$ & $22,267.00$ & $10,776.00$ \\
\hline Jan-72 & $6,608.35$ & $94,975.90$ & $7,526.00$ & $3,357.75$ \\
\hline Feb-72 & $28,985.90$ & 0.00 & $31,200.00$ & $7,587.00$ \\
\hline Mar-72 & $8,840.00$ & 362.40 & $2,752.00$ & $43,275.45$ \\
\hline Apr-72 & $17,807.80$ & $1,977.42$ & $4,243.00$ & $7,554.00$ \\
\hline May-72 & $61,561.40$ & $492,991.48$ & 840.00 & $16,087.50$ \\
\hline Jun-72 & $88,319.22$ & $2,205.00$ & $2,478,372.00$ & $291,351.73$ \\
\hline Jul-72 & $184,624.65$ & $124,543.08$ & $497,630.00$ & $28,198.90$ \\
\hline Aug-72 & $36,767.85$ & 900.00 & $44,475.00$ & $1,160.65$ \\
\hline Sep-72 & $60,398.10$ & $32,908.30$ & $68,234.00$ & $20,114.50$ \\
\hline
\end{tabular}




\begin{tabular}{|c|c|c|c|c|}
\hline Oct-72 & $15,109.70$ & $141,521.70$ & $3,807.00$ & $10,978.90$ \\
\hline Nov-72 & $33,357.90$ & 0.00 & $17,870.00$ & $6,684.00$ \\
\hline Dec-72 & $19,019.50$ & $2,422.05$ & $3,844.00$ & $5,995.50$ \\
\hline Jan-73 & 931.40 & $81,112.15$ & $13,683.00$ & $11,762.25$ \\
\hline \multicolumn{5}{|l|}{ Feb-73 } \\
\hline \multicolumn{5}{|l|}{ Mar-73 } \\
\hline \multicolumn{5}{|l|}{ Apr-73 } \\
\hline \multicolumn{5}{|l|}{ May-73 } \\
\hline \multicolumn{5}{|l|}{ Jun-73 } \\
\hline \multicolumn{5}{|l|}{ Jul-73 } \\
\hline Aug-73 & $19,496.50$ & $46,196.25$ & 0.00 & $7,985.15$ \\
\hline Sep-73 & $161,096.95$ & $222,601.32$ & $1,695.00$ & 0.00 \\
\hline Oct-73 & $198,788.75$ & $272,967.28$ & 0.00 & 0.00 \\
\hline Nov-73 & $95,726.95$ & $129,162.38$ & 0.00 & 0.00 \\
\hline Dec-73 & $17,608.30$ & $132,844.53$ & $2,460.00$ & $6,897.50$ \\
\hline Jan-74 & $3,007.00$ & $148,456.25$ & $6,771.00$ & $16,868.25$ \\
\hline Feb-74 & $37,689.65$ & $6,380.60$ & $2,231.00$ & $5,937.00$ \\
\hline Mar-74 & 825.30 & $33,477.60$ & $3,432.00$ & $5,955.00$ \\
\hline Apr-74 & $3,468.70$ & $10,773.95$ & $29,706.00$ & $7,582.38$ \\
\hline May-74 & $1,747.30$ & $31,773.50$ & $175,013.00$ & $31,501.25$ \\
\hline Jun-74 & $1,887.90$ & $84,048.65$ & $138,407.00$ & $25,434.00$ \\
\hline Jul-74 & 0.00 & $207,612.90$ & $172,931.00$ & $41,257.75$ \\
\hline Aug-74 & 317.30 & $129,572.48$ & $145,276.00$ & $16,933.65$ \\
\hline Sep-74 & 771.00 & $31,718.85$ & $15,516.00$ & $34,929.90$ \\
\hline Oct-74 & $10,405.40$ & $18,945.45$ & $61,159.00$ & $42,939.90$ \\
\hline Nov-74 & $1,679.10$ & $69,453.35$ & $76,100.00$ & $9,014.25$ \\
\hline Dec-74 & $6,074.00$ & $17,025.95$ & $110,571.00$ & $10,293.02$ \\
\hline Jan-75 & 0.00 & $362,830.25$ & $1,698.00$ & $25,602.00$ \\
\hline Feb-75 & $4,338.97$ & $118,484.35$ & $33,487.00$ & $1,707.00$ \\
\hline Mar-75 & $3,019.90$ & 0.00 & $31,296.00$ & $5,150.68$ \\
\hline Apr-75 & $6,141.00$ & 0.00 & $75,102.00$ & $170,103.80$ \\
\hline May-75 & $2,495.80$ & 0.00 & $113,865.00$ & $50,837.07$ \\
\hline Jun-75 & $6,560.60$ & $2,562.50$ & $138,637.00$ & $15,207.50$ \\
\hline Jul-75 & $11,515.90$ & 0.00 & $161,774.00$ & 0.00 \\
\hline Aug-75 & $21,882.47$ & 843.75 & $105,108.00$ & $17,551.13$ \\
\hline Sep-75 & 916.65 & 0.00 & $9,366.00$ & $40,367.90$ \\
\hline Oct-75 & $1,250.65$ & 0.00 & $13,450.00$ & $12,515.82$ \\
\hline Nov-75 & 0.00 & 0.00 & $177,964.00$ & $308,633.05$ \\
\hline Dec-75 & 0.00 & 0.00 & $15,948.00$ & $132,890.10$ \\
\hline Jan-76 & $8,709.50$ & $24,333.00$ & $25,803.00$ & $39,794.70$ \\
\hline Feb-76 & $13,307.90$ & 0.00 & $8,319.00$ & $13,891.25$ \\
\hline Mar-76 & $8,828.30$ & 0.00 & $22,619.00$ & $54,737.50$ \\
\hline Apr-76 & 500.00 & 0.00 & 0.00 & $241,665.50$ \\
\hline
\end{tabular}




\begin{tabular}{|c|c|c|c|c|}
\hline May-76 & $8,822.15$ & 0.00 & $9,200.00$ & $20,477.50$ \\
\hline Jun-76 & $5,700.00$ & $41,425.00$ & 0.00 & 0.00 \\
\hline Jul-76 & $16,915.55$ & $273,883.57$ & 0.00 & $27,346.90$ \\
\hline Aug-76 & $1,581.80$ & $346,481.10$ & $3,090.00$ & $1,694.00$ \\
\hline Sep-76 & 400.00 & $25,493.60$ & 0.00 & 0.00 \\
\hline Oct-76 & $3,604.20$ & 0.00 & 0.00 & 0.00 \\
\hline Nov-76 & 346.30 & $4,214.75$ & $50,650.00$ & 878.75 \\
\hline Dec-76 & 363.60 & $2,831.80$ & $1,745.00$ & $6,455.95$ \\
\hline Jan-77 & 370.30 & $25,687.50$ & $10,616.00$ & $9,439.45$ \\
\hline \multicolumn{5}{|l|}{ Feb-77 } \\
\hline \multicolumn{5}{|l|}{ Mar-77 } \\
\hline \multicolumn{5}{|l|}{ Apr-77 } \\
\hline \multicolumn{5}{|l|}{ May-77 } \\
\hline \multicolumn{5}{|l|}{ Jun-77 } \\
\hline \multicolumn{5}{|l|}{ Jul-77 } \\
\hline Aug-77 & $7,111.65$ & $15,978.30$ & $85,820.00$ & $98,266.40$ \\
\hline Sep-77 & 450.60 & 0.00 & $130,784.00$ & $69,522.85$ \\
\hline Oct-77 & 307.90 & 0.00 & $27,103.00$ & $132,552.20$ \\
\hline Nov-77 & $58,044.50$ & 0.00 & $436,334.00$ & $409,548.10$ \\
\hline Dec-77 & $14,375.70$ & 0.00 & $78,314.00$ & $1,747.20$ \\
\hline Jan-78 & $16,434.10$ & 0.00 & $73,820.00$ & $66,953.15$ \\
\hline Feb-78 & $23,952.00$ & 0.00 & $7,500.00$ & $5,240.15$ \\
\hline Mar-78 & 800.00 & $4,460.00$ & $9,000.00$ & $4,280.70$ \\
\hline Apr-78 & 600.00 & $10,022.60$ & 0.00 & $4,267.90$ \\
\hline May-78 & $2,283.30$ & $18,674.65$ & $6,000.00$ & $2,556.85$ \\
\hline Jun-78 & $1,211.00$ & $177,557.65$ & 0.00 & $3,352.85$ \\
\hline Jul-78 & $6,140.25$ & $189,009.85$ & 854.00 & $1,725.40$ \\
\hline Aug-78 & $9,015.25$ & $30,399.75$ & 0.00 & 0.00 \\
\hline Sep-78 & 0.00 & $18,022.60$ & $27,224.00$ & $5,701.10$ \\
\hline Oct-78 & 0.00 & $44,495.95$ & 0.00 & $2,400.20$ \\
\hline Nov-78 & 844.70 & $10,475.00$ & $189,570.00$ & $123,344.75$ \\
\hline Dec-78 & 0.00 & 0.00 & 0.00 & $8,653.05$ \\
\hline Jan-79 & 644.40 & $35,159.45$ & $10,800.00$ & $5,119.20$ \\
\hline Feb-79 & $6,569.05$ & $3,086.00$ & 0.00 & 9.23 \\
\hline Mar-79 & $2,417.00$ & 0.00 & $2,606.00$ & $4,324.20$ \\
\hline Apr-79 & 477.33 & $71,640.10$ & $19,078.00$ & $12,148.80$ \\
\hline May-79 & $1,248.40$ & $11,683.20$ & 0.00 & 0.00 \\
\hline Jun-79 & 0.00 & $5,950.10$ & $22,263.00$ & 857.50 \\
\hline Jul-79 & 812.00 & 0.00 & 0.00 & $5,171.10$ \\
\hline Aug-79 & $34,193.30$ & $22,672.60$ & 0.00 & 0.00 \\
\hline Sep-79 & 410.00 & $8,893.22$ & 0.00 & 0.00 \\
\hline Oct-79 & $12,791.68$ & 0.00 & 0.00 & $2,937.27$ \\
\hline Nov-79 & $19,560.25$ & $170,200.80$ & 0.00 & 206.25 \\
\hline
\end{tabular}




\begin{tabular}{|c|c|c|c|c|}
\hline Dec-79 & $3,718.40$ & $994,726.08$ & $22,200.00$ & 0.00 \\
\hline Jan-80 & $3,774.95$ & $398,093.43$ & 850.00 & 0.00 \\
\hline Feb-80 & $9,068.75$ & $807,539.45$ & 0.00 & $2,602.95$ \\
\hline Mar-80 & $1,614.90$ & $351,608.68$ & 0.00 & $1,749.20$ \\
\hline Apr-80 & 523.00 & $91,019.88$ & 0.00 & $1,890.05$ \\
\hline May-80 & 0.00 & $23,384.40$ & $16,098.00$ & 0.00 \\
\hline Jun-80 & 450.00 & $36,513.50$ & 881.00 & 884.80 \\
\hline Jul-80 & 879.15 & $11,485.30$ & 847.00 & 850.75 \\
\hline Aug-80 & $1,000.00$ & $1,105.00$ & 0.00 & $2,603.00$ \\
\hline Sep- 80 & 410.00 & $9,012.50$ & 869.00 & $1,716.70$ \\
\hline Oct- 80 & 310.50 & $6,065.60$ & 847.00 & 0.00 \\
\hline Nov-80 & 0.00 & $5,295.60$ & $24,612.00$ & $153,029.20$ \\
\hline Dec- 80 & 0.00 & 0.00 & $100,000.00$ & $64,326.35$ \\
\hline Jan-81 & 0.00 & 0.00 & 600.00 & 0.00 \\
\hline Feb-81 & 800.00 & 0.00 & 0.00 & $2,634.10$ \\
\hline Mar-81 & 606.80 & 0.00 & 0.00 & $5,215.10$ \\
\hline Apr-81 & 600.00 & $9,977.87$ & $631,315.00$ & $128,315.70$ \\
\hline May-81 & $2,200.00$ & $22,518.85$ & $24,000.00$ & $29,296.75$ \\
\hline Jun-81 & 636.50 & 0.00 & 0.00 & $89,417.30$ \\
\hline Jul-81 & $3,897.50$ & 0.00 & 0.00 & $30,613.40$ \\
\hline Aug-81 & 624.00 & 0.00 & $97,125.00$ & $60,810.30$ \\
\hline Sep-81 & 0.00 & 0.00 & $109,590.00$ & $59,799.40$ \\
\hline Oct- 81 & $1,200.00$ & $11,834.90$ & 0.00 & $6,712.85$ \\
\hline Nov-81 & $16,786.40$ & 0.00 & $2,500.00$ & $501,789.50$ \\
\hline Dec-81 & $8,865.20$ & 0.00 & $4,075.00$ & $55,193.45$ \\
\hline Jan-82 & $18,000.00$ & $173,820.97$ & $1,845.00$ & $2,649.20$ \\
\hline Feb-82 & $7,482.95$ & $85,315.42$ & 878.00 & $4,470.15$ \\
\hline Mar-82 & $5,160.90$ & 0.00 & $4,700.00$ & $56,944.05$ \\
\hline Apr-82 & 500.00 & 0.00 & $209,253.00$ & $26,773.07$ \\
\hline May-82 & $460,656.23$ & 0.00 & $95,763.00$ & $78,272.02$ \\
\hline Jun-82 & $659,556.27$ & $42,480.80$ & 0.00 & $6,225.40$ \\
\hline Jul-82 & $212,945.23$ & 0.00 & $3,428.00$ & $2,660.45$ \\
\hline \multicolumn{5}{|l|}{ Aug-82 } \\
\hline \multicolumn{5}{|l|}{ Sep-82 } \\
\hline \multicolumn{5}{|l|}{ Oct-82 } \\
\hline \multicolumn{5}{|l|}{ Nov-82 } \\
\hline \multicolumn{5}{|l|}{ Dec-82 } \\
\hline \multicolumn{5}{|l|}{ Jan-83 } \\
\hline Feb-83 & $184,182.38$ & 0.00 & $1,670.00$ & $6,924.25$ \\
\hline Mar-83 & $357,589.70$ & $1,847.40$ & $36,605.00$ & $4,954.35$ \\
\hline Apr-83 & $154,233.10$ & 0.00 & $317,860.00$ & $12,986.15$ \\
\hline May-83 & $74,066.40$ & 0.00 & $69,052.00$ & $11,704.85$ \\
\hline Jun-83 & $91,458.70$ & 0.00 & $34,333.00$ & $5,618.40$ \\
\hline
\end{tabular}




\begin{tabular}{|c|c|c|c|c|}
\hline Jul-83 & $92,490.00$ & $1,704.45$ & $79,414.00$ & $11,119.73$ \\
\hline Aug-83 & $188,894.50$ & 0.00 & $64,566.00$ & $10,050.55$ \\
\hline Sep-83 & $167,101.78$ & 0.00 & $123,477.00$ & $9,767.60$ \\
\hline Oct- 83 & $4,530.00$ & $1,963.03$ & $345,429.00$ & $101,454.70$ \\
\hline Nov-83 & $122,451.93$ & 0.00 & $214,866.00$ & $81,728.70$ \\
\hline Dec-83 & $37,709.50$ & $5,993.95$ & $161,552.00$ & $55,987.65$ \\
\hline Jan-84 & $10,485.00$ & 0.00 & $275,112.00$ & $32,708.85$ \\
\hline Feb-84 & $13,683.00$ & 0.00 & $73,097.00$ & $7,153.65$ \\
\hline Mar-84 & $17,589.00$ & $22,115.40$ & $161,097.00$ & $23,129.30$ \\
\hline Apr-84 & $9,784.93$ & $361,688.92$ & $114,982.00$ & $204,887.35$ \\
\hline May-84 & $132,032.70$ & $243,664.63$ & $92,181.00$ & $143,689.98$ \\
\hline Jun-84 & $188,574.00$ & $20,656.35$ & $87,063.00$ & $61,044.70$ \\
\hline Jul-84 & $302,832.00$ & $61,072.75$ & $83,044.00$ & $68,196.88$ \\
\hline \multicolumn{5}{|l|}{ Aug-84 } \\
\hline \multicolumn{5}{|l|}{ Sep-84 } \\
\hline \multicolumn{5}{|l|}{ Oct-84 } \\
\hline \multicolumn{5}{|l|}{ Nov-84 } \\
\hline \multicolumn{5}{|l|}{ Dec-84 } \\
\hline \multicolumn{5}{|l|}{ Jan-85 } \\
\hline Feb-85 & $59,613.20$ & 0.00 & $177,525.00$ & $23,789.30$ \\
\hline Mar-85 & $90,448.13$ & 0.00 & $335,682.00$ & $98,249.03$ \\
\hline Apr-85 & $194,290.50$ & 461.30 & $235,364.00$ & $131,520.00$ \\
\hline May-85 & $135,725.00$ & 868.65 & $305,484.00$ & $44,659.85$ \\
\hline Jun-85 & $177,386.00$ & 0.00 & $171,196.00$ & $40,915.00$ \\
\hline Jul-85 & $87,948.00$ & $3,322.80$ & $107,650.00$ & $30,471.15$ \\
\hline Aug-85 & $71,098.20$ & 198.10 & $50,425.00$ & $26,277.05$ \\
\hline Sep-85 & $685,587.40$ & 0.00 & $6,705.00$ & $15,981.60$ \\
\hline Oct-85 & $173,985.00$ & $1,909,653.70$ & $348,795.00$ & $159,926.65$ \\
\hline Nov-85 & $255,815.05$ & $121,388.35$ & $253,706.00$ & $74,069.80$ \\
\hline Dec-85 & $405,705.50$ & $1,667.00$ & $176,448.00$ & $99,035.90$ \\
\hline Jan-86 & $433,556.65$ & 615.35 & $67,996.00$ & $20,322.80$ \\
\hline Feb-86 & $197,181.55$ & 736.55 & $238,669.00$ & $29,934.45$ \\
\hline Mar-86 & $46,080.00$ & 0.00 & $331,510.00$ & $36,147.43$ \\
\hline Apr-86 & $146,397.00$ & 0.00 & $77,953.00$ & $34,860.15$ \\
\hline May-86 & $49,549.60$ & 485.50 & $381,787.00$ & $42,081.25$ \\
\hline Jun-86 & $217,282.80$ & 0.00 & $55,361.00$ & $31,877.95$ \\
\hline Jul-86 & $274,323.80$ & 164.85 & $31,433.00$ & $60,160.60$ \\
\hline Aug-86 & $149,666.60$ & 254.10 & $64,948.00$ & $28,885.25$ \\
\hline Sep-86 & $253,821.90$ & $1,355.95$ & $41,825.00$ & $30,535.50$ \\
\hline Oct-86 & $678,557.90$ & $5,005.50$ & $195,766.00$ & $35,305.20$ \\
\hline Nov-86 & $393,131.00$ & 959.70 & $224,175.00$ & $84,708.95$ \\
\hline Dec-86 & $119,610.45$ & $18,799.40$ & $362,834.00$ & $612,842.00$ \\
\hline Jan-87 & $590,355.55$ & $167,380.98$ & $28,721.00$ & $29,758.35$ \\
\hline
\end{tabular}




\begin{tabular}{|c|c|c|c|c|}
\hline Feb-87 & $342,139.00$ & $3,699.00$ & $33,650.00$ & $33,103.50$ \\
\hline Mar-87 & $421,221.85$ & $5,469.10$ & $1,750.00$ & $38,143.80$ \\
\hline Apr-87 & $464,544.20$ & $21,793.10$ & $3,627.00$ & $42,363.20$ \\
\hline May-87 & $326,724.00$ & $3,694.90$ & $26,803.00$ & $34,675.40$ \\
\hline Jun-87 & $375,232.50$ & $45,386.58$ & $11,283.00$ & $32,011.98$ \\
\hline Jul-87 & $248,930.35$ & 871.20 & $7,872.00$ & $30,469.48$ \\
\hline Aug-87 & $315,502.50$ & $104,129.25$ & $9,762.00$ & $32,765.25$ \\
\hline Sep-87 & $513,033.00$ & $196,871.55$ & $17,805.00$ & $27,504.10$ \\
\hline Oct- 87 & $888,687.70$ & $51,826.15$ & $247,620.00$ & $75,146.45$ \\
\hline Nov-87 & $194,124.60$ & $2,338.00$ & $556,685.00$ & $36,169.25$ \\
\hline Dec-87 & $15,783.00$ & $114,714.03$ & $959,013.00$ & $57,639.93$ \\
\hline Jan- 88 & $1,125.00$ & $23,868.02$ & $345,366.00$ & $58,116.10$ \\
\hline Feb-88 & $4,950.00$ & $84,316.90$ & $58,608.00$ & $39,685.00$ \\
\hline Mar-88 & $51,508.50$ & $54,698.22$ & $34,030.00$ & $59,278.55$ \\
\hline Apr-88 & $214,215.10$ & $164,898.08$ & $3,614.00$ & $47,514.00$ \\
\hline May-88 & $251,861.50$ & $41,396.27$ & $125,116.00$ & $51,934.75$ \\
\hline Jun-88 & $444,427.85$ & $109,463.20$ & $3,630.00$ & $42,275.55$ \\
\hline Jul-88 & $478,896.20$ & $100,710.63$ & $30,030.00$ & $37,151.75$ \\
\hline Aug-88 & $285,388.65$ & $3,419.95$ & $48,291.00$ & $51,037.20$ \\
\hline Sep-88 & $289,154.50$ & $114,435.07$ & $78,015.00$ & $32,292.85$ \\
\hline Oct- 88 & $846,116.55$ & $35,591.55$ & $36,362.00$ & $38,199.15$ \\
\hline Nov-88 & $487,246.80$ & $143,593.58$ & $539,663.00$ & $38,718.90$ \\
\hline Dec-88 & $133,548.00$ & $264,442.55$ & $740,048.00$ & $33,777.02$ \\
\hline Jan-89 & $13,173.00$ & $42,915.50$ & $485,865.00$ & $29,264.40$ \\
\hline Feb-89 & $122,770.50$ & $49,079.23$ & $39,593.00$ & $36,919.00$ \\
\hline Mar-89 & $169,889.40$ & $49,327.67$ & $143,946.00$ & $56,456.40$ \\
\hline Apr-89 & $16,086.00$ & $24,812.35$ & $598,185.00$ & $135,268.12$ \\
\hline May-89 & $75,954.00$ & $119,297.22$ & $14,085.00$ & $34,649.35$ \\
\hline Jun-89 & $147,739.20$ & $108,929.80$ & $81,399.00$ & $61,867.97$ \\
\hline Jul-89 & $190,473.50$ & $22,660.05$ & $4,486.00$ & $64,139.25$ \\
\hline Aug-89 & $297,603.60$ & $63,848.57$ & $10,608.00$ & $47,095.10$ \\
\hline Sep-89 & $221,104.50$ & $81,086.97$ & $1,206.00$ & $34,513.60$ \\
\hline Oct-89 & $180,741.30$ & $105,669.60$ & $2,650.00$ & $39,152.00$ \\
\hline Nov-89 & $187,760.60$ & $166,762.30$ & $371,373.00$ & $207,432.35$ \\
\hline Dec-89 & $20,400.00$ & $95,522.40$ & $398,868.00$ & $39,476.30$ \\
\hline Jan-90 & 0.00 & $19,615.45$ & $160,795.00$ & $50,338.92$ \\
\hline Feb-90 & 0.00 & $78,751.20$ & $66,809.00$ & $54,667.95$ \\
\hline Mar-90 & 0.00 & $25,945.40$ & $1,650.00$ & $72,894.15$ \\
\hline Apr-90 & $4,740.00$ & $97,700.15$ & $8,495.00$ & $64,903.55$ \\
\hline May-90 & $43,716.00$ & $247,207.68$ & $3,563.00$ & $77,838.10$ \\
\hline Jun-90 & $261,723.00$ & $3,311.60$ & $9,319.00$ & $76,428.95$ \\
\hline Jul-90 & $116,354.30$ & 637.88 & 890.00 & $44,439.20$ \\
\hline Aug-90 & $267,780.00$ & $25,868.25$ & $6,299.00$ & $89,145.30$ \\
\hline
\end{tabular}




\begin{tabular}{|c|c|c|c|c|}
\hline Sep-90 & $138,244.70$ & $189,287.20$ & $1,812.00$ & $65,507.00$ \\
\hline Oct-90 & $332,921.10$ & $160,733.87$ & $18,208.00$ & $78,588.60$ \\
\hline Nov-90 & $559,305.15$ & $236,744.33$ & $41,058.00$ & $61,481.35$ \\
\hline Dec-90 & $93,817.50$ & 349.40 & $927,224.00$ & $65,420.55$ \\
\hline Jan-91 & $5,616.00$ & $52,688.00$ & $88,902.00$ & $49,506.38$ \\
\hline Feb-91 & $7,494.00$ & $1,585.85$ & $273,832.00$ & $109,971.53$ \\
\hline Mar-91 & $47,700.00$ & $2,397.95$ & $96,739.00$ & $135,059.03$ \\
\hline Apr-91 & $13,270.50$ & $1,614.45$ & $255,776.00$ & $164,138.85$ \\
\hline May-91 & $95,480.00$ & $2,517.80$ & $128,288.00$ & $450,312.75$ \\
\hline Jun-91 & $453,760.00$ & $348,902.88$ & $2,747.00$ & $55,687.50$ \\
\hline Jul-91 & $94,815.00$ & $98,993.85$ & $63,330.00$ & $55,924.47$ \\
\hline Aug-91 & $634,382.20$ & $306,059.88$ & $38,982.00$ & $71,940.85$ \\
\hline Sep-91 & $204,453.00$ & $1,636.45$ & $9,211.00$ & $61,379.47$ \\
\hline Oct-91 & $177,498.60$ & $2,091.30$ & $6,893.00$ & $60,090.80$ \\
\hline Nov-91 & $190,813.80$ & $2,077.75$ & $489,169.00$ & $185,428.65$ \\
\hline Dec-91 & $133,944.50$ & 617.35 & $384,140.00$ & $44,415.00$ \\
\hline Jan-92 & $120,310.40$ & 827.70 & $93,425.00$ & $69,134.80$ \\
\hline Feb-92 & $128,121.00$ & 489.05 & $73,169.00$ & $46,457.10$ \\
\hline Mar-92 & $128,306.50$ & 750.05 & $271,149.00$ & $89,860.68$ \\
\hline Apr-92 & $273,315.00$ & $240,584.25$ & $139,418.00$ & $164,992.70$ \\
\hline May-92 & $313,365.00$ & $238,189.73$ & $131,074.00$ & $178,449.40$ \\
\hline Jun-92 & $161,854.00$ & 844.82 & $438,318.00$ & $97,404.35$ \\
\hline Jul-92 & $148,197.70$ & 0.00 & $234,942.00$ & $166,335.60$ \\
\hline Aug-92 & $143,322.00$ & $145,356.60$ & $145,979.00$ & $67,395.80$ \\
\hline Sep-92 & $191,897.00$ & 900.05 & $90,915.00$ & $71,355.15$ \\
\hline Oct-92 & $278,040.90$ & 232.20 & $19,674.00$ & $68,656.35$ \\
\hline Nov-92 & $680,177.63$ & $11,863.05$ & $48,455.00$ & $71,187.90$ \\
\hline Dec-92 & $270,530.15$ & 380.40 & $168,328.00$ & $230,200.75$ \\
\hline Jan-93 & $273,875.30$ & $1,618.40$ & $204,517.00$ & $71,746.92$ \\
\hline Feb-93 & $189,815.65$ & $1,645.60$ & $274,921.00$ & $115,916.35$ \\
\hline Mar-93 & $71,071.50$ & $1,036.00$ & $300,014.00$ & $92,286.90$ \\
\hline Apr-93 & $73,757.85$ & 848.50 & $377,685.00$ & $72,471.75$ \\
\hline May-93 & $285,020.40$ & $374,528.10$ & $858,679.00$ & $173,674.33$ \\
\hline Jun-93 & $188,712.77$ & $3,447.85$ & $422,798.00$ & $100,566.10$ \\
\hline Jul-93 & $84,470.60$ & $1,806.65$ & $224,124.00$ & $62,751.00$ \\
\hline Aug-93 & $220,997.20$ & $10,110.15$ & $129,343.00$ & $53,373.00$ \\
\hline Sep-93 & $40,623.00$ & $1,331.00$ & $86,628.00$ & $54,585.65$ \\
\hline Oct-93 & $96,540.00$ & $1,752.25$ & $133,843.00$ & $61,629.75$ \\
\hline Nov-93 & $289,878.00$ & $2,885.75$ & $76,779.00$ & $47,728.85$ \\
\hline Dec-93 & $257,745.00$ & $66,204.13$ & $497,125.00$ & $73,100.85$ \\
\hline Jan-94 & $63,888.00$ & $57,727.27$ & $37,878.00$ & $47,411.30$ \\
\hline Feb-94 & $106,005.00$ & $1,945.85$ & $224,802.00$ & $64,672.95$ \\
\hline Mar-94 & $83,284.00$ & $1,942.05$ & $216,590.00$ & $59,290.95$ \\
\hline
\end{tabular}




\begin{tabular}{|c|c|c|c|c|}
\hline Apr-94 & $15,747.00$ & $125,121.53$ & $292,345.00$ & $49,925.35$ \\
\hline May-94 & $55,410.00$ & $1,022,275.45$ & $228,580.00$ & $56,609.60$ \\
\hline Jun-94 & $207,507.00$ & $298,151.93$ & $98,022.00$ & $65,563.80$ \\
\hline Jul-94 & $43,857.00$ & $182,252.77$ & $50,948.00$ & $58,163.90$ \\
\hline Aug-94 & $62,349.00$ & $576,368.20$ & $101,476.00$ & $57,266.95$ \\
\hline Sep-94 & $10,125.00$ & $2,813.90$ & $226,467.00$ & $47,678.05$ \\
\hline Oct-94 & $26,592.00$ & $64,115.20$ & $112,239.00$ & $44,143.40$ \\
\hline Nov-94 & $25,737.00$ & $20,463.10$ & $309,909.00$ & $300,312.27$ \\
\hline Dec-94 & $40,506.00$ & $128,805.57$ & $365,157.00$ & $85,704.35$ \\
\hline Jan-95 & $35,118.00$ & $179,740.70$ & $6,621.00$ & $31,202.80$ \\
\hline Feb-95 & $46,684.30$ & $2,856.00$ & $15,919.00$ & $44,765.20$ \\
\hline Mar-95 & $27,636.00$ & $2,108.25$ & $123,943.00$ & $65,230.60$ \\
\hline Apr-95 & $4,986.00$ & $22,366.80$ & $281,830.00$ & $43,157.00$ \\
\hline May-95 & $22,184.30$ & $24,468.50$ & $204,971.00$ & $49,828.00$ \\
\hline Jun-95 & $49,196.50$ & $137,404.30$ & $79,836.00$ & $253,656.63$ \\
\hline Jul-95 & 0.00 & $2,749.98$ & $84,212.00$ & $291,572.30$ \\
\hline Aug-95 & $3,600.00$ & $3,921.00$ & $53,507.00$ & $44,850.70$ \\
\hline Sep-95 & $59,589.00$ & $11,351.55$ & $61,854.00$ & $36,098.30$ \\
\hline Oct-95 & $205,669.50$ & $5,652.00$ & $13,261.00$ & $244,618.50$ \\
\hline Nov-95 & $130,863.80$ & $28,858.40$ & $224,037.00$ & $46,820.13$ \\
\hline Dec-95 & $55,140.00$ & $85,730.80$ & $58,571.00$ & $42,127.75$ \\
\hline Jan-96 & $88,128.20$ & $32,675.23$ & $19,889.00$ & $58,477.55$ \\
\hline Feb-96 & $179,979.10$ & $6,673.15$ & $115,244.00$ & $76,721.75$ \\
\hline Mar-96 & $149,403.00$ & $8,008.20$ & $17,372.00$ & $57,250.90$ \\
\hline Apr-96 & $137,732.30$ & $36,303.23$ & $70,171.00$ & $56,238.75$ \\
\hline May-96 & $138,771.00$ & $304,043.18$ & $123,066.00$ & $66,894.90$ \\
\hline Jun-96 & $133,998.00$ & $96,978.43$ & $181,541.00$ & $62,116.70$ \\
\hline Jul-96 & $34,402.00$ & $72,280.38$ & $22,573.00$ & $56,540.10$ \\
\hline Aug-96 & $100,982.00$ & $101,314.52$ & $15,132.00$ & $57,564.85$ \\
\hline Sep-96 & $25,954.50$ & $34,728.65$ & $248,374.00$ & $38,865.85$ \\
\hline Oct-96 & $80,223.60$ & $38,853.70$ & $47,562.00$ & $235,678.85$ \\
\hline Nov-96 & $97,574.70$ & $10,353.35$ & $99,833.00$ & $86,673.35$ \\
\hline Dec-96 & $155,232.55$ & $45,018.80$ & $290,850.00$ & $30,647.15$ \\
\hline Jan-97 & $123,383.20$ & $161,004.30$ & $7,788.00$ & $69,762.35$ \\
\hline Feb-97 & $199,219.70$ & $90,696.00$ & $7,148.00$ & $41,515.45$ \\
\hline Mar-97 & $216,923.00$ & $46,972.95$ & $63,253.00$ & $49,048.90$ \\
\hline Apr-97 & $251,432.00$ & $44,003.20$ & $697,509.00$ & $47,140.00$ \\
\hline May-97 & $502,977.85$ & $30,159.32$ & $155,454.00$ & $93,267.90$ \\
\hline Jun-97 & $547,987.40$ & $30,686.30$ & $13,417.00$ & $57,735.30$ \\
\hline Jul-97 & $452,420.00$ & $21,096.45$ & $3,751.00$ & $38,411.25$ \\
\hline \multicolumn{5}{|l|}{ Aug-97 } \\
\hline \multicolumn{5}{|l|}{ Sep-97 } \\
\hline Oct-97 & & & & \\
\hline
\end{tabular}




\begin{tabular}{|c|c|c|c|c|}
\hline \multicolumn{5}{|l|}{ Nov-97 } \\
\hline \multicolumn{5}{|l|}{ Dec-97 } \\
\hline \multicolumn{5}{|l|}{ Jan-98 } \\
\hline Feb-98 & $51,042.00$ & $1,835.25$ & $12,892.00$ & $23,016.12$ \\
\hline Mar-98 & $216,798.00$ & $15,189.48$ & $142,377.00$ & $29,509.90$ \\
\hline Apr-98 & $6,888.00$ & $33,180.12$ & $233,110.00$ & $237,245.33$ \\
\hline May-98 & $402,185.30$ & $42,003.20$ & $207,678.00$ & $37,903.92$ \\
\hline Jun-98 & $179,351.90$ & $8,420.30$ & $13,471.00$ & $57,640.02$ \\
\hline Jul-98 & $154,964.40$ & $3,751.15$ & $22,442.00$ & $67,041.35$ \\
\hline Aug-98 & $255,661.00$ & $78,688.35$ & $373,486.00$ & $47,891.60$ \\
\hline Sep-98 & $329,362.90$ & 528.45 & $365,242.00$ & $49,625.30$ \\
\hline Oct-98 & $409,924.90$ & $706,765.30$ & $3,220.00$ & $40,335.27$ \\
\hline Nov-98 & $300,261.20$ & $899,359.70$ & $780,586.00$ & $25,894.67$ \\
\hline Dec-98 & $199,486.90$ & $71,153.55$ & $426,599.00$ & $34,842.73$ \\
\hline Jan-99 & $239,540.70$ & $5,278.60$ & $4,849.00$ & $34,341.58$ \\
\hline Feb-99 & $202,214.50$ & 0.00 & $226,775.00$ & $50,755.60$ \\
\hline Mar-99 & $244,456.00$ & $300,000.00$ & $516,603.00$ & $162,951.07$ \\
\hline Apr-99 & $135,708.00$ & $1,049.40$ & $38,544.00$ & $126,532.97$ \\
\hline May-99 & $116,241.00$ & 836.65 & $143,258.00$ & $85,931.45$ \\
\hline Jun-99 & $305,985.40$ & 0.00 & $258,471.00$ & $114,059.22$ \\
\hline Jul-99 & $193,570.50$ & 541.75 & $131,634.00$ & $209,086.80$ \\
\hline Aug-99 & $281,760.00$ & 0.00 & $12,393.00$ & $95,752.83$ \\
\hline Sep-99 & $230,132.50$ & $15,454.98$ & $20,595.00$ & $57,793.25$ \\
\hline Oct-99 & $202,075.00$ & 669.20 & $87,109.00$ & $117,560.53$ \\
\hline Nov-99 & $343,926.55$ & 0.00 & $250,785.00$ & $49,087.97$ \\
\hline Dec-99 & $338,751.00$ & 0.00 & $473,692.00$ & $38,129.68$ \\
\hline Jan-00 & $295,651.00$ & 887.00 & $162,391.00$ & $49,528.42$ \\
\hline Feb-00 & $414,494.00$ & 0.00 & $92,656.00$ & $49,365.63$ \\
\hline Mar-00 & $294,717.00$ & 0.00 & $287,522.00$ & $101,260.07$ \\
\hline Apr-00 & $202,891.60$ & $1,418.90$ & $888,665.00$ & $46,190.45$ \\
\hline May-00 & $113,160.00$ & $35,782.25$ & $1,904.00$ & $57,833.35$ \\
\hline Jun-00 & $158,005.00$ & $78,574.32$ & $13,019.00$ & $51,952.15$ \\
\hline Jul-00 & $217,719.70$ & $42,656.53$ & $14,613.00$ & $75,711.50$ \\
\hline \multicolumn{5}{|l|}{ Aug-00 } \\
\hline \multicolumn{5}{|l|}{ Sep-00 } \\
\hline \multicolumn{5}{|l|}{ Oct-00 } \\
\hline \multicolumn{5}{|l|}{ Nov-00 } \\
\hline \multicolumn{5}{|l|}{ Dec-00 } \\
\hline \multicolumn{5}{|l|}{ Jan-01 } \\
\hline Feb-01 & $1,000,918.00$ & $76,062.00$ & $10,842.00$ & $15,740.85$ \\
\hline Mar-01 & $295,339.00$ & $15,252.60$ & $78,514.00$ & $101,112.77$ \\
\hline Apr-01 & $438,613.65$ & $33,020.80$ & $898,806.00$ & $79,438.60$ \\
\hline May-01 & $476,311.20$ & $12,616.00$ & $31,606.00$ & $55,779.05$ \\
\hline
\end{tabular}




\begin{tabular}{|c|c|c|c|c|}
\hline Jun-01 & $240,974.00$ & 439.00 & $23,500.00$ & $59,903.60$ \\
\hline Jul-01 & $297,155.00$ & 585.70 & $50,850.00$ & $181,757.35$ \\
\hline Aug-01 & $674,192.50$ & 0.00 & $546,573.00$ & $215,119.93$ \\
\hline Sep-01 & $151,970.00$ & 511.50 & $315,060.00$ & $74,588.87$ \\
\hline Oct-01 & $107,983.50$ & 0.00 & $485,866.00$ & $146,374.82$ \\
\hline Nov-01 & $127,254.00$ & 572.40 & $553,705.00$ & $99,400.80$ \\
\hline Dec-01 & $172,701.00$ & 0.00 & $457,281.00$ & $134,440.05$ \\
\hline Jan-02 & $97,540.00$ & $1,856.88$ & $75,246.00$ & $55,962.98$ \\
\hline Feb-02 & $186,039.50$ & $12,400.00$ & $146,978.00$ & $73,961.33$ \\
\hline Mar-02 & $273,878.95$ & $2,669.50$ & $48,937.00$ & $54,078.15$ \\
\hline Apr-02 & $153,588.45$ & $3,594.70$ & $80,264.00$ & $184,334.42$ \\
\hline May-02 & $141,577.20$ & 0.00 & $92,276.00$ & $86,812.15$ \\
\hline Jun-02 & $101,424.00$ & 0.00 & $100,298.00$ & $61,564.60$ \\
\hline Jul-02 & $77,450.15$ & 0.00 & $6,828.00$ & $38,648.30$ \\
\hline Aug-02 & $95,793.00$ & 0.00 & $192,896.00$ & $42,243.35$ \\
\hline Sep-02 & $26,519.00$ & 0.00 & $43,261.00$ & $84,601.35$ \\
\hline Oct- 02 & $153,122.00$ & $18,441.85$ & $204,600.00$ & $39,448.90$ \\
\hline Nov-02 & $64,903.75$ & $13,446.30$ & $666,366.00$ & $36,393.90$ \\
\hline Dec-02 & $52,639.00$ & $11,822.32$ & $461,310.00$ & $134,852.70$ \\
\hline Jan-03 & $16,509.00$ & $45,754.70$ & $87,529.00$ & $53,628.35$ \\
\hline
\end{tabular}




\section{Table A9. Calculation of Withdrawal Revenue}

\begin{tabular}{|c|c|c|c|c|c|c|c|}
\hline $\begin{array}{r}\text { Fiscal } \\
\text { Year }\end{array}$ & Revenue & $\begin{array}{r}\text { Change in } \\
\text { VOC } \\
\text { Interest Due }\end{array}$ & $\begin{array}{r}\text { VOC Inter- } \\
\text { est }\end{array}$ & $\begin{array}{r}\text { Holland } \\
\text { Interest }\end{array}$ & $\begin{array}{l}\text { "Withdrawal" } \\
\text { Revenue }\end{array}$ & $\begin{array}{r}\text { Metal Outflow } \\
\text { through } \\
\text { Specie Kamer }\end{array}$ & Ratio \\
\hline 1666 & 39,934 & $-4,025$ & $-11,750$ & -8673 & 15,487 & $2,049,670$ & $0.76 \%$ \\
\hline 1667 & 57,861 & $-2,361$ & $-26,667$ & -8673 & 20,141 & $2,560,011$ & $0.79 \%$ \\
\hline 1668 & 74,949 & $-10,022$ & $-35,933$ & -8673 & 20,340 & $2,431,159$ & $0.84 \%$ \\
\hline 1669 & 42,313 & 18,333 & $-46,283$ & -8673 & 5,690 & 610,589 & $0.93 \%$ \\
\hline 1670 & 20,861 & 0 & 0 & -8673 & 12,189 & $1,555,197$ & $0.78 \%$ \\
\hline 1671 & 56,491 & 0 & $-6,362$ & -8673 & 41,633 & $3,344,676$ & $1.24 \%$ \\
\hline 1672 & 88,594 & 0 & -800 & -8673 & 79,119 & $3,617,700$ & $2.19 \%$ \\
\hline \multicolumn{8}{|l|}{1673} \\
\hline 1674 & 28,794 & 0 & -942 & -8673 & 19,177 & $1,189,420$ & $1.61 \%$ \\
\hline 1675 & 49,354 & 0 & $-8,489$ & -8673 & 32,193 & $1,696,559$ & $1.90 \%$ \\
\hline 1676 & 57,506 & $-15,507$ & $-32,678$ & -8673 & 647 & 482,826 & $0.13 \%$ \\
\hline 1677 & 74,023 & $-35,506$ & $-5,509$ & -8673 & 24,336 & & \\
\hline 1678 & 74,636 & 37,680 & $-99,455$ & -8673 & 4,186 & 417,590 & $1.00 \%$ \\
\hline 1679 & 78,004 & 0 & $-64,000$ & -8673 & 5,332 & 92,651 & $5.75 \%$ \\
\hline 1680 & 63,534 & 5,000 & $-56,111$ & -8673 & 3,750 & 374,407 & $1.00 \%$ \\
\hline 1681 & 79,889 & 3,333 & $-41,789$ & -8673 & 32,760 & $1,842,897$ & $1.78 \%$ \\
\hline 1682 & 56,497 & 1,667 & $-31,745$ & -8260 & 18,159 & & \\
\hline 1683 & 42,598 & $-1,866$ & $-18,689$ & -8260 & 13,782 & $2,068,942$ & $0.67 \%$ \\
\hline 1684 & 64,987 & 5,199 & 0 & -8260 & 61,926 & & \\
\hline
\end{tabular}

Source: van Dillen 1925: 701-807, and authors' calculation. 
Table A10. The VOC-AWB Credit Relationship

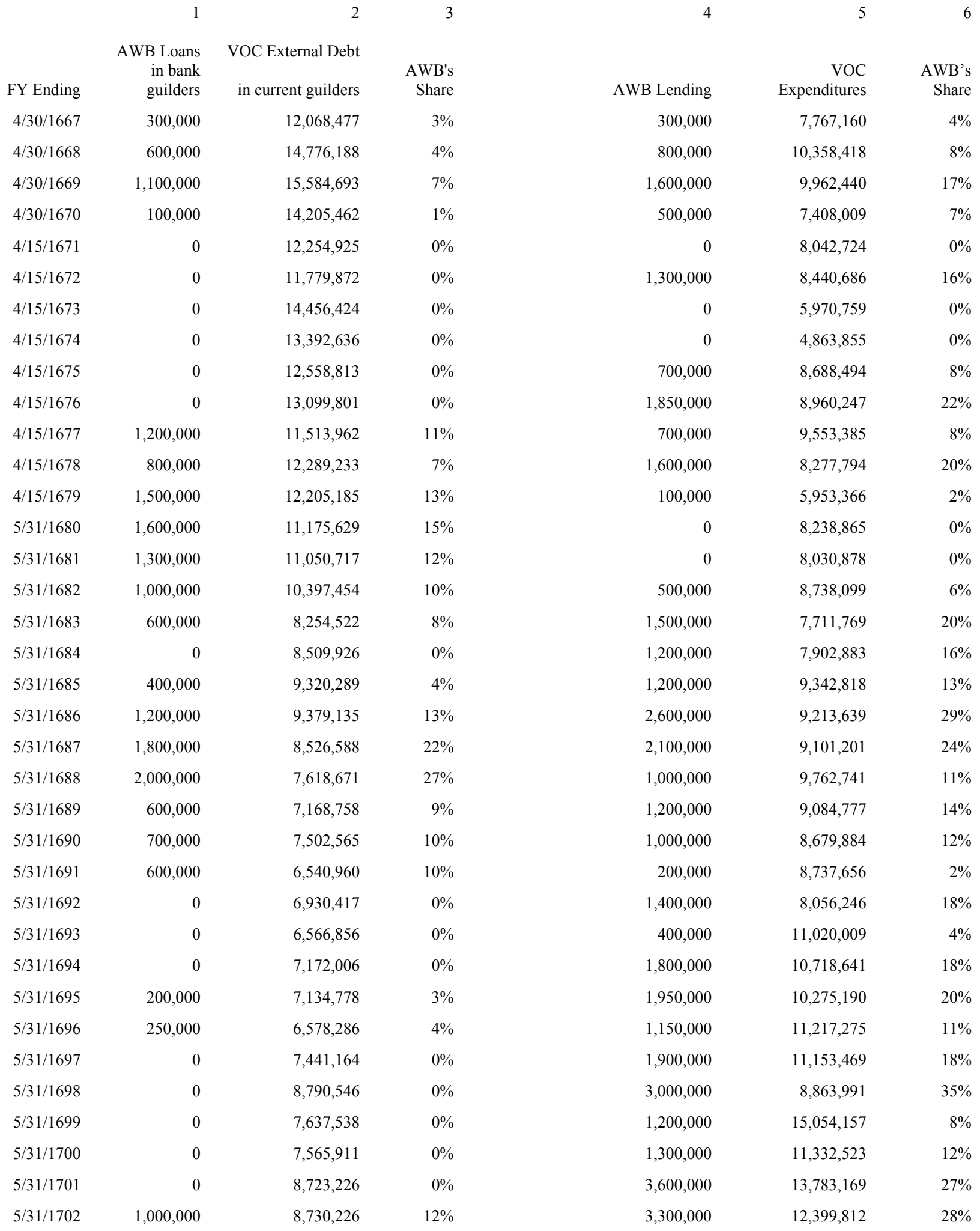

Source: VOC data from de Korte (1984: 1A-1C). 


\section{Appendix B. Theoretical illustrations}

This appendix offers a formal examination of the efficiency gains stemming from changes in the AWB's credit policies following the 1683 reform. The model environment considered builds in a natural financial intermediary and payments provider role for the Bank of Amsterdam, i.e., the bank is endowed with advantages in these capacities. The model then traces through the consequences of the bank's transition to a fiat standard.

Time is discrete and infinite in the model environment. Time is indexed by $t$, and each period (which can be thought of as a "year" for convenience) is subdivided into 3 stages $\{0,1,2\}$, referred to as winter, spring/summer, and autumn. There are 2 classes of agents, domestic and foreign. Foreign agents have measure 1 and domestic agents have measure $1 / 2 .{ }^{64}$ Agents are ex ante identical within a class. Domestic agents coordinate their production and consumption decisions and function as a single agent. In addition to private agents, there is an exchange bank whose activities are described below. Economic activity takes place in 2 locations, the domestic economy (“Amsterdam") and elsewhere ("abroad").

\section{Synopsis of the model}

The model incorporates a stylized cycle of trade. Foreign agents (natural lenders) earn silver abroad in the winter and bring it to Amsterdam in spring, in search of trading opportunities. Silver is exchanged with the coalition of domestic agents (a natural borrower) in return for bank money that can be used to purchase goods in Amsterdam. Domestic agents use the silver they obtain for consumption abroad, while engaged in productive activities (overseas expeditions) that do not return goods until the autumn of the same year.

At the beginning of autumn, some foreign agents experience a liquidity (i.e., preference) shock, meaning they must depart Amsterdam in order to consume. Also in autumn, goods arrive in Amsterdam from summer productive activities undertaken by domestic agents. Foreign agents not experiencing a liquidity shock may either purchase these goods with bank money, or may choose to liquidate their bank balances for silver, which can then be used to purchase consumption goods abroad. Table 1 summarizes the timing of actions in the model.

\footnotetext{
${ }^{64}$ The labels "domestic" and "foreign" are more handy than accurate. "Long-term participants in the Amsterdam markets" and "opportunistic participants" might be more exact.
} 


\section{Table 1: Timing of actions in the model}

\begin{tabular}{|c|c|c|c|}
\hline Time of year & \multicolumn{2}{|c|}{$\begin{array}{c}\text { Foreign agents } \\
\text { (overlapping generations) }\end{array}$} & $\begin{array}{l}\text { Domestic agents } \\
\text { (infinitely lived) }\end{array}$ \\
\hline Winter (stage 0) & \multicolumn{2}{|c|}{$\begin{array}{l}\text { Young foreign agents trade production goods } \\
\text { abroad for silver }\end{array}$} & \\
\hline Spring (stage 1a) & \multicolumn{2}{|c|}{$\begin{array}{l}\text { Young arrive in Amsterdam; trade silver for } \\
\text { bank money; old (liquidity constrained) trade } \\
\text { money for silver and depart Amsterdam }\end{array}$} & $\begin{array}{l}\text { Trade money for silver } \\
\text { in Amsterdam }\end{array}$ \\
\hline $\begin{array}{l}\text { Summer (stage } \\
\text { 1b) }\end{array}$ & \multicolumn{2}{|c|}{$\begin{array}{l}\text { Old, liquidity-constrained agents purchase con- } \\
\text { sumption goods abroad }\end{array}$} & $\begin{array}{l}\text { Use silver to purchase } \\
\text { consumption abroad; } \\
\text { Begin production }\end{array}$ \\
\hline \multirow[t]{2}{*}{$\begin{array}{l}\text { Early autumn } \\
\text { (stage 2a) }\end{array}$} & \multicolumn{2}{|c|}{ Liquidity shock revealed for young agents } & $\begin{array}{l}\text { Goods arrive in Amster- } \\
\text { dam from summer pro- } \\
\text { duction }\end{array}$ \\
\hline & If liquidity shock & If no shock & \\
\hline $\begin{array}{l}\text { Autumn (stage } \\
\text { 2b) }\end{array}$ & $\begin{array}{l}\text { No action; wait to } \\
\text { trade money for sil- } \\
\text { ver next period }\end{array}$ & $\begin{array}{l}\text { Use money to purchase } \\
\text { goods from domestic } \\
\text { agents \& consume }\end{array}$ & $\begin{array}{l}\text { Sell goods to domestic } \\
\text { agents for money }\end{array}$ \\
\hline
\end{tabular}

\section{Commodities and feasible trades}

There are 3 commodities: a nondurable general consumption good, a nondurable special consumption good, and a durable good, silver, which is used for only for trade. Silver can be stored at negligible cost.

All trading outside Amsterdam is of silver for the other goods, and always at the world price of $\phi$ units of silver per good, normalized to $\phi=1$ for both goods. All trading within Amsterdam is of goods for money (bank balances, described below). For expositional clarity, domestic agents may not purchase silver by issuing IOUs to foreign agents. ${ }^{65}$ Likewise, foreign agents may not directly purchase special goods from domestic agents with silver, but must use money to make their purchases. Finally, domestic agents must sell their special good production in their "home market," Amsterdam.

\footnotetext{
${ }^{65}$ This constraint could be partially relaxed without qualitatively changing the model results. What matters is that foreign agents are less willing to accept domestic agents' debt than is the bank.
} 


\section{Preferences, endowments, and technologies}

Each generation of foreign agents lives for 2 years. A generation- $t$ foreign agent is born abroad in stage 0 of the year $t$ and can produce $x_{0 t}$ units of the general good for sale on the world market. He (typically) journeys to Amsterdam in stage 1, although the agent always has the option of remaining abroad and trading exclusively in the world market. At the beginning of stage 2, a foreign agent experiences a shock that determines his preferences for general good versus special good consumption. The utility of a generation- $t$ foreign agent $i$ is

$$
U_{t}=-x_{0 t}^{i}+\lambda_{2 t}^{i} \beta u\left(c_{1, t+1}^{i}\right)+\left(1-\lambda_{2 t}^{i}\right) u\left(f_{2 t}^{i}\right)
$$

where $\beta$ is an annual discount factor, $c_{1, t+1}^{i}$ represents $i$ 's consumption of the general good (which takes place in the summer of year $t+1), f_{2 t}^{i}$ represents his consumption of the special good (which typically takes place in the autumn of year $t),{ }^{66} \lambda_{2 t}^{i}$ is a preference shock, and $u$ is a concave utility function. To allow for analytic results, we take $u(c)=c^{(1-\rho)} /(1-\rho)$ where $\rho \in(0,1)$. The probability distribution for $\lambda_{2 t}$ is

$$
\lambda_{2 t}=\left\{\begin{array}{l}
1 \text { with probability } 1 / 2, \\
0 \text { with probability } 1 / 2 .
\end{array}\right.
$$

An agent who receives a preference shock $\lambda_{2 t}=1$ is said to be "liquidity constrained," in the sense that the agent only wants to consume the general good, which is only available abroad for silver. The remaining (called "unconstrained") foreign agents want to consume the special good, either abroad or in Amsterdam, depending on market conditions. An agent's type (constrained or not) is private information.

Domestic agents are infinitely lived and have objective

$$
V=\sum_{t=0}^{\infty} \beta^{t}\left(d_{1 t}-a x_{1 t}\right)
$$

where $d_{1 t}$ is the agent's summer (stage 1) consumption of the general good abroad, $x_{1 t}$ is the summer production of the special good undertaken by the agent, and $a \in(0, \beta)$. There is no discounting from spring to autumn. Productive effort $x_{1 t}$ yields $y_{2 t}=x_{1 t}$ special goods which are brought to Amsterdam. Domestic agents cannot earn silver abroad, so silver for their general

\footnotetext{
${ }^{66}$ This is a slight abuse of notation: the special good may also be purchased on the world market and consumed in the spring of the next year, although this does not occur in the equilibria we consider.
} 
good consumption must be obtained through trade in Amsterdam with foreign agents. Foreign agents have an incentive to trade with domestic agents in the Amsterdam market, since domestic agents can produce the special good at a cost below the world price of one. ${ }^{67}$

Silver can be held by domestic agents, foreign agents young or old, or the exchange bank (described below). Let $S_{1 t}^{y}\left(S_{1 t}^{o}\right)$ be the per-capita, non-negative amount of silver held by old foreign agents at the end of stage 1a money market trading, and let $S_{1 t}^{d}\left(S_{2 t}^{d}\right)$ be domestic agents' stage 1a (stage 2) per-capita silver holdings (again nonnegative). The amount of silver (per domestic resident) held at the exchange bank after stage 1(2) trading is $S_{1 t}^{b}\left(S_{2 t}^{b}\right)$.

\section{Efficient steady-state allocations}

As a benchmark, we first consider efficient steady-state allocations. The planner maximizes the population-weighted discounted utility of all agents, i.e.,

$$
W=V / 2+\sum_{t=0}^{\infty} \beta^{t} E\left(U_{t}\right)
$$

over allocations $\left(x_{0 t}, x_{1 t}, d_{1 t}, c_{1 t}, f_{2 t}, S_{1 t}^{y}, S_{1 t}^{o}, S_{1 t}^{d}, S_{2 t}^{d}, S_{1 t}^{b}\right)$. Feasibility constraints are

$$
\begin{gathered}
2 x_{0 t}+S_{2, t-1}^{d}+S_{1, t-1}^{b}+ \\
2 S_{1, t-1}^{y} \geq 2 S_{1, t}^{y}+S_{1, t}^{o}+S_{1 t}^{d}+S_{1 t}^{b}, \\
S_{1 t}^{o} \geq c_{1 t}, \\
S_{1, t}^{d} \geq d_{1, t} \\
x_{1 t} \geq f_{2 t} .
\end{gathered}
$$

Constraint (8) says that the total silver available to the Amsterdam economy in stage 1a consists of silver imported by young foreigners plus any silver stored by domestic agents, the bank, and old foreigners. Constraint (9) says that the general good consumption of foreigners is limited by the amount of silver they have available. A similar constraint (10) applies to consumption by domestic agents. Constraint (11) is the resource constraint on special good consumption by foreigners. The truth-telling condition for the planner's problem is

$$
u\left(f_{2 t}\right) \geq \beta u\left(c_{1, t+1}\right),
$$

\footnotetext{
${ }^{67}$ I.e., the law of one price does not hold for special goods. Sufficient frictions operate in the background to allow this situation to persist.
} 
i.e., an unconstrained foreign agent must do at least as well by consuming domestically as he could by reporting himself as a constrained agent, accepting a silver payment, and then using the silver to purchase the special good abroad the following year. Participation constraints for foreign and domestic agents are

$$
E U, V \geq 0 \text {. }
$$

The set of planner's allocations (superscript $p$ ) is described as

$$
\begin{gathered}
u^{\prime}\left(c_{1}^{p}\right)=1 \text {, i.e., } c_{1}^{p}=S_{1}^{o, p}=1 \\
u^{\prime}\left(f_{2}^{p}\right)=a \text {, i.e., } f_{2}^{p}=x_{1}=a^{-(1 / \rho)} \\
d_{1}^{p}=S_{1}^{d, p} \in\left[a f_{2}^{p}, \bar{d}\right] \text {, where } \bar{d}=u\left(c_{1}^{p}\right)+u\left(f_{2}^{p}\right)-c_{1}^{p} \\
2 x_{0}=c_{1}^{p}+d_{1}^{p} \\
S_{2}^{d, p}=S_{1}^{b, p}=S_{1}^{y, p}=0
\end{gathered}
$$

Conditions (14) and (15) are standard optimality conditions. Note that truth-telling condition (12) does not bind in the planner's allocation. Condition (16) says that domestic agents' consumption is indeterminate between the bounds imposed by individual rationality for both classes of agents. Condition (17) says that silver imports by young foreigners must be sufficient to cover general good consumption by domestic agents and old foreigners. Silver carries an opportunity cost and has no liquidity value over the winter, so the planner sets inter-period holdings of silver by domestic agents, the bank, and foreigners equal to zero (condition (18)).

\section{The exchange bank}

Money takes the form of balances at an exchange bank. Initially we assume the bank does not engage in lending. More specifically, the exchange bank credits any deposits of silver into the exchange bank at a fixed number of units of silver $\bar{\theta}$ per florin of bank money, normalized to $\bar{\theta}=1$. Withdrawals from the bank occur at a mandated price $\underline{\theta}<1$.

In the decentralized economy, money can be traded for silver in stage 1a. The market value of money in terms of silver is $\theta$ units of silver per unit money ("florin"). ${ }^{68}$ Absence of arbitrage

\footnotetext{
${ }^{68}$ I.e., the price of bank money is proportional to one plus the agio. As explained above, the actual agio expressed the price of bank money relative to current money, whose metallic value could vary over time. While a model of current money valuation could be incorporated in to the model, we abstract from this complication to keep notation manageable.
} 
requires that the market price of bank money be in the interval $[\underline{\theta}, 1]$. As long as the market price of money is in this interval, there is (weakly) no incentive for agents to deposit or withdraw silver from the bank: hence, for steady states (i.e., for constant $\theta$ ) we exclude the possibility of deposits or withdrawals.

However, anyone with funds at the exchange bank has the option of withdrawing funds from the bank at any time. Suppose that at a given moment the bank has liabilities (accounts) of $M$ florins per domestic resident and holds $S^{b}$ units of silver ("coins") in its vault. Strictly speaking, the depositors' right of withdrawal means that the exchange bank faces a liquidity constraint on its metal-to-deposit ratio $S^{b} / M^{69}$

$$
S^{b} / M \geq \underline{\theta} .
$$

Taken at face value, this would require that the bank maintain a metal-to-deposit ratio of around 98 percent. As we have seen above, in practice the AWB was generally able operate with a smaller ratio. Hence (19) is modified to

$$
S^{b} / M \geq \delta \underline{\theta},
$$

for some "comfort factor" $\delta<1$.

The special consumption good is traded in Amsterdam in stage 2 at money price $p_{t}$. Since unconstrained foreigners can choose where to consume the special good in stage 2 , the silverequivalent price of special goods in Amsterdam $\sigma_{t} \equiv\left(\theta_{t} p_{t}\right)$ (i.e., the terms of trade for domestic agents) can be no greater the silver price of goods abroad (one).

\section{Steady-state monetary equilibria}

In the decentralized economy, young foreign agents wishing to purchase goods in Amsterdam must first use their silver earnings to purchase money holdings $M_{1 t}^{y}$. Foreign agents maximize the expectation of utility (4) over $x_{0}, c_{1}, f_{2}, M_{1}^{y}$, and $S_{1}^{y}$, taking prices as given, subject to budget constraints

$$
x_{0 t}=\theta_{t} M_{1 t}^{y}+S_{1 t}^{y}
$$

\footnotetext{
${ }^{69}$ Following the Diamond-Dybvig tradition, constraint (19) could be motivated as necessary to prevent sunspotbased runs on the exchange bank. Runs can occur since types are unobservable and unconstrained agents can always obtain the special good abroad.
} 


$$
\begin{gathered}
\theta_{t+1} M_{1 t}^{y}+S_{1 t}^{y} \geq c_{1, t+1} \\
M_{t}^{y} \geq p_{t} f_{2 t}
\end{gathered}
$$

Steady-state optimality conditions for foreign agents reduce to

$$
(1 / 2)\left(\beta \sigma u^{\prime}\left(\sigma f_{2}\right)+u^{\prime}\left(f_{2}\right)\right)=\sigma
$$

In addition, it can be shown that a young foreign agent will always liquidate his silver earnings for money. If he is unconstrained, he will spend this money to purchase the special good; if he is constrained, he will trade it the following year to obtain silver to purchase the general good.

Condition (24) implicitly defines a function $\sigma=g\left(f_{2}\right)$ where $g$ can be shown to be strictly decreasing and strictly convex for coefficient of relative risk aversion $\rho \in(0,1)$. The inverse demand curve for special goods $\sigma\left(f_{2}\right)$ is then given by

$$
\sigma\left(f_{2}\right)=\left\{\begin{array}{c}
1, \text { for } f_{2}<1, \\
g\left(f_{2}\right), \text { for } f_{2} \geq 1 .
\end{array} .\right.
$$

The kink in the inverse demand curve occurs because the domestic silver-equivalent price for the special good cannot exceed the world price of unity. Domestic agents' total revenue from special good sales can then be expressed as

$$
\operatorname{TR}\left(f_{2}\right)=f_{2} \sigma\left(f_{2}\right)
$$

which can be shown to be strictly increasing and concave (strictly for $f_{2}>1$ ).

A domestic agent in the decentralized economy maximizes his objective (6) subject to stage 1a, stage $1 \mathrm{~b}$, and stage 2 budget constraints

$$
\begin{gathered}
S_{2, t-1}^{d}+\theta_{t} M_{2, t-1}^{d} \geq S_{1 t}^{d}+\theta_{t} M_{1 t}^{d} \\
S_{1 t}^{d} \geq d_{1 t}+S_{2 t}^{d} \\
M_{1 t}^{d}+p_{t} x_{1 t} \geq M_{2 t}^{d}
\end{gathered}
$$

over $d_{1 t}, x_{1 t}, S_{1 t}^{d}, S_{2 t}^{d}, M_{1 t}^{d}, M_{2 t}^{d}$ where $M_{i t}^{d}$ denotes the agent's money holdings at the end of stage $i$ of period $t$. Production decisions $x_{1 t}$ are made cooperatively, i.e., production is set so as to maximize monopoly profits. Steady-state first-order conditions for domestic agents reduce to

$$
x_{1}=\left\{\begin{array}{c}
1, \text { if } T R^{\prime}(1)<a / \beta \\
{\left[T R^{\prime}\right]^{-1}(a / \beta), \text { if } T R^{\prime}(1) \geq a / \beta}
\end{array}\right.
$$


where $T R^{\prime}$ is the right derivative of $T R$. That is, the coalition of domestic agents sets marginal revenue $T R^{\prime}$ from its sales of the special good equal to marginal cost (where the latter is adjusted for the time cost of money), if this cost is sufficiently low. Otherwise, domestic agents produce just enough of the special good to equate its silver-equivalent price in Amsterdam to the world price.

A steady-state monetary equilibrium is an allocation, combined with a set of per-capita money holdings $M_{1}^{y}, M_{1}^{d}, M_{2}^{d}$, and prices $p$ and $\theta\left(=\theta_{1}=\theta_{2}\right)$, for which (a) first-order conditions (24) and (30) hold, and (b) markets clear. Money market clearing in particular requires

$$
M_{2}^{d}=M_{1}^{y}+M_{1}^{d},
$$

i.e., that sales of money by domestic agents $M_{2}^{d}-M_{1}^{d}$ plus sales by old foreigners $M_{1}^{y}$ equal purchases by young foreigners $2 M_{1}^{y}$. Equilibria are described as

Proposition 1 . There is a continuum of steady-state monetary equilibria where

(1) Allocations, the silver-equivalent price of special goods $\sigma=\theta p$, and the real stock of bank money are the same in every equilibrium;

(2) The price of money and the money price of special goods are indeterminate in the intervals $\theta \in[\underline{\theta}, 1], p \in\left[\sigma, \frac{\sigma}{\underline{\theta}}\right]$;

(3) The nominal money stock varies with $\theta$ the according to

$$
M=d_{1} / \theta
$$

where $d_{1}$ is the equilibrium consumption of the general good by domestic agents;

(4) Money is held exclusively by foreigners over the summer, and by domestic agents and old foreigners over the winter

$$
M_{2}^{d}=M_{1}^{y}=M ; M_{1}^{d}=0 ;
$$

(5) Neither domestic nor foreign agents store silver over the winter

$$
S_{2}^{d}=S_{1}^{y}=S_{1}^{o}=0 ;
$$

(6) The exchange bank stores sufficient silver to satisfy its liquidity constraint (20)

$$
S_{1}^{b}=S_{2}^{b}=\delta \underline{\theta} M=\delta(\underline{\theta} / \theta) d_{1} .
$$


Proof (Sketch). There are two cases to consider.

Case 1: $T R^{\prime}(1)<a / \beta$. In this case the equilibrium allocation can be derived as follows: from (30), domestic agents produce just enough special goods to satisfy demand at the world silverequivalent price of one, so $\sigma=1$. From inverse demand (25) and market clearing, it follows that $d_{1}=f_{2}=1$. Using budget constraints (21) and (23), it follows that $c_{1}=1$.

The rest of the equilibrium is then constructed as follows. Absence of arbitrage in the money market requires $\theta \in[\underline{\theta}, 1]$; hence if $\sigma$ is determined it must be the case that $p \in\left[\sigma, \frac{\sigma}{\underline{\theta}}\right]$. For domestic agents, holding silver over the summer is clearly dominated by consumption, hence their summer money holdings are zero. All winter asset holdings by domestic agents then take the form of money as in (32), and in equilibrium this must equal money expenditure by the unconstrained foreign agents as in (33).

Case 2: $T R^{\prime}(1) \geq a / \beta$. In this case, from (30), domestic agents optimally produce $x_{2}{ }^{*}=\left[T R^{\prime}\right]^{-1}(a / \beta)$, hence $f_{2}=f_{2}^{*}=x_{2} *$ from market clearing. Then from inverse demand (25), $\sigma=\sigma^{*}=\sigma\left(f_{2}^{*}\right)<1$; using budget constraints (21)-(23) and (27)-(29), and market clearing, it follows that $c_{1}=d_{1}=d_{1}{ }^{*}=f_{2}^{*} \sigma\left(f_{2}^{*}\right)=\operatorname{TR}\left(f_{2}^{*}\right)$. The rest of the equilibrium is constructed as in the previous case.

Corollary. Any steady-state monetary equilibrium in the decentralized economy is inefficient.

Proof. In case 1, the equilibrium domestic agents' general good consumption $d_{1}$ and foreign agents' general good consumption $c_{1}$ is in the set of planner's allocations described by (14)-(18). However, monopoly pricing by domestic agents causes the foreign agents' consumption of the special good $f_{2}$ to fall below its efficient value.

In case 2, foreign agents again underconsume the special good relative to the planner's allocation due to monopoly pricing. Since foreign agents' general good consumption (=domestic agents' consumption $=T R$ ) is greater than one in this case, it follows that foreign agents also overconsume the general good. 
In both cases, the relative price of the special good is higher than the corresponding shadow price $a$ in the planner's allocation. Also, in both cases the bank inefficiently stores silver over the winter as backing for agents' money holdings, needed to fund next summer's purchases of general goods.

\section{Discussion}

The steady-state monetary equilibrium mimics some features of the pre-1683 situation in Amsterdam. Coin (silver) is traded for money and money for goods. The equilibrium stock of bank money is constant over the trading "year" and its value lies anywhere between the bank's purchase price and sale price. The nominal stock of money can vary somewhat across steady states. Essentially the economy functions on a "silver in advance" basis, i.e., trading in the domestic market proceeds as if domestic goods were traded for silver at price $\sigma=p \theta$.

The inefficiency of the monetary equilibrium stems from three sources. The first source of inefficiency is simply the deadweight cost of the silver $S_{1}^{b}$ necessary to support the exchange bank arrangement which, from (35), is decreasing in the market value of money $\theta$. The second source is the credit constraint on domestic agents, who must finance their stage 1 consumption from their previous year's earnings. The final source of inefficiency is the monopoly pricing undertaken by the domestic agents. The Corollary states that in equilibrium, these latter two factors in combination lead to an inefficiently high relative price and diminished consumption of the special good. Consumption of the general good may also be inefficiently subsidized.

\section{Monetary steady states with receipts}

A receipt system is now introduced into the model. Specifically, suppose that in addition to its previous activities, the exchange bank is willing to issue receipts against deposited silver. The receipt allows its holder to purchase the deposited amount of silver, at the price of $\bar{\theta}=1 .^{70}$

Under the receipt system, a foreign agent arriving in Amsterdam in stage 1 may sell silver in two ways: (1) directly trade silver for bank funds, or (2) deposit the silver into the exchange bank, thereby obtaining access to bank funds (at the bank's purchase price $\bar{\theta}=1$ units of silver per florin) and a receipt, which can be sold for additional bank funds. The market value of the receipt in stage 1a of period $t$ is $\lambda_{t}$ florins. Absence of arbitrage requires

\footnotetext{
${ }^{70}$ For algebraic transparency, we ignore the small fees that were charged to redeem a receipt.
} 


$$
\theta_{t}=\frac{1}{1+\lambda_{t}},
$$

Under (36), a foreign agent is indifferent between trading silver on the open market and trading receipts on deposited silver. Below we consider equilibria where an indifferent agent always chooses to deposit his silver and sell receipts against some portion of it. Let $D_{1}$ denote the amount of silver deposited by a foreign agent in stage 1 , and let $L_{1}$ denote the quantity of receipts sold by the agent in stage 1 trading. When silver is traded exclusively as receipts, clearing in the stage 1a silver market requires that

$$
M_{2}^{d}=(1+\lambda) L_{1}
$$

i.e., money held by domestic agents must cover the cost of redeeming deposited coin at full value $(\bar{\theta}=1)$ plus the cost of the receipts necessary for redemption.

Using (36), it is then straightforward to show that foreign agents' first-order condition (24) is exactly as in the previous model. The domestic agents' optimization problem is also unchanged from the earlier analysis; in particular, condition (30) is identical with the no-receipt case.

A steady-state monetary equilibrium with receipts consists of, in addition to the list of quantities for a monetary equilibrium without receipts, a quantity of stage 1 deposits $D_{1}$ and of receipts $L_{1}$, and a money price of receipts $\lambda$ such that conditions (24) and (30) hold and markets clear. From the foregoing discussion we have

Proposition 2. With receipts, there is a continuum of steady-state equilibria; each equilibrium is identical to an equilibrium with receipts, except in the following details:

(1) The money price of receipts $\lambda$ is indeterminate in the interval $\left(0, \underline{\theta}^{-1}-1\right)$, where the implied silver value of money $\theta=1 /(1+\lambda)$ and the money price of domestic goods $p$ fall in the same ranges as in Proposition 1;

(2) Period 1 deposits of foreign agents are $D_{1}=c_{1}$;

(3) Period 1 receipt sales of foreign agents are

$$
L_{1}=\theta M_{2}^{d}=d_{1} ;
$$

\section{Discussion}


Proposition 2 indicates that (absent aggregate liquidity shocks) the introduction of the receipt system would not in of itself have changed real allocations in the Amsterdam money markets. The value of bank money remains indeterminate and the inefficiency of the monetary equilibrium persists.

There is however a substantive difference between the equilibria described in Propositions 1 and 2 . If bank money cannot be redeemed without a receipt, then following the money market trades in stage 1a, the value of claims on the banks' stock of silver would have also been reduced relative to the no-receipt case. This would have expanded the scope for the bank's credit activities.

\section{Lending operations before receipts}

In practice the operation of the AWB incurred costs, which were offset through earnings on its loans. These elements are now introduced into the model.

Momentarily assume that the bank has access to sufficient capital so that its liquidity constraints are not binding. The annual operating cost of the exchange bank is $\gamma>0$, which is expressed in silver terms. The bank obtains silver by trading money for silver in the stage 1 markets at price $\theta$. This money is earned through loans to domestic agents in stage 1, which are repaid at stage 2. Domestic agents may borrow up to $q_{t} B_{t}$ florins, where $q$ is the bank's discount and

$$
\mathrm{B}_{t} \leq \ell p_{t} x_{1 t}
$$

for $\ell \in(0,1)$, i.e., a domestic agent can borrow at most a fraction $\ell$ of his anticipated autumn special goods sales. The bank's breakeven constraint is

$$
\theta_{t}\left(1-q_{t}\right) B_{t-1} \geq \gamma
$$

The bank does not seek to maximize profits from lending, but simply sets $q$ to recover costs. Domestic agents' budget constraints (27) and (29) are replaced with

$$
\begin{gathered}
S_{2, t-1}^{d}+\theta_{t}\left(M_{2, t-1}^{d}+q_{t} B_{t}\right) \geq S_{1 t}^{d}+\theta_{t} M_{1 t}^{d} \\
M_{1 t}^{d}+p_{t} x_{1 t} \geq M_{2 t}^{d}+B_{t}
\end{gathered}
$$

For a favorable discount $(q>\beta)$, a domestic agent will borrow as much as possible and borrowing constraint (39) will bind. In this case the domestic agents' first-order condition (30) becomes 


$$
x_{1}=\left\{\begin{array}{c}
1, \text { if } T R^{\prime}(1)<a / \beta^{*} \\
{\left[T R^{\prime}\right]^{-1}\left(a / \beta^{*}\right), \text { if } T R^{\prime}(1) \geq a / \beta^{*}}
\end{array}\right.
$$

where $\beta^{*}=\beta^{*}(\ell)=q \ell+\beta(1-\ell)>\beta$. The foreign agents' problem does not change. Effectively, the availability of credit lowers domestic agents' marginal cost of producing special goods from $a / \beta$ to $a / \beta^{*}$. An equilibrium in this case must satisfy (43) as well as the foreign agents' firstorder condition and (24). Equilibria are described as

Proposition 3. For operating costs $\gamma>0$ sufficiently small, there is a continuum of steady-state monetary equilibria with exchange bank lending where

(1) Allocations, the silver-equivalent price of special goods $\sigma=\theta p$, and the real stock of bank money are the same in every equilibrium;

(2) The price of money and the money price of special goods are indeterminate as in Proposition 1;

(3) The summer (end of period 1) nominal money stock varies with $\theta$ the according to

$$
M=d_{1} / \theta
$$

where $d_{1}$ is the equilibrium consumption of the general good by domestic agents;

(4) Money is held exclusively by foreigners over the summer and domestic agents over the winter

$$
M_{1}^{y}=M_{2}^{d}+q B=M ; M_{1}^{d}=0 ;
$$

(5) Neither domestic nor foreign agents store silver over the winter

$$
S_{2}^{d}=S_{1}^{y}=S_{1}^{o}=0
$$

(6) The exchange bank stores sufficient silver to satisfy its liquidity constraint (20)

$$
S_{1}^{b}=S_{2}^{b}=\delta \underline{\theta} M=\delta(\underline{\theta} / \theta) d_{1} .
$$

Proof. Since only the domestic agents' first-order condition (43) is modified from the previous cases, proof is by the same arguments.

Does lending by the exchange bank improve welfare? To answer this question, one must consider the capital costs of the bank's lending program. If lending leads to an increase in consump- 
tion by domestic agents $d_{1}$, then from (20) the bank must hold additional capital to maintain its liquidity. As a reference case, imagine that bank's stock of silver is obtained through a one-time, lump-sum tax on domestic agents only. ${ }^{71}$ The following result then applies.

Corollary. The monetary equilibrium with lending is inefficient. However, for operating costs $\gamma>0$ sufficiently small, there is some equilibrium with lending that dominates the monetary equilibrium without lending.

Proof. Inefficiency of the equilibrium with lending follows from the same arguments as in Proposition 1.

We now compare equilibria with lending to the equilibrium without. Again two cases must be considered. We consider the effects of a vanishingly small amount of lending (a small increase in the credit limit $\ell$ over $\ell=0$ ).

Case 1. $T R^{\prime}(1)<a / \beta$. The silver-equivalent price of special goods $\sigma$ is equal to 1 for both the equilibrium with lending and the equilibrium without. In this case, allocations are same in both equilibria, but domestic agents produce at (effectively) a lower unit $\operatorname{cost}\left(=a / \beta^{*}\right.$ with lending compared to $a / \beta$ without). Thus, with lending, domestic agents' utility increases and the exchange bank need hold no additional silver in order to satisfy its liquidity constraint. Foreign agents' utility is unaffected. Hence lending dominates for this case.

Case 2. $T R^{\prime}(1) \geq a / \beta$. The silver equivalent price of special goods $\sigma$ is less than 1 in the equilibrium without lending. Then it is straightforward to show introducing lending causes both a decrease in $\sigma$ and an increase in foreign agents' utility.

Now consider the steady-state utility of domestic agents. Using (6) this is

$$
d_{1}-a f_{2}-(1-\beta) S_{b}
$$

when the bank's silver holdings $S_{b}$ are financed by a lump-sum levy on domestic agents. Using (43) and (47) rewrite expression (48) as

$$
[1-(1-\beta) \delta(\underline{\theta} / \theta)] T R\left(\left[T R^{\prime}\right]^{-1}\left(a / \beta^{*}\right)\right)-\left[T R^{\prime}\right]^{-1}\left(a / \beta^{*}\right) .
$$

\footnotetext{
${ }^{71}$ I.e., direct taxation of foreign agents is not possible. As discussed previously, in practice the bank's capital derived at least partly from accumulated profits on lending. Obtaining capital in this way would have imposed additional costs beyond the costs of the lump-sum levy considered here, but also would have shifted some of the bank's capital costs to foreigners.
} 
The derivative of (49) with respect to $\ell$ is

$$
-(q-\beta)\left[1-(1-\beta) \delta(\underline{\theta} / \theta)-\beta^{*}\right]\left(\frac{a}{\beta^{*}}\right)^{2}\left(\left[T R^{\prime}\right]^{-1}\right)^{\prime}\left(\frac{a}{\beta^{*}}\right)
$$

whose sign varies as the sign of

$$
1-(1-\beta) \delta(\underline{\theta} / \theta)-\beta^{*} .
$$

As $\gamma \rightarrow 0$ and $q \rightarrow 1,(51)$ is positive iff

$$
1-\ell>\delta(\underline{\theta} / \theta)
$$

and, since $\delta(\underline{\theta} / \theta)<1$, condition (52) must hold for $\ell>0$ sufficiently small. In words, domestic agents' utility is increased if lending is slightly increased from zero. Note, however, sufficiently large increases in lending $\ell$ may decrease domestic agents' utility.

\section{Discussion}

The corollary to Proposition 3 shows that lending by the AWB could have increased welfare even with a liquidity requirement such as (20). The need for substantial backing of bank money would have imposed limits on the bank's lending however. Beyond a certain point, the extra profit obtained by increasing loans to domestic agents would have been outstripped by the attendant liquidity costs. From condition (52), the liquidity constraint could have been made less binding only by lowering either the bank's "bid price" for bank money $\underline{\theta}$ or its liquidity "comfort factor" $\delta$.

From the domestic agents' point of view, monopoly profits on sales of special goods would have been the necessary ingredient for their support of the banks' lending operations. With competitive pricing of the special good, lending would have provided no benefit to domestic agents and no incentive to support this activity.

\section{Lending operations with receipts}

We now consider in more detail how the introduction of receipts would have impacted the bank's liquidity constraints. In the pre-receipt equilibrium with lending, the year- $t$, beginning-ofstage 1a (after foreign agents arrive in Amsterdam but before trading) balance sheet of the bank is 


\begin{tabular}{|l|l|}
\hline \multicolumn{1}{|c|}{$\begin{array}{c}\text { Table 2: Bank's balance sheet } \\
\text { (beginning of stage 1, without receipts) }\end{array}$} \\
\hline Assets $\quad$ Liabilities + NW \\
\hline Silver $S_{2, t-1}^{b}$ & Balances $M$ \\
$\begin{array}{l}\text { Loans to domestic } \\
\text { agents } B\end{array}$ & NW \\
\hline
\end{tabular}

and the bank's liquidity constraint would be given by (20), i.e., $S_{b, t-1}^{2} \geq \delta \underline{\theta} M$. After stage 1 trading (beginning of stage 2) is complete, the bank's balance sheet is

\begin{tabular}{|l|l|}
\hline \multicolumn{1}{|c|}{$\begin{array}{c}\text { Table 3: Bank's balance sheet } \\
\text { (beginning of stage 2, without receipts) }\end{array}$} \\
\hline Assets $\quad$ Liabilities + NW \\
\hline Silver $S_{1, t}^{b}$ & Balances $M$ \\
$\begin{array}{l}\text { Loans to domestic } \\
\text { agents } B\end{array}$ & NW \\
\hline
\end{tabular}

and the liquidity constraint is $S_{1, t}^{b} \geq \delta \underline{\theta} M$. Since $S_{1, t}^{b}=S_{2, t-1}^{b}$ in equilibrium, the bank's liquidity constraint does not change from stage 1 to stage 2 . After stage 2 trading is complete and loans are repaid, the bank's balance sheet is

\begin{tabular}{|l|l|}
\hline \multicolumn{2}{|c|}{$\begin{array}{c}\text { Table 4: Bank's balance sheet } \\
\text { (end of stage 2, without receipts) }\end{array}$} \\
\hline Assets & Liabilities + NW \\
\hline Silver $S_{2, t}^{b}$ & Balances $M_{2}^{d}$ \\
& NW \\
\hline
\end{tabular}

The liquidity constraint at this stage is $S_{2, t}^{b} \geq \delta \underline{\theta} M_{2}^{d}$, which, since $S_{2, t}^{b}=S_{1, t}^{b}$ in equilibrium, is implied by the previous liquidity constraints. 
Now consider the bank's balance sheets at the same stages under the receipt system. At the beginning of money market trading stage 1a, the bank's balance sheet is

\begin{tabular}{|l|l|}
\hline \multicolumn{2}{|c|}{$\begin{array}{c}\text { Table 5: Bank's balance sheet } \\
\text { (beginning of stage 1, with receipts) }\end{array}$} \\
\hline Assets & \multicolumn{1}{|c|}{ Liabilities + NW } \\
\hline Silver $S_{2, t-1}^{b}+D_{1}$ & $\begin{array}{l}\text { Balances } M \text { of domestic agents } \\
\text { Balances } D_{1} \text { of foreign agents } \\
\text { Lof which } D_{1} \text { redeemable on demand] }\end{array}$ \\
& NW domestic agents $B$ \\
\hline
\end{tabular}

If the bank is only committed to pay coin against all outstanding receipts, its liquidity constraint is

$$
S_{2, t-1}^{b}+D_{1}-L_{1} \geq D_{1}-L_{1}
$$

or simply

$$
S_{2, t-1}^{b}+L_{1} \geq 0
$$

Following stage 1 trading, the bank's balance sheet is

\begin{tabular}{|l|l|}
\hline \multicolumn{2}{|c|}{$\begin{array}{c}\text { Table 6: Bank's balance sheet } \\
\text { (beginning of stage 2, with receipts) }\end{array}$} \\
\hline Assets & Liabilities + NW \\
\hline Silver $S_{1, t}^{b}=S_{2, t-1}^{b}+D_{1}-L_{1}$ & $\begin{array}{l}\text { Balances } D_{1}+\lambda L_{1} \text { of foreign agents } \\
{\left[D_{1}-L_{1} \text { redeemable on demand }\right]}\end{array}$ \\
Loans to domestic agents $B$ & NW \\
\hline
\end{tabular}

If the bank is committed to pay coin against all outstanding receipts, its liquidity constraint is

$$
S_{2, t-1}^{b}+D_{1}-L_{1} \geq D_{1}-L_{1}
$$

or 


$$
S_{2, t-1}^{b} \geq 0
$$

Finally, after stage 2 trading is complete, the bank's balance sheet contracts to

\begin{tabular}{|l|l|}
\hline \multicolumn{2}{|c|}{$\begin{array}{l}\text { Table 7: Bank's balance sheet } \\
\text { (end of stage 2, with receipts) }\end{array}$} \\
\hline Assets & Liabilities + NW \\
\hline Silver $S_{2, t}^{b}=S_{2, t-1}^{b}$ & Balances $M_{2}^{d}$ \\
& NW \\
\hline
\end{tabular}

Since all receipts have been redeemed by this point, there is no liquidity constraint on the bank.

To summarize, these calculations indicate that under the receipt system, an expansion of the bank's lending $B$ need not be backed by an expansion of its silver holdings $S^{b}$, essentially because, under receipts, the bank's liquidity constraint is slackened from (47) (in its equilibrium form) to (56). Indeed, in the steady-state world analyzed here, it is conceivable that the bank holds no silver over the winter. To avoid indeterminacy of the silver price of money $\theta$ in particular, however, we assume that the bank must commit (off-equilibrium) to sell silver (i.e., receipts) at its target price, and possess "enough" silver $\underline{S}>0$ to back this pledge.

This does not explain how large $\underline{S}$ must be to guarantee determinacy. As a benchmark for the comparisons below, we take $\underline{S}$ to be the value of $S_{2}^{b}$ necessary to support the monetary equilibrium without lending, i.e., $\underline{S}=S_{2}^{b}$ as specified in (35).

Our last set of results confirms agents' preferences for the receipts arrangement:

Proposition 4. With receipts, the monetary equilibrium with lending $\ell$ is identical to the equilibrium given in Proposition 3, except that the bank's winter silver stock $S_{2}^{b}$ is reduced to $\underline{S}$.

Proof. As in Proposition 2, optimality conditions and market clearing are not affected by the introduction of receipts. 
Corollary 1. For a given credit limit parameter $\ell$, the equilibrium with receipts dominates the equilibrium without receipts.

Proof. Decreasing the bank's winter silver holdings (as occurs with the introduction of receipts) does not change allocations of consumption goods, and lowers the deadweight loss.

Corollary 2. Under receipts, welfare is increasing in $\ell$.

Proof. With receipts, an expansion of lending $\ell$ does not result in an increase in the bank's winter silver holdings $S_{b}^{2}$. From (47), the bank's summer silver stock $S_{1}^{b}$ increases but this is occurs through voluntary deposits by foreign agents; domestic agents bear no additional liquidity cost. Hence this cost does not enter into welfare comparisons.

Increasing $\ell$ increases domestic agents' welfare increases because, from (43), this lowers their marginal costs of production, while their marginal revenue from special good sales remains the same.

Foreign agents' welfare increases as in Proposition 3; hence, total welfare increases. 